\title{
Os animais do Brasil no relato do jesuíta Gaspar Afonso sobre a viagem da nau "São Francisco" (1596)
}

\author{
Dante Martins Teixeira ${ }^{1}$ \& Nelson Papavero ${ }^{2}$
}

${ }^{1}$ Universidade Federal do Rio de Janeiro (UFRJ), Museu Nacional. Rio de Janeiro, RJ, Brasil. E-mail: dante.teixeira@pq.cnpq.br

${ }^{2}$ Universidade de São Paulo (USP), Museu de Zoologia (MZUSP). São Paulo, SP, Brasil.

Pesquisador Sênior do Conselho Nacional de Desenvolvimento Científico e Tecnológico (CNPq).

E-mail: pavotnel@gmail.com

\begin{abstract}
Upon Vasco da Gamas's return from India (1499), Portugal tried to consolidate the recently-discovered route to the East Indies, launching a second fleet commanded by Pedro Álvares Cabral, that would come back to the kingdom in July 1501 after a troubled series of well-known events. Soon afterwards, a maritime connection between Lisbon and India would be articulated - the famous "Carreira da India", which would last four hundred years, involving hundreds of ships. However, only a few of those vessels would land in the Brazilian coast, as the "Carreira da India" was conceived as a direct, non-stop liaison between Lisbon and the East. Very few elements of the Brazilian fauna are mentioned in the accounts about this trade route, and the Jesuit Gaspar Afonso description on the voyage of the Portuguese ship "São Francisco" (1596) is particularly noteworthy in this sense. A total of 19 animals are mentioned, including one insect, three reptiles, three birds, five fish and seven mammals. Although not at all related to Brazil, it must be emphasized Gaspar Afonso's register of an observation made by his confrere Fulgêncio Freire - perhaps one of the first notices known about an African anthropoid.
\end{abstract}

Key-Words. Carreira da India; Gaspar Afonso; Colonial Trade; 16th Century; Colonial Brazil; History of Zoology; Fauna; Primate; Anthropoid.

\begin{abstract}
Resumo. Com o retorno de Vasco da Gama em 1499, Portugal buscaria consolidar o recém-descoberto caminho-marítimo para as Índias lançando ao mar uma segunda esquadra comandada por Pedro Álvares Cabral, a qual retornaria ao reino em julho de 1501 após uma atribulada série de eventos bem conhecidos. Logo em seguida, seria articulada uma conexão marítima entre Lisboa e a Índia sob a forma de viagens anuais, a célebre "Carreira da Índia", que perduraria por quatrocentos anos e envolveria centenas de embarcações. Entretanto, pouquíssimas dessas naus aportariam em nosso litoral, pois a "Carreira da Índia" foi concebida como uma ligação direta quase sem escalas entre Lisboa e o Oriente. Entre os esparsos testemunhos sobre a fauna exótica encontrados nesse universo documental, o do jesuíta Gaspar Afonso é um dos mais interessantes, relatando viagem da nau "São Francisco" em 1596. Ao todo, seriam mencionadas 19 espécies geralmente atribuídas à fauna brasileira, elenco formado por um inseto, três répteis, três aves, cinco peixes e sete mamíferos. Embora não diga respeito ao nosso país, chama a atenção o fato desse religioso ter registrado uma observação de seu confrade Fulgêncio Freire que pode eventualmente constituir uma das primeiras notícias conhecidas até 0 momento de um antropóide africano.
\end{abstract}

Palavras-Chave. Carreira da Índia; Gaspar Afonso; Fulgêncio Freire; Comércio Colonial; Século XVI; Brasil Colônia; História da Zoologia; Fauna; Primata; Antropóide.

\section{INTRODUÇÃO}

Com o retorno de Vasco da Gama em 1499, Portugal buscaria consolidar o recém-descoberto caminho-marítimo para as Índias lançando ao mar uma segunda esquadra comandada por Pedro Álvares Cabral, a qual retornaria ao reino em julho de 1501 após uma atribulada série de eventos bem conhecidos. Logo em seguida, seria articulada uma conexão marítima entre Lisboa e a Índia - mais especificamente para Goa, cidade conquistada pelo governador Afonso de Albuquerque em 1510 $10^{1}$

Entre 1509 e 1515, Afonso de Albuquerque ocuparia 0 cargo de governador do Estado Português da Índia, o qual havia sido criado já em 1505. No ano de 1530, sua sede passou de Cochim para Goa por decisão do governador Nuno da Cunha (Amado, 1994; Boxer, 1969; Junqueiro, 1994; Thomaz, 1994). 
sob a forma de viagens anuais, a célebre "Carreira da Índia", destinada a perdurar quatrocentos anos e envolver centenas de embarcações ${ }^{2}$.

Deixando Lisboa entre o final de inverno e o começo da primavera do hemisfério norte, os navios tomavam rumo do arquipélago de Cabo Verde, de onde viravam para o sudoeste a fim de contornar o anticiclone do Atlântico Sul - a chamada "volta do Brasil" ou "volta do mar" - e dirigir-se para o cabo da Boa Esperança. Vencido esse obstáculo, costumavam fazer escala em Moçambique e velejavam para a Índia a favor dos ventos das monções de verão (julho-agosto), tendo de invernar na África caso chegassem demasiado tarde. Em seu retorno à Europa, as embarcações aproveitavam as monções de inverno (dezembro-janeiro) para fazer a rota inversa em direção ao cabo da Boa Esperança, seguindo depois para as ilhas de Ascensão e Santa Helena até ao norte do arquipélago de Cabo Verde, quando iniciavam a chamada "volta pelo largo" que as levaria para o arquipélago dos Açores e daí para Portugal. Em média, as naus tardavam cerca de um ano e meio para completar sua viagem, gastando em torno de seis meses de navegação de Portugal até a Índia - e vice-versa ${ }^{3}$.

Tendo o tráfico de especiarias como objetivo central, a "Carreira da Índia" do século XVI foi concebida como uma ligação direta quase sem escalas entre Lisboa e o Oriente, estratégia que buscava acelerar o fluxo de mercadorias e reduzir os custos com as tripulações. Semelhante política encontra-se explicitada na "Provisão de Navegação" de 6 de março de 1565, segundo a qual os navios porventura impedidos de prosseguir para a Índia estavam proibidos de invernar no Brasil, devendo retornar a Lisboa e assim evitar deserções e danos, bem como as "grandes despesas", "sem nenhuma utilidade" com os soldos e os mantimentos destinados ao pessoal de bordo ${ }^{4}$. Graças a essas determinações, pouquíssimas naus da "Carreira da Índia" teriam de fato aportado no litoral brasileiro, quadro destinado a mudar posteriormente. Descartadas as 12 velas da esquadra comandada por Pedro Álvares Cabral, não mais de 24 embarcações teriam se detido em nosso país entre 1500 e 1598, elenco que inclui as quatro naves da frota de Afonso de Albuquerque (1503) e as seis comandadas por Dom Pedro da Silva da Gama (1537) 5 . Não obstante, seria pertinente reunir os esparsos testemunhos acerca da natureza brasileira encontrados no

2 Sobre a natureza, capacidade e outros detalhes relativos às embarcações, aos capitães e ao próprio tráfico da "Carreira da Índia", vide Albuquerque (1978, 1994); Barata (1968, 1970); Barata et al. (1975); Boxer (1961, 1969, 1971); Domingues (1994a, 1994b, 1994c, 2006); Domingues \& Guerreiro (1988); Godinho (1963-1965); Guinote et al. (1998); Lacerda (2006); Leitão \& Lopes (1974); Morais (1941); Ramos (2013) e Vasconcelos (1941).

3 Vide Albuquerque $(1978,1994)$; Boxer $(1961,1971)$ e Matos (1988). Determinadas fontes afirmam ser comum que os navios da armada se dispersassem na tentativa de chegar primeiro à Índia e assim vender sua carga pelo melhor preço, decisão arriscada que podia trazer sérias consequências (vide Gaspar Afonso in B.G. de Brito, 1735-1736).

4 Datado de 5 de março de 1505, o chamado "Regimento do Capitão-Mor Dom Francisco de Almeida" demonstra que a escala no Brasil seria permitida no começo do século XVI, situação que mudaria radicalmente com a "Provisão de Navegação" de 6 de março de 1565 (in Rego \& Baxter, 1962 e Mendonça, 1972). Vide também Albuquerque (1994); Boxer (1961) e Matos (1988).

5 Vide Boxer (1961, 1971); Lapa (1968) e Marchant (1941). Como a nau de Vasco de Ataíde teria desaparecido na altura do arquipélago de Cabo Verde, a frota de Cabral chegaria ao Brasil com apenas 12 navios. universo documental referente à "Carreira da Índia" e tecer os devidos comentários sobre a parte zoológica, uma abordagem que permanece virtualmente inédita até os dias de hoje. Desse ponto de vista, um dos relatos mais interessantes pertence ao jesuíta Gaspar Afonso sobre a viagem da nau "São Francisco", que esteve no Brasil em meados de 1596.

\section{A VIAGEM DA NAU "SÃO FRANCISCO" E O TEXTO DO JESUÍTA GASPAR AFONSO}

Muito pouco se conhece sobre Gaspar Afonso, exceto que teria nascido em Serpa, Portugal, em torno de 1548 , tendo ingressado na Companhia de Jesus no ano de 1569. Escreveu um "Tractatus usuris" e um arrazoado de "Sermões para as festas de todo ano", bem como a "Relação da viagem e sucesso que teve a nau S. Francisco em que ia por capitão Vasco da Fonseca, na armada que foi para a Índia no ano de 1596". Este seria o seu texto mais conhecido, do qual existe uma versão extensa na Biblioteca de Évora (Cod. CXVI/9-96, páginas 1 a 168) e outra mais resumida pertencente ao Archivum Romanum Societatis Jesu (Lus. 106 - Lusitania 1599 - folios 251 recto a 270 verso). Nesses documentos, Gaspar Afonso busca narrar ao Geral da ordem em Roma, Claudio Acquaviva, as peripécias de sua malograda tentativa de chegar a Índia. Tendo partido de Lisboa em 10 de abril de 1596 com oito jesuítas, a nau "São Francisco" perderia o leme antes de atingir o cabo da Boa Esperança, sendo forçada a arribar para reparos em Salvador, Bahia, onde aportou a 17 de julho desse mesmo ano. Após uma estada de "cinco meses menos quatro dias" na Bahia, Gaspar Afonso e seus confrades tentariam voltar para Portugal, mas o navio seria desviado para o Caribe graças aos ventos contrários e problemas com o novo leme. Conforme o próprio jesuíta assinala, o retorno só aconteceria após uma atribulada viagem de três anos e 19 dias. Gaspar Afonso ainda ensinaria teologia moral em Évora por quase uma década e terminaria seus dias no colégio jesuíta de Coimbra, falecendo a 21 de fevereiro de 1618.

Com algumas pequenas modificações, a variante da "Relação da viagem da nau São Francisco" depositada na Biblioteca de Évora seria trazida à luz por Bernardo Gomes de Brito no segundo tomo da famosa "História TrágicoMarítima" (1736), publicação que serviu de base para a presente análise (Figura 1 e Anexo 1$)^{6}$. Mencionados ou parcialmente transcritos em diversas ocasiões, os comentários zoológicos de Gaspar Afonso podem ser de leitura não muito fácil graças às peculiaridades do estilo adotado, além de incluir diversas citações oriundas de textos clássicos, do Livro Sagrado e de antigos escritos dos Pais da Igreja. Além disso, a identificação dos trechos sobre o

6 Grande parte das parcas informações biográficas sobre 0 jesuíta Gaspar Afonso encontra-se dispersa na vasta bibliografia disponível sobre a "História Trágico-Marítima". Sobre a obra em questão, sua natureza, seu autor e os responsáveis pelos diferentes relatos que a compõe, vide Backer \& Backer (1886); Boxer (1959, 1968); B.G. de Brito (1904, 1955, 1971, 1998); Duffy (1955); Kockel (2014); Lanciani (1979, 1984, 1997, 2006); Madeira (1999, 2005a, 2005b); Marešová (2013); Moniz (2001, 2009); Seixo \& Carvalho (1996) e Silva (1859). 


\section{HISTORIA}

TRA GICO-MAR ITIMA Em que se efcrevern chronologicamente os Naufragios que tiverao as Naos de Portugal, depois que se poz em exercicio a $\mathrm{Na}$ vegaçaõ da India.

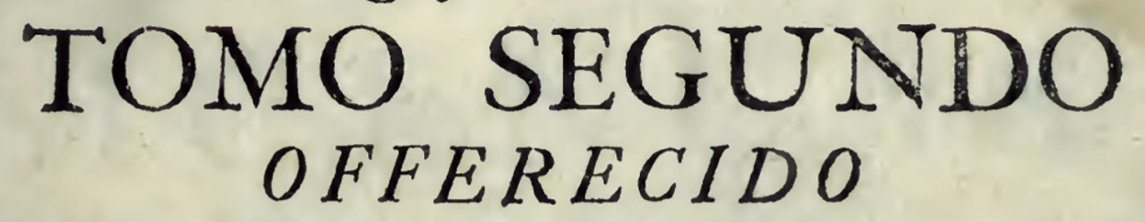

A' Augufta Mageftade do muito Alto, e muito Poderofo Rey
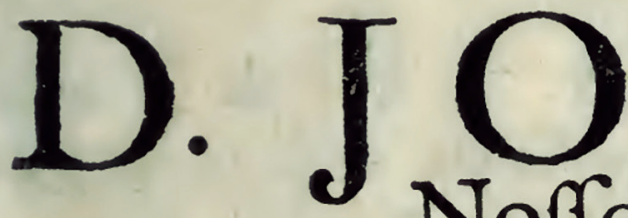

Noffo Senhor.
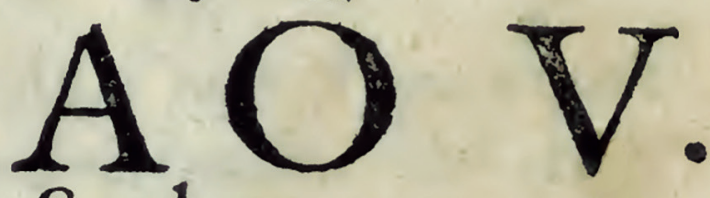

POR BERNARDO GOMES DE BRITO.

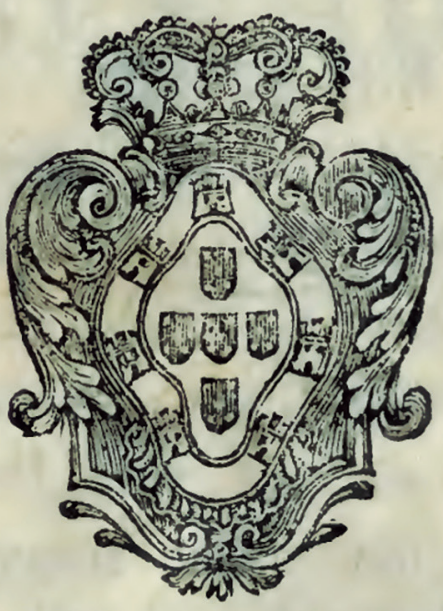

LISBOA OCCIDENTAL,

$\mathrm{Na}$ Officina da Congregaçaõ do Oratorio. M. DCC. XXXVI.

Coms todas as licenças neceffarias. 
Brasil por vezes apresenta certas dificuldades adicionais, pois existem momentos onde tais alusões, além de dispersas e rodeadas de incertezas, mostram-se muito breves e destoam do restante da sentença, caso das linhas dedicadas aos peixes observados pelo religioso em alto mar e do relato acerca dos peixes-bois encontrados em Santo Domingo, atual República Dominicana. Não deve causar surpresa, portanto, que algumas observações dedicadas aos nossos animais tenham aparentemente passado despercebidas pelos demais autores interessados, lacuna que parece justificar a publicação de um estudo mais completo 7 .

\section{Transcrição atualizada das passagens geralmente atribuídas aos animais do Brasil no texto do jesuíta Gaspar Afonso (versão da Biblioteca de Évora reproduzida na “História Trágico Marítima”, 1736)}

"Relação da viagem e sucesso que teve a nau São Francisco em que ia por capitão Vasco da Fonseca, na armada que foi para a Índia no ano de 1596, escrita pelo padre Gaspar Afonso, um dos oito da Companhia ${ }^{8}$ que nela iam

[...] Navegando, pois, assim todas as naus em conserva ${ }^{9}$ entre ambas as fortunas até passada a Linha Equinocial, sem mais outro alívio que os grandes rebanhos de peixe grande e pequeno, que de dia com grandes festas e danças seguem a nau - e com maiores e mais alegres de noite pela ardência da água e fios ou meadas de ouro ${ }^{10}$ que com ela vão fazendo por todos aqueles 47 graus, que é a distância de ambos os Trópicos onde eles, pela vizinhança do sol, se criam e andam em tão grandes manadas que é mágoa mui grande não ir em cada nau um Santo Antônio que Ihes pregasse e os doutrinas$\mathrm{se}^{11}$. Bem é verdade que sem essas pregações e doutrina andam eles por ali tão inocentes que não é necessário por-lhes isca nos anzóis, porque sem ela à porfia caem, enganados com um trapinho envolto no pé do anzol, a que se arremessam em pulos para desenfastiar da manchua $^{12}$, que é um peixinho muito miúdo que o autor da natureza por aqueles campos cria em grande abundância, como ervagem para tanto gado. A pressa com que todo este peixe corre de um lado e de outro, deixando a nau no meio, é tamanha que com a nau levar umas asas tamanhas e tão cheias de vento - e eles umas tamaninas - a deixam atrás.

7 Vide, por exemplo, Almaça (1993, 2002); Cunha (1993); França (1926); Mello-Leitão (1941, 1946, 1951); Miranda (2004) e Nomura (1996).

8 Óbvia referência à Companhia de Jesus.

9 "Fazer conserva" ou "navegar de conserva" são termos de marinharia utilizados para designar os navios que viajam em conjunto (Leitão \& Lopes, 1974).

10 Na visão de certos autores (e.g., França, 1926; Nomura, 1996), essa passagens busca descrever a luminescência produzida pelos protistas dinoflagelados pertences ao gênero Noctiluca.

11 Segundo a tradição, ao ser desprezado pelos habitantes da cidade de Rimini nos idos de 1223, Santo Antônio dirigiu-se ao rio Marechia e pregou aos peixes, um dos seus milagres mais conhecidos (Lopes, 1868).

12 Conforme 0 original. André Vaz (in Costa, 1940a) escreveria "manjua", uma "sardinha pequena que servia de alimento às aves marítimas" (vide Fonseca, 1938). As variantes "manchuva" e"manchuba" ainda são encontradas em Santa Catarina (Branco \& Rodrigues, 1998), enquanto "manjuba" é de uso geral em boa parte do litoral brasileiro.
Nestas festas que os peixes vão fazendo às naus são grandes figuras os que chamam voadores, que são de um palmo, maiores e menores. Não tem mais que duas barbatanas, as quais começam de junto à goela e vão estendidas, cada uma por seu lado, do comprimento do mesmo peixe. E como por todo o mar se acham pássaros, que de diversas ilhas por ele se espalham, quem não os conhece ainda cuida que também estes [peixes] o são. É coisa formosa e aprazível ver arrancar um bando destes subitamente avante de proa, cuidando ser aquele que dá sobre eles o leviatã que os vai tragar. Levavam de um vôo como dois tiros de pedra (ou três) ${ }^{13}$ e tão altos que alguns nos caíam dentro na nau cansados, como faziam também alguns pássaros pelos mastros e antenas, cuidando que pousavam nos arvoredos de alguma ilha, deixando-se tomar com tanta inocência sua e obediência aos homens como lhes já tiveram em outro tempo ${ }^{14}$. É esta fraca e desarmada turba de voadores perseguida no mar pelos grandes (que em toda a parte se querem manter dos pequenos) e no ar (que a natureza, quando lhes deu as asas, Ihes assinou por couto) pelas verdadeiras aves, que os desconhecem e não querem admitir nem receber tais moradores em seu elemento, nem [os] agasalhar em sua casa. E assim, fugindo os coitadinhos do fumo caem no fogo e fugindo do dente caem na unha. E o pior é que como os peixes grandes, a quem eles fugiram da boca, sabem quão fingidas são aquelas asas e quão prestes o coitadinho do Ícaro há de cair sobre as águas, o vão seguindo por baixo com tanta ligeireza e velocidade como ele voa por cima, até que derretidas as asas Ihes cai a pique na boca ${ }^{15}$.

Nem acrescentam menos prazer, por sua parte, os tubarões, peixe fero e carniceiro, os quais têm por devoção não se apartar da nau, enquanto está em calma ou corre com pouco vento, para com sua vista aliviar a moléstia dos navegantes sem quererem por seu serviço mais jornal que a comida. E esta é os jantares que sempre vão de molho a bordo presos a seus cabos para se irem descendo, os quais eles vão em torno da nau visitando e tragando sem enjeitar nenhum por salgado, salvo aquele que por boa diligência de seu dono foi alado primeiro que lhe chegassem. Para lhes fazer pagar seus contínuos roubos, rapinas e ladroíces, os tomam às vezes com uns anzóis como cambos de ferro que para isso levam, engastados em um palmo de cadeia por razão de uma serra de três ou quatro ordens de dentes que têm, tão fortes e tão agudos que servem aos brasis ${ }^{16}$ de ferros em suas flechas. Põe-se-lhes por isca tudo o que nesta vida se pode comer e o que se acha mais à mão, porque para tudo têm

13 Comum nos documentos da época, tal expressão faz referência ao alcance da boca de fogo vulgarmente conhecida como "pedreiro", variedade de morteiro capaz de disparar projéteis de pedra a uma distância de $450 \mathrm{~m}$ (Leitão \& Lopes, 1974). A avaliação de Gaspar Afonso envolve certo exagero, pois os autênticos peixes-voadores (Exocoetidae) utilizam o impulso conferido por vigorosos movimentos da cauda para sair da água com grande velocidade e planar por até $300 \mathrm{~m}$ sobre a superfície, sendo sustentados no trajeto por suas longas nadadeiras peitorais mantidas abertas e rígidas (Breder, 1938; Bruun, 1935).

14 Ou seja, antes do pecado original.

15 Encarcerados no labirinto de Creta pelo rei Minos, Dédalo e seu filho Ícaro teriam escapado voando graças a dois pares de asas construídos com penas unidas com cera. As de Ícaro se desfariam quando ele se aproximou em demasia do sol, precipitando-o no mar.

16 Isto é, os indígenas brasileiros. 
excelente estômago. E como têm a boca muito por baixo, quando há de tomar o bocado viram-se de costas para que ele mesmo lhes caia na boca. Presos eles não há mais touros $^{17}$, assim no mar como no convés, que é jogo de que eles ordinariamente servem, posto que as sortes são poucas e perigosas. E custou uma um dia bem caro a um marinheiro, a quem deixou bem ferido e enxovalhado.

Andam sempre pelo mar acompanhados de uns peixinhos muito pintados que chamam romeiros - não sei de que santos, salvo dos padroeiros das naus que vão pintados na popa, que é a primeira coisa que eles visitam. Mas porque como pobres não poderiam por si fazer estes caminhos, encostam-se aos tubarões - que Ihes vêm fazendo os gastos - sustentando-se de suas migalhas, que são muitas e grossas as que de sua mesa sempre vão caindo, por ser larga e mui abastada, Porém [o fazem] com todo o recato, porque não lhes aconteça o Dum captat, capitur ${ }^{18}$. E para esse efeito de segurança sua, nunca lhes saem das costas contrapostos à boca, que vai por baixo. E sentem-se eles tão obrigados por esta esmola (virtude própria de pobres: ser conhecidos e agradecidos) que preso ele se prendem eles, ferrados em suas costas, sem ser bastante barafustar e voltar o tubarão tanto, primeiro que o além acima, para se desaferrarem dele até dentro no convés, tendo por ato de muito primor - como é, com efeito - a quem seguiram no próspero, acompanhar também no adverso e morrer com quem viveram.

Navegando pois assim, como digo, nos começamos a apartar, como fazem todos, por razão do mesmo interesse para chegar primeiro à Índia e vender mais caro, que foi causa de ficarmos sós sem quem nos desse a mão e de se cumprir em nós ao pé da letra aquilo do Eclesiastes: Va soli quia cum ceciderit non habet sublevantem $\mathrm{se}^{19}$. E indo assim em demanda daquele grão cabo ${ }^{20}$, com pássaros dele (que chamam teijões ${ }^{21}$ ) pousados na água na esteira da nau e com a artilharia já abatida no porão ${ }^{22}$, como fazem todas as naus quando se sentem vizinhas a ele, aprestadas para lutar com seus mares e esperar a salva tormentosa com que ele faz sempre festa e saúda aos que passam com tanto estrondo. Chegando a vinte e seis graus do Sul um dia à boca da noite (ou uma noite à boca da morte), indo a nau com todas as velas dadas e elas cheias de todo o vento que podiam recolher - que não seria pouco, pois só a da gávea tinha mil e seiscentas varas, segundo o mestre me disse - e nós todos tão contentes por nos ter entrado aquela tarde o vento que desejávamos, eis que - subitamente - quebra e desaparece o leme - e sei eu, por boa via, que a causa foi deso-

17 Como "não há mais touros" deviam terminar as touradas. Nessa passagem um tanto confusa, Gaspar Afonso parece criticar 0"jogo" - mantido até data bastante recente - através do qual os marinheiros buscavam "vingar-se" dos tubarões, que eram puxados para o convés e tinham a cauda cortada ou o ventre aberto antes de serem devolvidos ao mar. Essa cruel diversão, entretanto, por vezes causava sérios ferimentos nos próprios tripulantes, atingidos pelos seláquios que se debatiam e abocanhavam às cegas.

18 Em latim no original. "Serem capturados enquanto capturam".

19 Em latim no original. "Ai de quem está sozinho, pois, quando cair, não terá quem o levante", sentença do Eclesiastes (4: 10)

20 Ou seja, o cabo da Boa Esperança.

21 "Teijoens" no original (vide Anexo 1).

22 "Abater a artilharia" significa tirá-la do convés para a coberta ou o porão, evitando assim os acidentes causados pelo seu deslocamento (vide Leitão \& Lopes, 1974). bediência pura, que no mar e na terra sempre obra semeIhantes efeitos. Já V.R. ${ }^{23}$ vê que noite aquela seria para a primeira meditação dos Novíssimos ${ }^{24}$ - não imaginando que coisa é a morte, senão vendo com os olhos sua própria figura - cujo prelúdio foi uma confissão que todos fizemos para última desta vida.

O dia seguinte - e alguns mais - se gastaram em deliberar sobre o remédio, que foram dois mastros, ou vergas $^{25}$, lançadas pela popa, a modo com que se governam os barcos de Riba do Douro. E acabado este, se gastaram outros tantos dias no acordo da derrota que se tomaria até a final resolução, que foi ir em demanda da Baía de Todos os Santos no Brasil, ainda que contra um expresso Regimento d'El Rei, porque a necessidade não tem lei $^{26}$. Tornando treze graus atrás, com temores [a] cada hora de qualquer refrega de vento, assim porque o governo era fraco, como porque dando os dois mastros que nos serviam de dois lemes - por não se poderem subjugar ainda com bonança - grandes pancadas nos calimes ${ }^{27}$, que é o [ponto] mais fraco da nau, com qualquer tensão de vento em breve espaço a abriam. Mas foi Nosso Senhor servido de nos prosperar o tempo até à boca da baía, onde estivemos tão perdidos que havia quem, com menos confiança da que à sua piedade se deve, já não pedia a Nosso Senhor que o livrasse de dar à costa, mas - já que íamos dar nela - não fosse em um recife de pedra que tínhamos por avante, mas em uma pouca de areia que perto estava, onde sequer escapássemos com as [nossas] vidas. Porém ele o fez como bom e piedoso pai, porque assim como nos tinha livrado a noite de antes (na qual, por não sabermos onde estávamos - por vir o piloto muito enfermo e haver quinze dias que não tomava o sol, nem carteava ${ }^{28}$ - íamos varar em terra) por meio de um navio, que à meia noite apareceu junto de nós e rodeou em torno a nossa nau sem querer responder às perguntas que lhe fazíamos - quem era ou que queria - até que o dando nós por ladrão e supondo que estaríamos junto da terra e perto do porto (que é paragem onde esta sorte de gente faz sempre sua vivenda e anda ganhando seu pão com pouco suor de seu rosto) nos fizemos na volta do mar para vir buscá-la de dia, como viemos, dando com ela logo à madrugada tanto de focinhos ${ }^{29}$ que fez trocar o conceito e nome de ladrão que demos ao navio - e tê-lo por anjo que nos veio a avisar e desviar do perigo em que estávamos e [do] naufrágio que poucos passos avante fazíamos. Assim agora [Nosso Senhor] nos quis também aliviar por meio de um vento súbito que de terra nos mandou, com que saímos com [a] tão pouca ajuda dos nossos dois lemes, que em chegando à vista

23 Abreviatura de "Vossa Reverendíssima". Conforme já foi mencionado, a carta era dirigida ao padre Claudio Acquaviva, que ocupou o cargo de Geral dos jesuítas entre 1581-1615.

24 A doutrina católica chama de "Novíssimos" os eventos observados após a vida: a Morte, 0 Juízo, o Inferno e o Paraíso. Dedicar-se à "primeira meditação dos Novíssimos" significa que todos estariam pensando na própria morte.

25 Peça de madeira cilindro-cônica transversal ao mastro na qual se prendem as velas.

26 Trata-se provavelmente da já mencionada "Provisão de Navegação" de 6 de março de 1565 , pela qual Dom Sebastião proíbe que os navios da "Carreira da Índia" arribassem no Brasil.

27 A parte mais estreita e frágil do casco, situada na popa entre a linha d'água e o travessão sobre o qual se movimenta a cana do leme.

28 Ou seja, não tomava a altura do sol e tampouco consultava as cartas náuticas.

29 Equivalente a "dar de cara". 


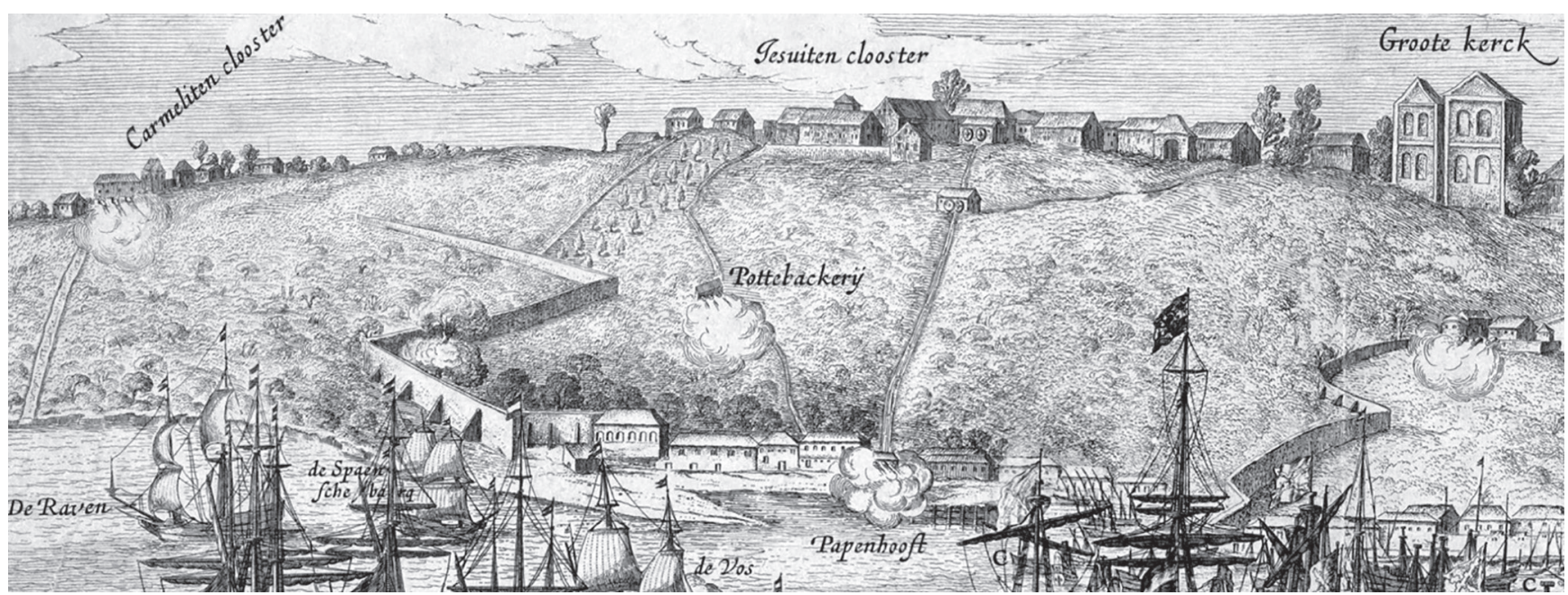

Figura 2. 0 colégio jesuíta de Salvador. Detalhe da “Vitória da frota holandesa na Baía de Todos os Santos”, gravura de Hessel Gerritsz (1627).

do nosso colégio - donde por estar alto e sobre o mar se vêem todas as naus, desde que embocam pela baía até que lançam ferro [Figura 2] ${ }^{30}$ - disse o irmão Francisco Dias (que V.R. bem conhece, o qual sobre a ciência da arquitetura, que cá [já] tinha, acrescentou a náutica com tanta perfeição que é o piloto do nosso navio em que o padre provincial visita e os irmãos se mudam de uns colégios para outros ${ }^{31}$ ) que aquilo que vinha entrando era [uma] nau da Índia sem leme.

Até aqui, nossas ocupações na nau - e depois na volta, enquanto ela deu lugar - eram confessar, dizer missa seca $^{32}$ aos domingos [e] dias santos (que nestas naus se ouve com muita devoção e consolação - e para isto as provê El Rei a todas dos ornamentos necessários), ensinar a doutrina aos meninos (que são muitos) e pregar aos grandes. Em todos estes ministérios fez muito cada um dos padres italianos, porque cada um deles tinha muito de Nosso Senhor, mostrando bem o espírito que os trazia à Índia da Itália e o ardente zelo e desejo que tinham de dá-lo a conhecer e fazer amar de todo o mundo. De onde nasceu ao padre Jacome de Vicariis ${ }^{33}$ (já que o pregar havia de ser em português e estava à conta de um só que o era) alcançar tão cedo de Nosso Senhor tal purificação - como aquela do cálculo ou carvão aceso de Isaías $^{34}$ - que em breves dias o fez e daí por diante o con-

30 Fundado por Manoel da Nóbrega em 1553, foi o primeiro colégio da Companhia no Brasil, tendo permanecido ativo até a expulsão dos jesuítas em 1759.

31 Nascido em Alenquer, Portugal, por volta de 1538, ingressou na Companhia de Jesus em 1562. Pouco se conhece de sua juventude, mas foi mestre de obras da Igreja de São Roque em Lisboa, na qual continuava trabalhando em 1573. Em 1577 embarcou para o Brasil a pedido dos jesuítas, atuando como arquiteto e revisor em várias localidades do país. Além de Salvador, sabe-se que trabalhou nos projetos de seminários e das igrejas de 0linda, Santos e Rio, onde viria a falecer em 1633 (Alves, 1976; Frade, 2007; Leite, 1938a, 1953, 1965).

32 Desde 0 século XV, as missas celebradas nos navios portugueses não contavam com pão ou vinho consagrados, lacuna criada tanto pelas precárias condições de vida a bordo quanto pelo imprevisível balanço do navio. Essa "missa seca" seria formalmente aceita após 0 Concílio de Trento (1545-1563).

33 Nasceu em março de 1564 em Monteforte in Cilento, tendo entrado no noviciado a 19 de março de 1583. Em 1593, tornou-se adjunto do reitor e companheiro do mestre dos noviços no colégio de Nápoles. Desejando consagrar-se às missões, partiu para Lisboa, tendo sido destinado a trabalhar no Japão junto com 19 outros jesuítas, distribuídos por duas naus. Conforme estabelece o texto, morreu em Salvador, Bahia, a 27 de julho de 1596. Para maiores detalhes, vide Correia et al. (1955).

34 Referência à passagem em que um serafim enviado por Deus purifica Isaías ao retirar um carvão em brasa do altar e o colocá-lo em seus lábios (Isaías 6: 5-7). tinuou com muito gosto, fervor e devoção, assim na doutrina dos meninos como nas pregações aos homens que aos domingos e dias santos se faziam, a quem seu muito espírito deixava entender-se de todos com dobrado gosto e amor. Porém, como os vagares e perplexidades com que andamos em dois climas tão ruins (saindo de um em que estávamos que começou, já naquele tempo, a ser tão frio e tornando atrás ao outro, que é sempre tão quente), junto com a melancolia universal que em cada um tinha muitas causas gerais e particulares, adoeceu toda a gente sem escaparem mais que cinco de quatrocentas e sessenta pessoas que iam na nau - e entre eles o piloto (para ficarmos de todo sem governo: o material por falta de leme a quem obedece a nau e o racional por falta de piloto a quem obedece o leme e manda a via), sem ficar outro que em seu lugar o pudesse fazer com tanta ciência. Adoeceram também todos [os] oito [de] nós que íamos da Companhia [de Jesus], todos juntos e tão gravemente que caso tomássemos alguns dias mais tarde o porto, não sei quantos chegaríamos ao colégio que naquela cidade temos. Do qual vieram nossos padres e irmãos nos desembarcar em barcos e levar para casa em redes (que são as cadeiras, andas ${ }^{35}$ e coches que lá se usam), onde daí a onze dias foi Nosso Senhor servido levar para si dois dos oito e ambos no mesmo dia vinte e sete de julho, o padre Jacome de Vicariis e o irmão João Sanches ${ }^{36}$. Os mais quis guardar para ver mais mares, mais terras e mais trabalhos.

O que desta terra, que foi a primeira estação das sete que corremos nesta romaria, pudera dizer, terá V.R. lido em muitas [cartas] que nossos padres e irmãos de lá escrevem - e ouvido aos que de lá vem. Assim não sei eu que outra novidade maior conte dela que a muita caridade (e mais que fraternal amor) com que do padre reitor Inácio de Tolosa ${ }^{37}$, a quem, por ser vivo, deixo de

35 Par de varais sobre 0 qual se transporta, aos ombros de quatro pessoas, qualquer objeto volumoso ou pesado. Na versão reduzida do Archivum Romanum Societatis Jesu (vide adiante), os doentes teriam sido desembarcados nos braços de seus confrades e levados em redes, 0 que talvez faça mais sentido.

36 Sabe-se apenas que era um irmão coadjutor de origem espanhola. Correia et al. (1955) chamam-no de Bartolomeu Sanchez.

37 "Ignacio de Zolosa" no original. Espanhol de Medinaceli, diocese de Siguenza, ingressou na Companhia em 1560 e veio para o Brasil em 1572 já ordenado, com cerca de 39 anos 


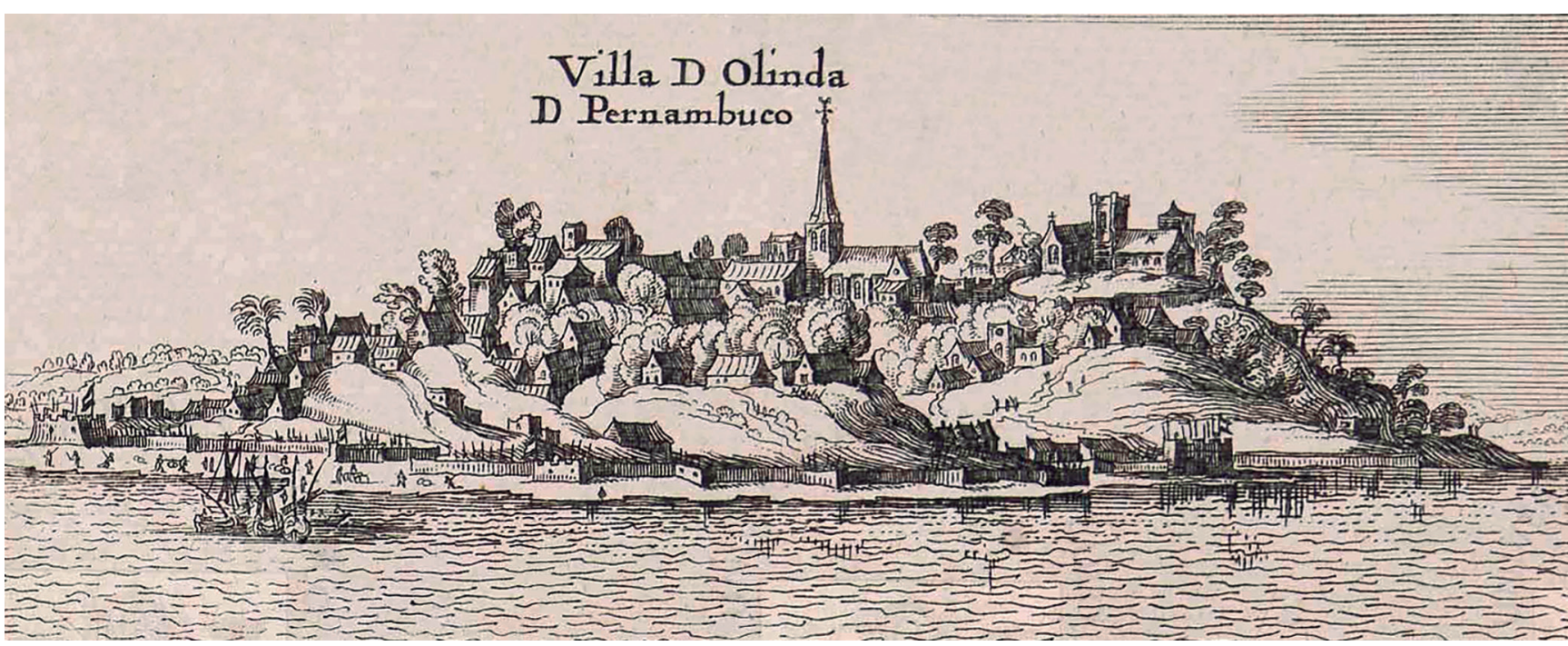

Figura 3. 0 colégio jesuíta de Olinda (acima à direita). Detalhe de “A cidade de Olinda em Pernambuco", gravura de Claes Janszoon Visscher (1630).

chamar santo (bênção própria dos Inácios em nossa Companhia, lançada pelo primeiro, ou herdada ${ }^{38}$ ) e dos mais padres e irmãos daquele colégio, [onde] fomos recebidos, agasalhados, curados e regalados por todo o tempo que ali estivemos, que foram cinco meses menos quatro dias. Porém isto não se pode contar nem escrever por novidade, senão por antiguidade nascida com a Companhia, ainda que por aquelas partes mui crescida e empinada.

O colégio é mui formoso e grande - assim no número dos padres e irmãos, como no edifício - com linda e mui curiosa vista sobre o porto, onde por quatro meses do ano (que são os do verão ou estio, em que nós chegamos $\left.^{39}\right)$, se puderam alugar nossas janelas para a contínua e alegre vista de muitas baleias, que por particulares respeitos seus se vem recolher este tempo no recôncavo daquela baía - e o gastam em contínuas festas, saltos e danças, que não fora pouco impedimento do estudo se não fora tão contínuo. Do que nós nos logramos bem enquanto a convalescença das doenças passadas não deixava olhar para outros livros. Parece que elas o fazem com tanto ar e graça para que não se perca volta sua que não seja vista, tanto que de lá do fundo chegam à superfície da água [e] lançam para cima um gracioso e grande borrifo como de uma pipa de água. Captada assim a atenção aos olhos se vai levantando e empinando mui direita para o céu, até que a natureza (impedindo-lhe de ir por diante e tomar mais do elemento alheio) dá com aquela grã torre de carne - ou peixe - de avesso e a estende sobre a água com uma sonora pancada.

de idade. Doutor em teologia, devia substituir Luis da Grã como quinto provincial, cargo que ocupou desde sua chegada até a segunda metade de 1577. Tornou-se em seguida 0 mestre dos noviços no colégio da Bahia, mas acabou por assumir a direção do colégio do Rio de Janeiro entre 1583 e 1591. No ano seguinte voltaria para Salvador, tornando-se $017^{\circ}$ reitor do colégio da Bahia (1592-1598). Prosseguia ativo em 1600, atuando como pregador, prefeito espiritual e consultor do provincial e do reitor do colégio da Bahia (Kist, 2008; Leite, 1938a; Viotti, 1989)

38 Referência a Inácio de Loyola, fundador da Companhia de Jesus, canonizado pelo Papa Gregório XV em 12 de março de 1622.

390 autor tinha como referência as estações do hemisfério norte, onde o mês de julho corresponde ao verão boreal. No caso do Brasil, os eventos descritos teriam ocorrido em pleno inverno austral.
Muito mais alegre vista - e mais nova - nos deu a nós e à boa parte do colégio um dia uma nuvem descida sobre a água, de tal feição e postura de boca, pescoço e corpo, e com tal fervura ou sorvos de água para cima que pus eu mui pouca culpa à ignorância daqueles que dizem que vêm elas beber ao mar. E depois desta - daí a alguns dias, navegando já para este Reino - vimos no meio do oceano, bem perto de nossa nau, outras quatro ou cinco juntas da mesma figura e feição e na mesma postura e ocupação de matar sua sede $\mathrm{e}^{40}$.

Temos perto da cidade uma quinta, que em algumas cousas particulares - como são a verdura do arvoredo todo o ano (porque o inverno de lá não é de tão má condição, como o nosso, nem tão desumano que dispa as árvores de seus vestidos), na água de muitas fontes e em um lago mais que tanque, entre dois montes, cheio de peixe e marisco, na fruta de espinho ${ }^{41}$ de toda a sorte e em outras naturais da terra, especialmente nos nunca assaz louvados ananases ${ }^{42}$ - faz muita vantagem a muitas que cá se têm por boas e dignas de ver. Nem é de maravilhar de tanta frescura e viço da terra, onde só em cem léguas que há do colégio de Pernambuco [Figura 3] ${ }^{43}$ ao da Bahia, [pois] me disse o padre provincial, que então chegava de lá, que passara quarenta rios tão caudalosos, que nem em jangadas (que são certos paus unidos entre si) se podiam passar vinte deles senão de maré vazia, quando sem a ajuda do mar não ficam tão soberbos. Posto que as verdadeiras causas desta frescura em toda a tórrida zona são mais superiores e por isso tão mal conhecidas dos antigos ${ }^{44}$, que por verem ao sol todo o ano dentro nela ferindo-a sempre com raios direitos - ora

40 Provavelmente uma tromba d'água.

41 Tal expressão costuma designar as frutas cítricas como a laranja a cidra e o limão (vide Leão, 1610).

42 Óbvia alusão ao abacaxi, Ananas comosus (L.) (Bromeliaceae), descrito pelos cronistas que visitaram o Brasil já na primeira metade do seculo XVI.

43 Construída por Gonçalo Coelho em 1551, a Igreja de Nossa Senhora da Graça está situada no chamado morro do Seminário em Olinda. 0 templo e as terras vizinhas seriam doados aos jesuítas para 0 estabelecimento de um colégio, fundado em 1568. Após terem sido destruídas pelos holandeses em 1630, ambas instalações seriam reformadas no ano de 1661.

44 Muito presente em fontes do século XVI, semelhante designação deve ser entendida como uma referência aos autores clássicos. 
de um trópico, ora de outro - Ihes pareceu que estaria sempre ardendo não em sol, senão em fogo. E como tal a tinham por desabitada ainda os grandes cosmógrafos, cuja opinião seguiram ambos os poetas Virgílio e Ovídio, dando a cada uma de todas as cinco zonas, em que a terra também está repartida, suas propriedades ${ }^{45}$.

Ali vimos o animal preguiça, de cuja preguiça será pouco tudo o que por cá se terá ouvido. De que a terra é tão provida que não foi necessário mais que eu mostrar em uma aldeia nosso desejo de ver um destes animais, para me trazerem logo os índios dois do mato. Porque como eles gostam muito das folhas de certa árvore a estas os vão buscar ${ }^{46}$, porque se ele subiu acima alguma hora nesta vida, ai há de estar ainda. Coisa é vagarosíssima e molestíssima ver o tempo que há mister para andar quatro passos - e assim não tem necessidade de prisão, porque sua própria preguiça o é bastantíssima, pois nem para fugir de ameaças da morte dá um passo mais apressado e ainda que tem muito bons pés e mãos (e mui disformes unhas de comprimento de um dedo), sempre leva o corpo [de] arrastos estendido pelo chão, porque os pés e mãos não se cansem nada em o trazer às costas e sustentar, com não ser maior que o de uma raposa, antes menos alguma coisa.

Vimos outro animal a quem os brasileiros chamam tatus ${ }^{47}$, ao qual a natureza armou de caçolete, espaldar, coxetes, manoplas e todas as mais peças com que a arte depois aprendeu a armar um homem de ponto em branco ${ }^{48}$. E se Deus e a natureza não fazem coisa debalde, como Aristóteles $\mathrm{diz}^{49}$, bem pudera entrar entre seus problemas este: porque a natureza armaria a este animal com tais armas? Ou porque Ihe estimaria, ou guardaria tanto a vida, para lha assegurar tanto nas garras?

Vimos mais uns passarinhos que depois de se enfadarem de ser borboletas e de viver em tão baixo e tão imperfeito estado, com desejo de subir e valer (que até nos brutos parece que reina), se passam a outro mais alto e mais perfeito, fazendo-se passarinhos muito lindos e de cores mui louçãs de que há muitos na nossa quinta, que no modo de voar e tomar pouso não podem, todavia, encobrir quem foram em outro tempo. Cuja metamorfose, ou transformação, crerá facilmente quem crer na do cão do Japão (que enfadado também de ser cão na terra, se

45 No primeiro livro de "Metamorfoses", Ovídio declara "Quarum quae media est, non est habitabilis aestu" ("Das quais a que está no meio não é habitável pelo calor"), enquanto Virgílio, no primeiro livro das "Geórgicas", menciona "Id circo certis dimensum partibus orbem per duodena regit mundi sol aureus astra. Quinque tenent caelum zonae: quarum una corusco semper sole rubens et torrida semper ab igni [...] has inter mediamque duae mortalibus aegris munere concessae diuom" "“Cinco são as celestes zonas, das quais uma está sempre abrasada pelo sol coruscante e fogo tórrido [... Entre estas e a do meio existem duas outras concedidas pelos deuses aos mortais"). Baseadas na "teoria das cinco zonas" concebida por Parmênides de Eléia e veiculada por Aristóteles, ambas passagens fazem clara alusão à pretensa impossibilidade de seres humanos subsistirem na chamada "zona tórrida" (Ovídio, 1916; Virgílio, 1999). Décadas mais tarde, outros jesuítas como Simão de Vasconcellos (1663) continuariam a citar esses autores clássicos dentro do mesmo contexto. Para maiores detalhes, vide Papavero \& Teixeira (2003); Papavero, Teixeira, Llorente-Bousquets et al. (2004) e Randles (1980).

46 Provável referência às embaúbas (Cecropia spp.), cujas folhas servem de alimento para as preguiças.

47 "Brazis" e"Zatûs" no original (vide Anexo 1).

48 Equivalente a "com esmero" ou "com apuro".

49 "A natureza nada faz em vão", conforme assevera Aristóteles na "De Anima", livro III, parte 9 (Aristóteles, 1907). vai também a seu parecer melhorar e fazer[-se] peixe no mar, que eu vi e tive nas mãos em Lisboa, com metade da conversão já feita, que os nossos padres de lá [do Japão] mandaram no ano de 1576) [mudança esta] pouco mais ou menos. $\mathrm{O}$ que parece ser mais, porque aqueles [passarinhos] não mudam mais que a natureza e esse [cão muda] a natureza e elemento ${ }^{50}$.

Crerá isto facilmente São Basílio e ajuntara estes dois exemplos, se os soubera, ao seu, com que ele prova a ressurreição na homilia oitava de seu Hexaémeron, por estas palavras: Que dizeis vós, pergunto (diz o Santo) os que não credes a São Paulo sobre a mudança, que diz há de haver na ressurreição? Se vós vedes tantas aves do ar mudarem também suas formas, como se conta também daquele bicho da Índia que tem dois cornos e este se converte primeiro em lagarta e depois, andando o tempo, se faz bicho de seda e nem ainda persevera nesta forma, mas indo-se aquelas moles pelinhas de seus cominhos pouco e pouco alargando à feição de asas, se faz desta maneira finalmente ave ${ }^{51}$.

50 Gaspar Afonso fornece uma versão simplificada de uma observação assaz peculiar registrada pelo irmão Luis de Almeida em uma carta escrita na ilha de Shiki no dia 20 de outubro de 1566: "[...] Naõ deixarei de vos contar hũ monstro que vi no Reino de Gotó [Gotô] este inuerno que la estiue, pera que tenhais mais materia de louuar a Deos em suas obras. Ha naquelle Reino hũ mato, que sera de seis leguas, no qual ha muita caça, e antre ella hũs animais como cães, mas os pes, \& as mãos mais curtos. Tem um pello louro \& macio como seda: os quaes os lapões tem por grandissima igoaria, e porque a pelle antre elles val muito, quãdo se come em algũ bãquete chamuscamno, \& gisamno com aquella pelle por mais estado, \& custo. Estes animaes depois de muito velhos vão buscar o mar, \& lançãose nelle, \& conuerten se pouco \& pouco em hũs peixes grãdes como atuns, \& tomãnos, \& ja conhecem que primeiro foraõ animaes da terra, cousa q̃ eu tinha por fabula, que podesse ser hum animal da terra sem se corromper, \& poderse mudar em outro animal, \& por me dizerem \& affirmarem que tomauão algũs q̃ erã̃ ja meos mudados em peixe, \& meos eraõ ainda animaes, desejei ver isto, \& acertou trazerem hum a elRei meo peixe, \& meo animal, 0 qual elRei me mandou, de que eu fiquei cõfuso, \& naõ podia ser animal da terra, nem podia negar irse conuertedo todo em peixe, \& porque he cousa tanto fora da natureza Ihe mandei cortar os pès \& as mãos, e tirarlhe os olhos, \& secos lhos mando, pera que vejã̃ 0 que nunca se achou ategora em escritura. A maõ vai ja conuertida em espadana, mas ainda com as pontas das vnhas, \& com o cabelo, e o pè que he meo espadana do cabo, leua ainda os dedos cõ as jũturas, e vnhas, mas vai por baixo crecendo a espadana. Mas isto pera 0 ver inteiro he muito differente" (L. de Almeida, 1598). Uma variante seria reproduzida pelo padre Sebastião Gonçalves e aparece no capítulo sexto do décimo livro de sua "História dos religiosos da Companhia de Jesus nos reinos e províncias da Índia Oriental": "No Gotto aconteceo aquella nova metamorfose ou transmutação d'hum animal terrestre em peixe do mar. Há certo animal como cam com os pees e mãos curtas; tem o pello louro e macio como seda, o qual os japões tem por grande iguaria. E porque a pelle vai muito, quando se come em algum banquete chamuscão-no e o guisão com a pelle por mais estado e custo. Este animal depois de velho se lança no mar e pouco a pouco se vay convertendo em peixe tamanho como atum. Hum destes foy tomado e levado a el-rey [do Gotto], o qual elle mandou de presente ao Irmão [Luis de Almeida]. Não estava ainda de todo convertido em peixe; a mão estava já convertida em espadana, mas ainda com as pontas das unhas e com 0 cabello, e o pee era meya espadana; tinha ainda as junturas e unhas. Mas vê-lo inteiro hé muito differente que vê-lo escalado, ainda que faz mais espanto e credito vê-lo meyo aquatil e meyo terrestre" (Gonçalves, 1962). Malgrado a natureza desse misterioso "cão do japão" permaneça indefinida, vale lembrar que uma nota do padre José Wicki (in Gonçalves, op. cit.) associa esse relato ao comentário do Conde de Ficalho (in Orta, 1891-1895) sobre o dugongo, Dugong dugon (Müller, 1776) (Sirenia), um mamífero aquático sem qualquer semelhança com a presente descrição.

51 Referência um tanto confusa ao comentário que São Basílio (329-379), arcebispo de Cesareia, faria em seu célebre "Hexameron" (i.e., "Os seis dias da Criação"), escrito sob a forma de nove homilias. A passagem em foco pertence à penúltima delas e associa a metamorfose do bicho-da-seda à ressurreição de Cristo, a saber: " 0 que você tem a dizer aos que não acreditam na afirmativa do apóstolo Paulo sobre a mudança da ressurreição, quando se vê muitos dos habitantes do ar mudando suas formas? Considere, por exemplo, o relato sobre o cornudo verme da Índia, o qual primeiro se transforma em uma lagarta e depois com o tempo se converte em um casulo, mas não continua nessa mesma forma, mas acaba por possuir largas e delicadas asas". São Baślio parece ter sido o primeiro autor do 0 cidente a mencionar claramente a metamorfose do bicho-da-seda de crisálida à mariposa. Para maiores detalhes, vide Gilroy (1845), Glacken (1967), Guerra (2013) e Pariset (1862-1865). 


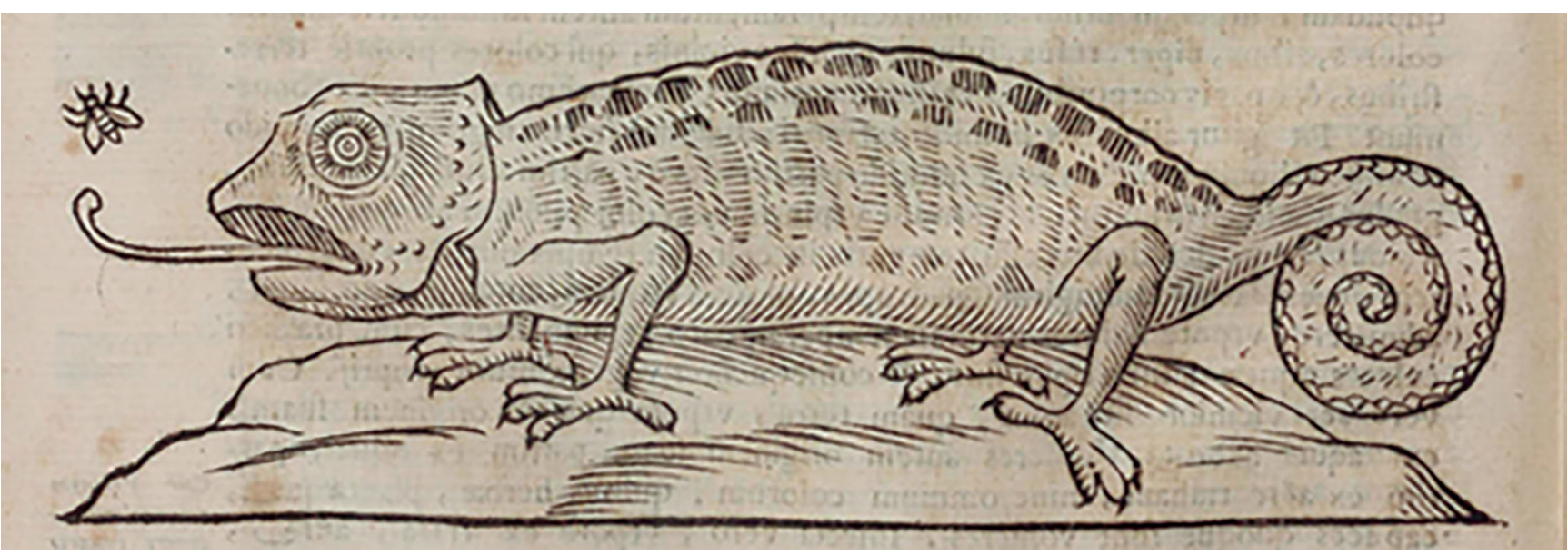

Figura 4. 0 camaleão, Chamaeleo chamaeleon, segundo gravura da "Ars Magna Lucis et Umbrae" de Athanasius Kircher (1646).

Crera-o também São Gregório, o qual - na oração quinta de teologia, falando da variedade de nascimentos e gerações com que a natureza produz os animais - diz o seguinte: 'Dizem que se geram não só as mesmas coisas das mesmas e diversas de diversas, mas também as mesmas de diversas e diversas das mesmas ${ }^{\prime 52}$. E ajunta logo como maior maravilha da natureza, que há animais em que a natureza se quer mostrar tão magnífica e poderosa que, deixando de ser os que são de uma espécie de animais, se passam e convertem em outra.

Das letras e habilidades dos bugios ${ }^{53}$ se sabe cá muito pouco e muito menos de seus sermões e exortações. Folgara eu muito de entender o seu latim, porque não houvera de me escapar pregação para saber sobre que matéria tratava o pregador, que virtudes persuadia a seus ouvintes e a delicadeza de seus conceitos. Só se sabe ser a pessoa do pregador mais reverendo e ser acompanhado ao púlpito, por maior honra e autoridade, de dois acólitos que servem, durante o sermão, de lhe estarem alimpando a baba que - com o muito zelo, fervor e corrente de palavras - Ihe cai da boca, sem faltar mais que vestir-Ihe no cabo uma camisa quente por não lhe dar algum ar. Afora outras mil coisas suas desta qualidade, que podem bem inquietar o siso de seus ouvintes. Entre eles vimos alguns de cheiro, louros e mui formosos, que em Ihe mudando os ares morrem logo - e por isso chegam cá poucos. Lembra-me que dizia o irmão Fulgêncio Freire - quando por este Reino veio do Cairo, [para] onde fora levado cativo [no momento em que estava] tornando para a Índia ${ }^{54}$ - que vira no mar Roxo alguns tamanhos como mulas - e nós vimos outros aqui no Brasil tamaninos como ratos.

Deixo as cobras de quarenta palmos de comprido, a que os Índios chamam jibóias, que se não foram tão dobradiças podiam servir de mastaréus nas naus, ou de

520 trecho em questão de fato pertence a Gregório de Nazianzo (329-389), patriarca de Constantinopla, teólogo e escritor cristão. Está no quinto dos seus 44 discursos que integram as chamadas "Orationes" e pode ser assim traduzido: "Pois não apenas iguais geram iguais e diferentes engendram diferentes, mas também iguais são concebidos por diferentes e diferentes por iguais. Há também criaturas que se afastam de alguma forma de sua verdadeira natureza e sofrem mudanças e transformações de uma criatura em outra graças à magnificência da natureza". Para maiores detalhes, vide Daley (2006).

53 "Bogios" no original (vide Anexo 1).

54 Vide nota 139 traves nas casas. Tragam estas um veado inteiro sem se Ihe atravessar na garganta nem um ossinho de toda sua armação - e assim eu as vi por lá pintadas com eles na boca. E por se manterem de tão boa carne - e de outras semelhantes que pelo mato acham - se fazem tão saborosas ao gosto dos índios que quando eles as podem matar, as têm por singular iguaria. E por tal também tem a carne dos lagartos, que lá são monstruosos, a que eles chamam jacarés e nós podíamos chamar crocodilos $^{55}$. E o melhor é que os portugueses, ainda que nascidos cá em Portugal com o asco que todos temos a cobras e a lagartos, mudado o clima mudam também a natureza e perdem todo este assombramento - e acham em sua carne tanto gosto como os índios, de maneira que eu me espantei de ver [o] quanto um se saboreava na posta de um [jacaré] que se matou em um ribeiro onde eu estive uma tarde.

Os camaleões, que têm alguma figura de lagartos, são também muito maiores que os que eu tenho visto em África e em Mazagão ${ }^{56}$, onde estive, mas nem por serem maiores no corpo e terem maiores estômagos, metem neles mais alimento uns que os outros, contentando-se todos com o ar e algumas moscas que todavia pescam com a língua sutilissimamente, do que eu posso ser testemunha de vista - e quem pesca moscas também pescará outra coisa, se achar que diga com seu estômago [Figura 4$]^{57}$. E quando não, não anda tão puro e limpo o elemento do ar - e da água - que não possa um com isso que traz misturado e envolto consigo, sustentar os camaleões na terra e outros muitos peixes no mar por todo o

55 "Crocodilhos" no original (vide Anexo 1).

56 Fortaleza construída em 1514 por Dom Jaime, Duque de Bragança, em consequiência da conquista de Azamor, cidade situada na costa atlântica de Marrocos.

57 A crença do camaleão vivia apenas de ar remonta à Antiguidade, tendo sido mencionada no Livro XV, das "Metamorfoses" de Ovídio ("id quoque, quod ventis animal nutritur et aura, protinus adsimulat, tetigit quoscumque colores", i.e.: "e há também um animal que se alimenta de ar e que toma a cor de tudo que toca", vide Ovídio, 1916) e no Livro VIII, capítulo 51 da "História Natural" de Plínio ("ipse celsus hianti semper ore solus animalium nec cibo nec potu alitur nec alio quam aeris alimento", i.e.: "sempre erguido com a boca aberta, é 0 único animal que não se nutre de comida, bebida ou outro alimento além do ar", vide Plínio, 1979-1984). Athanasius Kircher (1646) teria sido o primeiro a contestar parcialmente 0 mito ao afirmar que esse réptil também comia moscas, comentário acompanhado de uma sugestiva gravura (vide Figura 4). Para alguns cronistas coloniais (e.g., Thevet, 1557) a preguiça, Bradypus variegatus Schinz, 1825, seria comparável ao camaleão por também viver de ar. 
tempo que Ihe faltar outro alimento de mais sustância. O que não poderiam fazer se estivessem naquela pureza com que Deus os criou no princípio do mundo e que lhe tornará a dar [no] fim ${ }^{58}$.

Os índios conservam ainda algumas propriedades do estado da inocência, como terem por escusado o vestido ainda dentro nas nossas cidades, [algo] que os portugueses não estranham por lhes ser coisa tão natural e contínua. Vivem muitos casais em umas grandes casas - como um largo e comprido dormitório - e destas casas tem cada povoado mais de dez ou doze, conforme a gente que neles habita, sem chaves, nem arcas, nem memória de fechar ninguém suas coisas para que outro não lhas furte, livre de todos os sobressaltos e temores de acharem nada menos.

O recebimento dos hóspedes - e primeira mostra de prazer logo em chegando, como a mim receberam em uma destas aldeias - é um pranto desfeito das mulheres chorando, contando todos os trabalhos e perigos que poderíamos ter passado ${ }^{59}$. Acabado este ofício (em que elas não dão vantagem às preficas romanas) e enxutas as lágrimas (com a brevidade com que diz que elas enxugam e secam, quando se não derramam mais que por cumprimento e cerimônia ${ }^{60}$ ), se segue todo o mais verdadeiro agasalho e festa que nós cá fazemos aos hóspedes amigos.

Coisa é muito para ver um alarde seu e mostra de sua guerra, de que deu uma alegre vista defronte de nosso colégio a gente de três aldeias, que por ocasião de inimigos franceses vieram guardar um passo junto à cidade. Porque com tudo fazem pavor e espanto ao inimigo, com as pinturas do corpo, com as plumas de várias cores (e finíssimas), com a grita e os assaltos em que são ligeiríssimos e contínuos ${ }^{61}$ enquanto dura a batalha, sem darem lugar para se fazer neles pontaria nenhuma. Na grandeza dos arcos, maiores que os de todas as outras nações, que deles usam na fúria e força das setas, tamanha que - ainda que o corpo delas seja daquelas espigas que as canas lançam depois de velhas e o bico [seja] de pau inserido nelas - nós vimos uma que o capitão da nossa nau comprou a um índio para trazer e mostrar por maravilha em Portugal, por lhe ver passar com ela juntamente de um tiro duas tábuas de uma porta de não sei quantos dedos de grosso.

Exortam-se a estas guerras - e outras coisas a que de comum hão de acudir todos os do povo - com pregações que fazem de noite, andando o pregador pelas ruas rodeando as casas e pregando. $E$ faz este ofício aquele que melhor linguagem - e corrente - tem. Ouvi eu algumas pregações destas, estando entre eles, com tal fervor e eficácia para persuadir, que sem as entender ia-me também rendendo e persuadindo aos acompanhar.

58 Nessa passagem, a crença milenarista da decadência e corrupção do mundo constitui uma engenhosa justificativa para sustentar a ideia de que determinados animais poderiam sustentar-se apenas do ar ou da água.

59 Interessante referência à chamada "saudação chorosa" observada anteriormente por cronistas como Léry (1578).

60 Malgrado as "Tusculanae Disputationes" de Cícero (1927) discorram sobre as preficas - carpideiras profissionais da antiga Roma que celebravam as virtudes do defunto e pranteavam sua morte com choros e lamentos - Gaspar Afonso na verdade pretendia referir-se a "De Inventione", conforme fica claro na versão mais resumida de sua carta (vide nota 110).

61 A versão reduzida do Archivum Romanum Societatis Jesu (vide adiante) fala de "saltos em que são ligeiríssimos", o que parece ser bem mais adequado.
Na guerra e na caça são tão destros em seus tiros que sem pontaria com o olho que nós fazemos (antes rindo-se muito disso quando eu lhe dizia que a fizessem) não erram um passarinho, como eu vi a um - por me fazer festa - derrubar muitos, um após outro, com tanta certeza que pude eu dizer com mais verdade neste sentido por ele, o que Ovídio disse n'outro por Télemo: Quem nulla fefellerat ales ${ }^{62}$. Entre os quais matou a um que tinha a língua como dois dedos maior que o bico, que se fora conhecido dos antigos não escapara a Pierio de o pôr entre os seus hieróglifos, ou por figura dos que falavam demasiado, ou dos que têm mais palavras que obras ${ }^{63}$.

E se é muito para ver a ligeireza de seus saltos na guerra, nada menos o é - na paz - o sossego de seu corpo na representação de uma festa ou folia, na qual vão um após outro em uma comprida fileira singela - e não dobrada - com tão miúdos passos que não chega cada um a mais que a medida de um pé inteiro, fazendo certo som com a boca e alguns outros instrumentos, sem faltar a pancada a que todos à uma acodem com pé e boca - e [o] som de todas as mais coisas que tangem. Com o corpo sempre inclinado um pouco para diante e o rosto no chão com tanta prontidão e ponderação, como se fosse cada um dos da dança cuidando no governo do mundo, coroados de formosas penas em lugar de capelas ${ }^{64}$ e outras coisinhas deste teor, que nas cores não dão nenhuma vantagem às que nós fazemos de flores e boninas.

Em uma destas aldeias recebi estranha consolação vendo as horas de Ave Marias ordenar os meninos à porta de nossa igreja - conforme a ordem que de nossos padres têm para o fazer assim - e a cada dia [fazer] uma procissão até à cruz, que está um pedaço fora da povoação, cantando a doutrina: entoando dois e respondendo os outros (de que eu não entendia mais que Jesus e Maria) com tanta devoção e ordem que não é necessário na procissão quem governe.

E se muita é a compostura dos meninos na procissão, nada menos é a dos pais e mães na igreja, à qual todavia trabalham de vir mais cobertos e estar atentíssimos à missa e pregação, que em sua língua Ihes vi fazer algumas vezes os nossos padres. Os quais a tem por mui doce e tão copiosa que algumas coisas nomeiam os homens por uma palavra e as mulheres por outra, respeitando - parece - a suavidade e delicadeza da pronunciação a que os homens não chegam.

Antes de contar um caso dos tempos que ali estivemos, contarei outro que tinha sucedido antes algum tempo, que para mim foi também novo e maravilhoso quando o ouvi e vi pintado - e assim o será para outros. O qual sucedeu ao padre Morinello65, italiano, e ao pa-

62 "Zelemo" no original. Essa referência em latim pertence ao Livro XIII das "Metamorfoses" de Ovídio: "Telemus Eurymides, quem nulla fefellerat ales", ou seja, "Telemus filho de Eurymides, ao qual nenhum pássaro tinha enganado" (0vídio, 1916).

63 Pierio Valeriano Bolzani (1477-1558), humanista italiano da Renascença autor da "Hieroglyphica", o primeiro dicionário de símbolos da época publicado em Basiléia em meados do século XVI (Bolzani, 1556).

64 Grinaldas de flores ou plantas aromáticas.

65 Giuseppe de Morinello teria chegada ao Brasil a 29 de março de 1575 chefiando a 16a leva de jesuítas e aqui permaneceu por pouco tempo, voltando para a Itália antes de 1584 (Kist, 2008; Leite 1938a; Viotti, 1989). 
dre Manoel Viegas ${ }^{66}$, português, na praia de Piratininga, tal que só sua medonha pintura, que nos mostraram e deram, faz horror e pavor a quem a olha. Indo pois ambos os padres e dois meninos índios por uma praia lhes apareceu diante um fantasma ou figura de homem, negra com as costas e entranhas ardendo em fogo, com um passo vagaroso como quem os ia aguardando. Até que enfim chegaram e cuido que Ihe falaram. Depois se foi aquela figura andando para o mar, de onde saíram alguns negrinhos e indiozinhos a o receber - e ferrando nele o foram metendo pela água até desaparecer, custou a visão bem a ambos os padres. Para a interpretação que alguns me deram das figuras deste enigma, suponha V.R. a injustiça com que alguns portugueses, naquela província, fazem entradas pelo sertão a cativar índios e trazê-los para servirem em suas casas e fazendas que tem cá ao longo do mar: causa da antiga contenda e encontros que sobre isso eles têm com nossos padres por lho impedirem, acudindo pela liberdade dos índios com a lei divina e natural e provisões reais, que para isso lhes têm alcançado.

Dizem pois alguns intérpretes do enigma e suas figuras, ser este que ia ardendo uma afamada cabeça destas entradas que havia pouco que por ali junto era falecida. E que quis Nosso Senhor mostrar que os índios, que ele ia buscar e trazer do sertão para o mar, o vieram também buscar a ele e levaram para aquele mar e lago infernal. $E$ por ser cabeça no crime, levava também maiores labaredas nela. De maneira que eu não pude, com o fogo, divisar na pintura se ia descabeçado. $\mathrm{E}$ com tudo isto não quer a avareza desistir desta empresa, antes - estando nós lá - andava atualmente no sertão uma grande companhia de soldados para o mesmo efeito - e o pior é que se faz o negócio com a autoridade pública, entrando nisso os do governo, paliando ${ }^{67}$ tudo com razão de Estado, dizendo que de outra maneira se perderá o Brasil por falta de escravaria necessária para os engenhos de açúcar, sendo a verdade o particular interesse de proverem seus engenhos e fazendas de índios que não lhes custam nada e não de negros de Guiné que Ihes custam muito. Ainda que mais caro custou a toda esta soldadesca então a empresa em que andava, porque de enfermidades morreram lá muitos e os que escaparam se tornaram com o gasto feito e sem proveito, porque nem um só índio trouxeram, nem ainda acharam. O que tudo o padre reitor Inácio de Tolossa Ihes tinha no púlpito prognosticado, ou profetizado, antes de se partirem, trabalhando de os apartar e tirar de tão injusta guerra. E foi permissão divina e cuidado paternal que ele tem dos seus, porque acabando eles de chegar, chegaram nas suas costas os principais de vinte e cinco mil almas, que lhes não ficaram mui longe, a buscar padres nossos para os irem trazer e meter no rebanho daquele grande e bom pastor - e

66 Nasceu em Portugal em 1533 em Marvão, distrito de Portoalegre. Tendo perdido seus pais, veio para 0 Brasil no grupo de outras crianças órfãs que os jesuítas haviam pedido para que se tornassem catequistas de jovens indígenas no Brasil. Em 1566, aos 23 anos, entrou para a Companhia, sendo ordenado sacerdote na Bahia em 1562. Cinco anos depois foi para São Paulo, fazendo os primeiros contatos com os Maromoni, que se encontravam no litoral. Compilou um vocabulário maromoni, traduziu nessa língua o catecismo tupi, além de elaborar com Anchieta uma gramática. Morreu em São Paulo aos 75 anos de idade (Prezia, 2009).

67 Mesmo que encobrir ou acobertar. por serem suas as encobriu e livrou dos lobos que com tanta sede as buscavam.

Agora quero contar um milagre do bem-aventurado Santo Antônio, que por ser coisa do nosso tempo - ao menos no castigo de forca que se deu a muitos franceses, estando nós ali, por terem dado ocasião ao milagre. Pouco antes de partirmos de Lisboa o ano atrás de [1]595, tinham alguns navios franceses saqueado o nosso Castelo de Arguim ${ }^{68}$ - que está junto ao cabo Branco contra a costa da Guiné - e pouco contentes com as afrontas que fizeram aos santos em suas imagens na terra, embarcaram consigo em uma das naus um Santo Antônio de vulto de boa estatura para se recrearem no mar, metendo-lhe por seu desenfadamento, como hereges que eram ${ }^{69}$, um broquel no braço dizendo que se defendesse - e assim jogando com o santo as cutiladas, o encheram de muitas feridas. Coisa maravilhosa que com o santo aprender e usar tão pouco esta arte em sua vida e mocidade pelas ruas de Lisboa, onde com tanta quietação se criou, aqui se mostrou tão destro em seu exercício que ainda que não era mais que um só contra tantos, se muitas recebia no corpo cá em cima no convés da nau em cuja praça se fazia a festa, muito mais cruéis Ihas dava lá por baixo no paiol, no biscoito, na carne, na água e pelos arcos das pipas, fazendo-lhe apodrecer um e desamarrar outro sem se eles precatarem. Até que cansados e enfadados das festas o lançaram ao mar, fazendo sua derrota para o Brasil para continuarem por aquela costa com sua pilhagem. Se não quando daí a poucos dias se acharam sem mantimentos nem água, de maneira que uma das naus, forçada da extrema necessidade, se foi entregar voluntariamente ao governador da Bahia, que por se entregarem por sua vontade ficaram depois com as vidas até nossa partida. Outros, querendo se prover pela costa à força de armas, desembarcaram em duas partes diversas e em ambas foram tomados e depois enforcados na cidade. E porque soubessem eles muito bem que assim se sabia Santo Antônio defender e ofender, ao tempo que vinham trazendo uma destas esquadras presa para a cidade por uma grande e comprida praia, viram ao longe um vulto e indo andando e chegando mais, Ihes ia parecendo homem - e chegando de todo acharam ser o mesmo Santo Antônio com suas feridas que eles tinham acutilado e lançado ao mar, o qual chegando primeiro que eles ao Brasil (com a ligeireza com que ele veio duas vezes de Itália a Lisboa e com tanta facilidade, agora pelo mar como então pelo $\mathrm{ar}^{70}$ ) os estava ali esperando não deitado mas em pé - tão amigo da justiça então em livrar os inocentes, como agora em castigar os culpados - cuja vista assim e naquela postura causou um grande sobressalto e pavor aos franceses. Parece que Ihes quis o santo dizer ali que ele os trazia e que para serem agasalhados como eles mereciam - e em efeito o

68 Situada quase em frente ao cabo Branco, a ilha de Arguim viria a ser o primeiro entreposto comercial dos portugueses na costa africana. A fortaleza teria começado a ser construída em 1455.

69 Clara alusão aos protestantes franceses, também chamados huguenotes.

70 Em ambos casos, Santo Antônio teria viajado milagrosamente da Itália a Lisboa para socorrer seu pai, na primeira ocasião entregando-lhe os documentos necessários para livrá-lo de um processo e na segunda para salvá-lo de ser degolado por uma falsa acusação de assassinato (Lopes, 1868). 
foram - tinha ele vindo por seu aposentador diante e os estava ali aguardando ${ }^{71}$. Está agora esta imagem em uma igreja sua de religiosos da Piedade, curada já das feridas, que nós vimos com muita consolação nossa por vezes, tão venerada como ela merece ${ }^{72}$.

Criam-se por todo o Brasil uns bichinhos - que lá chamam tungas - e nas Índias - aonde também abrange esta praga - niguas ${ }^{73}$. Invisíveis em seu nascimento, [são] tais que se não dá fé deles senão depois que pegados nos dedos dos pés sobre as unhas ${ }^{74}$ - e comendo neles delicadissimamente como ouções ${ }^{75}$ - vêm a crescer e fazer-se às vezes tamanhos como camarinhas ${ }^{76}$ ou grãos de aljôfar, porque tais parecem eles quando os tiram daquelas celas que cada um lavra para si sobre o dedo. Praga, de que ainda os que andam descalços levam a pior, ninguém ainda que muito calçado lhe escapa.

Dá-se por lá tão abundante o arroz, que o que cá tem os homens por mimo, vi eu lá dar por cevada aos cavalos. Deixo o bálsamo ${ }^{77}$ - que na capitania do Espírito Santo se tira de certas árvores - e a particular e maravilhosa virtude que tem para curar feridas, de que eu pudera dar espantosos e milagrosos exemplos que deixo, porque não haja quem pergunte à cirurgia que mal lhe fez coisa tão santa para não usarem dela? E o mesmo dissera de outro óleo, que lá também se tira, que eles chamam de copaíba $^{78}$.

E com isto nos saímos do Brasil e demos à vela para onde Nosso Senhor for servido, dizendo com Enéias:

Diversa exilia, diversas quarere terras, Incerti quo fata ferant, ubi sistere detur, ${ }^{79}$

quando saiu de Tróia em busca de diversos desterros por terras desertas sem saber para onde os fados o levavam nem aonde o deixariam descansar. [Tal] como nós saímos, ainda que contra o parecer de uma celebérrima feiticeira daquela cidade, ficando ela bem sentida de se lhe não

71 Ou seja: como seu hospedeiro, tinha vindo adiante e os estava ali aguardando.

72 Tendo dado à praia de Itapoã, a imagem em questão seria entregue a Francisco Dias d'Ávila, que a colocou na capela de seu solar. Passaria posteriormente para a Igreja da Ajuda e por fim ao Convento de São Francisco (Dorea, 2006). Também conhecido como "o milagre de Santo Antônio de Arguim", esse episódio seria descrito por autores como Agostinho de Santa Maria (1722); Calmon (1939); Jaboatão (1858-1862); Leite (1938b) e Vicente do Salvador (1889).

73 "Zungas" e "nigoas" no original (vide Anexo 2). No caso, 0 autor está se referindo às Índias 0cidentais, pois o nome em questão só é empregado em certos países hispano-americanos.

74 Na verdade, sob as unhas, um claro equívoco que seria repetido em outras partes do texto.

75 Nome utilizado para designar Acarus siro Linnaeus, 1758, praga bem conhecida por infestar tanto cereais armazenados quanto outros alimentos como o queijo.

76 Designação aplicada a Corema album (L.) (Ericaceae), arbusto que produz pequenas drupas brancas comestíveis que de fato lembram as fêmeas ovadas do bicho-do-pé.

77 A julgar pelo teor de todo o parágrafo, uma referência à resina extraída da cabriúva ou pau-de-bálsamo, Myroxylon peruiferum L.f. (Fabaceae), substância muito empregada na farmacopeia da época.

78 Trata-se da seiva do pau-de-óleo ou copaíba, Copaifera langsdorffii Desf. (Leguminosae).

79 Em latim no original. Trecho do terceiro livro da "Eneida", onde Virgilio escreve "Postquam res Asiae Priamique euertere gentem immeritam uisum superis, ceciditque superbum llium et omnis humo fumat Neptunia Troia, diuersa exsilia et desertas quaerere terras auguriis agimur diuom, classemque sub ipsa Antandro et Phrygiae molimur montibus Idae, incerti quo fata ferant, ubi sistere detur, contrahimusque uiros", ou seja: "Depois que o reino da Ásia e a gente injusta de Príamo pareceu bem aos súperos destruir e caiu a soberba Ílion e toda a Tróia Netúnia fumega pela solo, exílios diversos e terras selvagens a procurar fomos levados pelos augúrios dos deuses. A frota construímos sob a própria Antandro, nas montanhas do Ida Frígio; incertos para onde os fados nos conduziam e de onde nos fosse dado parar, reunimos os heróis" (Virgílio, 1999). darem mais crédito aos seus vaticínios do que se dava aos de Cassandra. A qual [feiticeira], na Igreja de Santo Antônio, disse à mulher de um capitão de Mombaça ${ }^{80}$ (que na nossa nau ia) que se não embarcasse mais nela, porque a nau não havia de ir (como em efeito não veio) a Portugal, como a mesma senhora logo - lá bem temerosa - nos disse, perguntando-nos: havíamos nós de deixar de embarcar na nau pelo que a feiticeira dizia? Bem é verdade que eu via já o formal e material da nau de maneira que - sem o espírito de São Paulo, mas com o seu temor - também dizia antes de partirmos, muitas vezes, o que ele dizia antes que a nau em que ele vinha partisse da ilha de Cândia ${ }^{81}:$ 'Vejo com quanta perda e dano não só da carga, mas também da nau e de nossas vidas, há de ser esta navegação!'82 Como na verdade o foi, assim a sua como a nossa, alijando-nos também [de] muita fazenda (com bem de mágoa minha, que via ir os caixões inteiros e cheios ao mar) e morrendo-nos depois muita gente e dando enfim a nau à costa na ilha de São Miguel, onde morreu queimada pelos que nela aí chegaram voluntariamente, por se não aproveitarem dela os inimigos com que ali pelejou, por ser ela uma só e eles terem cento e setenta velas ${ }^{83}$.

Queimada assim esta fênix, porque só ela no mundo (depois que a Índia é nossa) fez tão desvairada viagem, que não podendo em três anos chegar uma vez ao Oriente, aonde levava a proa, chegou duas ao Ocidente. Chegou outra vez a nascer de suas próprias cinzas, porque tirando um piloto daquela ilha isso que ficou por arder debaixo da água, fundou sobre ele um navio para o Brasil, sem fazer este discurso onde havia tanta razão para o fazer. Assim como Deus - por culpas dos homens - lançava maldições às coisas que as não tinham e de que eles se serviam para que lhes não servissem nem aproveitassem, como fez à figueira de Jerusalém ${ }^{84}$, assim por algumas culpas ocultas poderia ter lançado outra maldição a esta nau - tão derrotada e tão acossada de todos os elementos: terra, mar, ar e fogo - para que não servisse nem aproveitasse mais a ninguém, nem se colhesse outro fruto dela mais que perda de todos os que nela o buscassem. Como sucedeu a este piloto, porque tendo-a carregada para a Brasil de toda a fazenda que nela pôde meter, estando ele dormindo em terra a noite antes de dar à vela, levantou-se uma forte tormenta, que caçando as amarras ${ }^{85}$ e arrebatando a nau, não cessou até não dar com ela à costa. Tal fim como este me dizia a mim meu espírito muitas vezes no Brasil, que ela havia de ter - e eu outras tantas a meus companheiros. Pelo que desejei muito de a deixar e passarmo-nos a algumas das seis ur-

80 Situada no litoral do atual Quênia, Mombaça abrigava uma fortaleza portuguesa erigida depois de a cidade ter sido destruída, no ano de 1539, por Nuno da Cunha.

81 Antiga designação da ilha de Creta evocativa de sua capital Cândia, atual Heraklion.

82 A advertência de Paulo ao centurião que o levava prisioneiro ("Senhores, vejo que a nossa viagem será desastrosa e acarretará grande prejuízo para o navio, para a carga e também para nossas vidas") está em Atos (27: 10).

83 A ilha de São Miguel no arquipélago dos Açores. A perda da "São Francisco" teria ocorrido em novembro de 1597 durante 0 ataque da grande esquadra inglesa comandada por Robert Deveraux, segundo conde de Essex (vide Hanes, 1923; Southey, 1837).

84 Episódio narrado por Marcos (11: 14): “E Jesus, falando, disse à figueira: Nunca mais coma alguém fruto de ti".

850 mesmo que romper as amarras (Leitão \& Lopes, 1974). 
cas flamengas que conosco partiram. Mas respeitos humanos, que muitas vezes obrigam e forçam as vontades a fazer contra o que julga o entendimento, obrigaram-me a não o fazer.

Logo em saindo do Brasil começou o novo leme (que ali fizemos) a mostrar, que assim como seu antecessor não quisera levar aquela nau à Índia, assim nem ele a queria - nem havia de trazer a Portugal - dando muitas pancadas e trazendo-a - em que lhe $p e z^{86}$ - por cima dos Abrolhos, baixos de que os Pilotos de Índia (e nós à ida) tanto tínhamos fugido, quando com a força dos [ventos] gerais ${ }^{87}$ (que pouco antes ou depois da Linha Equinocial se acham) são as naus lançadas da costa de África, a que até então vão arrimadas, para a do Brasil, que foi a causa do descobrimento daquela província, no ano de 1500, por uma armada em que ia por capitão-mor Pedro Álvares Cabral, a qual estes ventos empacharam para lá com mais força da que eles ordinariamente têm. Por cima dos quais tão temidos Abrolhos, ainda de longe, fomos nós correndo um dia com grandes sobressaltos do piloto, rompendo longas e contínuas manchas de ovas (segundo alguns diziam, do muito peixe que para aqueles baixos desova) que em forma de azeite - ou outra espessura - se estendiam por cima das águas ${ }^{88}$.

Continuando pois assim e indo sempre descaindo com o ímpeto dos [ventos] nordestes, cuja monção então é naquela costa, tornamos aos vinte e seis graus do sul, de onde tínhamos arribado, parte por força (como digo) e parte com vontade, para com volta tão larga dobrarmos francamente o cabo de Santo Agostinho (sobre o qual está situado o nosso colégio de Pernambuco) em oito graus da Linha [Equinocial] para o sul ${ }^{89}$, o qual dobramos aos quarenta dias depois que saímos da Bahia, espaço bem diferente do que uns padres nossos, que chegaram à nossa partida, gastaram nestas cem léguas que há de um colégio a outro, não pondo nelas mais que três dias.

O segundo domingo da quaresma, segundo de março do ano seguinte de [mil quinhentos e] noventa e sete, depois de Cristo Nosso Senhor se transfigurar a si, vendo quão pouco configurados a ele íamos todos os daquela nau, nos quis - à segunda-feira - transfigurar também a todos, mas não em glória, mandando-nos um [vento] norte tão furioso e uns mares tão grossos [...]

[...] Coisa mui diferente é o manati, a que nós chamamos peixe-boi; do qual vimos na cidade de Santo Domingo ${ }^{90}$ uma mãe e um filho vivos. Não tem mais semelhança de boi que uma pouca no focinho, tudo o mais é uma rudis indigestaque moles ${ }^{91}$. Só o filho podia dar

86 Antiga expressão portuguesa equivalente a "ainda que lhe custe", "a seu pesar" ou "a seu despeito".

87 São os alíseos que sopram do nordeste para 0 equador no hemisfério norte e do sudoeste para o equador no hemisfério sul (Monteiro, 1974).

88 Observação recorrente em vários documentos dos séculos XVI e XVII, esse fenômeno pode ter várias origens, derivando inclusive da proliferação de algas.

89 Na verdade esse colégio foi construído em Olinda, que realmente está a pouco mais de $8^{\circ}$ de latitude Sul. Vide nota 43.

90 Localizada na ilha de Hispaniola, atual capital da República Dominicana.

91 Em latim no original. Literalmente "massa confusa e informe", caracterização dada por Ovídio ao caos primigênio ("Chaos, rudis indigestaque moles") no primeiro livro das "Metamorfoses" (0vídio, 1916) de comer a um par de centos de homens e sobejar para convidar a outros poucos - e com ser tamanho ainda mamava, porque por não deixar a teta foi tomado também com a mãe. Coisa nova e muito de notar em peixe estranho, que eu nunca tinha lido nem ouvido de outro, porque diante de nós a estiveram ordenhando e tirando leite dela como se fora vaca. E muito mais nova e maravilhosa ainda [é] o lugar das tetas, que são os cotovelos dos braços, com singular advertência da natureza, que não falta no necessário, porque - pondo-lhas nos peitos - puderam mal servir aos filhos nadando a mãe e muito pior estando pastando, como ela costuma vir pastar junto à terra com os peitos sobre ela ${ }^{92}$. Conseguinte coisa ao leite deste peixe deve ser parir seus filhos já formados, que é também coisa rara em peixes e que eu não sabia mais do que dos tubarões que nós por vezes vimos, na costa da Guiné, abrir e lançar ao mar os filhos que dentro tinham (e eles irem logo nadando) do tamanho e feição de leitões, que alguns também comiam e tinham por tenro manjar.

Guisa-se este peixe-boi com tudo o que se lança em uma panela de vaca - e é tão semelhante sua carne que conosco trazemos, para nossa matalotagem, alguns barris dele salgado do Brasil e com o [que] comemos muitas vezes até Porto Rico. Todavia, dando-lhe aí fresco a dois padres que foram em missão pela ilha, pareceu a um deles que tinha obrigação, por ser sexta-feira, de dar (como deu) uma fraterna correção aos da casa em que estavam agasalhados, por comerem carne em sexta-feira, até que o desenganaram do que era e ele caiu em seu erro.

O mesmo me aconteceu a mim logo ao princípio não uma, mas algumas vezes, com a carne das tartarugas, estando à mesa do bispo da mesma ilha, onde elas vinham tão bem guisadas - e de tal maneira - que eu (por não Ihe dar outra fraterna [correção]), depunha com assaz trabalho o escrúpulo, parecendo-me que naquelas partes teriam os prelados mais largas dispensas. E assim a comia por carne, até que por tempo vim também a cair no que era93 $[\ldots]^{\prime \prime}$

\section{Transcrição atualizada das passagens geralmente atribuídas aos animais do Brasil no texto do jesuíta Gaspar Afonso (versão do Archivum Romanum Societatis Jesu segundo Lanciani, 1997)}

\section{“Pax Christi ${ }^{4}$}

[...] Navegando, pois, assim todas as naus em conserva entre ambas as fortunas até passada a Linha, sem mais outro alívio que os grandes rebanhos de peixe grande e pequeno que de dia, com grandes festas e danças, se-

92 Na verdade, os peixes-boi possuem duas pequenas mamas localizadas nas axilas, 0 "cotovelo dos braços" mencionado pelo autor.

930 consumo de carne e ovos de tartarugas nas sextas-feiras e na Semana Santa é um costume tradicional ainda observado no Brasil e em vários países da América espanhola. Nesse sentido, chama atenção a curiosa disputa envolvendo franciscanos e jesuítas no Maranhão seiscentista sobre a carne dos jabutis (Geochelone sp.) ser posta à mesa nos dias de abstinência (Amorim, 2005; Marques, 1996).

94 "Paz de Cristo", frase latina muitas vezes empregada como saudação entre várias ordens religiosas, sendo particularmente cara aos capuchinhos. 
guem a nau e com maiores e mais alegres de noite - para que em cada nau houvera de ir um Santo Antônio - nos começamos a apartar, como fazem todas por razão do mesmo interesse para chegar primeiro e vender mais caro, que foi causa de ficarmos sós sem quem nos desse a mão - de se cumprir em nós ao pé da letra aquilo Vae soli quia si ceciderit non habet sublevantem se ${ }^{95}$. E indo assim em demanda daquele grão cabo, com a artilharia já abatida no porão, como fazem todas as naus quando se sentem já vizinhas a ele, aprestadas para lutar com seus mares, chegando a 26 graus do Sul um dia à boca da noite com todas as velas dadas e elas cheias de todo o vento que podiam sofrer - que não seria pouco, pois só a de gávea com ser tão pequena tinha mil e seiscentas varas segundo o nosso mestre me disse - eis que subitamente quebra e desaparece o leme: e sei eu, por boa via, que a causa foi desobediência pura, que no mar e na terra sempre obra semelhantes efeitos. Já V.R. ${ }^{96}$ vê que noite aquela seria para a primeira meditação dos Novíssimos, cujo prelúdio foi uma confissão que todos fizemos por última desta vida ${ }^{97}$.

O dia seguinte - e alguns mais - se gastaram em deliberar sobre o remédio, que foram dois mastros - ou antenas $^{98}$ - por popa, a modo com que se governavam os barcos de Riba do Douro. E achado este, se gastaram outros tantos sobre a derrota que se tomaria, até final resolução que foi ir em demanda da Baía de Todos os Santos no Brasil, ainda que contra um expresso Regimento d'El Rei, tornando treze graus atrás, com temores cada hora de qualquer refrega de vento, assim porque o governo era fraco, como porque dando os dois mastros - que nos serviam de dois lemes por não se poderem subjugar ainda com bonança - grandes pancadas nos mais fraco da nau, com tempo forte em breve espaço a abririam. Mas foi Nosso Senhor servido de nos prosperar o tempo até à boca da baía, onde estivemos tão perdidos que havia quem não pedia a Nosso Senhor que o livrasse já de dar à costa, mas já que íamos dar nela, não fosse no calhau que tínhamos por davante, mas em uma pouca de areia que perto estava, onde sequer escapássemos com as vidas.

Até aqui as ocupações da nau - e depois à volta, enquanto ela deu lugar - eram confessar, dizer missa seca aos domingos e [dias] santos - que nestas naus se ouve com muita devoção e consolação, e para isto as provê El Rei a todas dos ornamentos necessários - ensinar a doutrina aos meninos (que são muitos) e pregar aos grandes. Em todos estes ministérios fez cada um dos 3 padres italianos muito, porque cada um deles tinha muito de Nosso Senhor, mostrando bem o espírito que os trazia e o ardente desejo que tinham de o dar a conhecer e fazer amar de todo o mundo: donde nasceu ao padre Jacome de Vicariis - já que o pregar havia de ser em português e estava à conta de um só que o era) - alcançar tão cedo de Nosso Senhor tal purificação (como aquela do cálculo ignito de Isaías) que em breves dias o fez, a quem seu

95 Vide nota 19.

96 Vide nota 23.

97 Vide nota 24.

98 Termo geral aplicado aos mastros e vergas sobressalentes (Leitão \& Lopes, 1974). muito espírito deixava entender de todos com dobrado gosto e amor. Porém, como os vagares e perplexidades com que andamos em dois climas tão ruins, saindo de um em que estávamos - que começava já a ser naquele tempo tão frio - e tornando a outro, que é sempre tão quente, junto com a malenconia universal, que em cada um tinha muitas causas gerais e particulares, adoeceu toda a gente sem escaparem mais que cinco de 460 pessoas que íamos - e entre eles o piloto, para ficarmos de todo sem governo material e racional, por não ficar outro igual a eles. Adoecemos nós também, todos [os] oito que íamos da Companhia [de Jesus] juntos - e tão gravemente que ao tomarmos mais tarde alguns dias porto, não sei quantos chegáramos ao colégio: donde nos vieram logo nossos padres e irmãos desembarcar em braços e levar em redes para casa, onde a poucos dias foi Nosso Senhor servido levar para si dois de nós no mesmo dia 27 de julho, scilicet ${ }^{99}$ o bom padre Jacome de Vicariis e o irmão João Sanches ${ }^{100}$; os mais quis guardar para mais trabalhos: Nos alia ex aliis in fata vocamur ${ }^{101}$.

O que desta terra - que foi a primeira estação das 7 que nesta romaria corremos - pudera escrever a V.R., terá V.R. lido em muitas [cartas] que nossos padres e irmãos de lá escrevem - e ouvido aos que de lá vem: e assim não sei eu que outra novidade mais aceita de lá escrevera que a muita caridade e mais que fraternal amor com que do padre reitor Inácio de Tolosa ${ }^{102}$ (a quem, por ser vivo, deixo de chamar santo, bênção própria dos Inácios em nossa Companhia) e dos mais padres e irmãos daquele colégio fomos recebidos, agasalhados, curados e regalados por todo o tempo que ali estivemos, que foram 5 meses menos 4 dias. Porém isto não se pode escrever por novidade, senão por antiguidade tão antiga na Companhia, ainda que por aquelas partes mui empinada.

O colégio é mui formoso e grande - assim no número dos sujeitos, padres e irmãos, como no edifício - com linda e curiosa vista sobre o porto, onde por 4 meses do ano são os irmãos recreados com contínua vista de muitas baleias - que ali por particulares respeitos seus se vem recolher e gastar em contínuas festas, saltos e danças, que não fora pouco impedimento do estudo se não fora tão contínuo: de que nós por nossa convalescença nos logramos assaz - além de outra vista que um dia com boa parte do colégio tivemos de uma nuvem descida sobre a água, de tal feição e postura de boca, pescoço e corpo - e com tal fervura ou sorvos de água para cima, que pus eu muita pouca culpa à ignorância daqueles que dizem que vêm elas beber ao mar. E depois desta, vimos no mar largo, bem perto da nau, outras 4 ou 5 juntas como esta ${ }^{103}$.

Temos uma quinta, que na verdura do arvoredo todo o ano, na muita água de fontes e [em] um mais lago que tanque com seu peixe, na fruta de espinho de toda a sorte e noutras - especialmente nos nunca assaz lou-

99 Em latim no original. Pode ser traduzida como "isto é"," "ou seja".

100 Vide notas 33 e 36.

101 Em latim no original. Frase de Enéias no terceiro livro da Eneida (Virgílio, 1999), a qual poderia ser traduzida como "nós fomos chamados para um outro destino".

102 Vide nota 37

103 Vide nota 40 
vados ananases - faz muita vantagem a Vila Franca de Coimbra ${ }^{104}$. Nem é de maravilhar de tanta frescura e viço da terra, onde só em cem léguas que há do colégio de Pernambuco ao da Bahia - me disse o padre provincial - que passavam quarenta rios tão caudalosos, que nem em jangadas se podiam passar os 20 senão de maré vazia, posto que as verdadeiras causas desta frescura em toda a tórrida zona são mais superiores.

Ali vimos o animal preguiça - de cuja preguiça será pouco tudo o que V.R. poderá cá ter ouvido - de que a terra é tão provida (mal pecado em toda parte) que não foi necessário mais que mostrar eu em uma aldeia nossa desejo de ver um, para me trazerem logo dois. Coisa é molestíssima ver o tempo que há mister para andar 4 passos: e assim não tem necessidade de prisão, porque sua própria preguiça o é bastantíssima, pois nem para fugir de ameaças da morte dá um passo mais apressado. $E$ ainda que tem grandes mãos e pés - e mui disformes unhas de comprimento de um dedo - sempre leva o corpo a rastos, porque os pés e mãos não se cansem de o trazer às costas com não ser maior que o de uma raposa, antes menos alguma coisa.

Vimos outro animal a quem os brasis chamam tatu, a quem a natureza armou de caçolete, espaldar, coxetes, manoplas e todas as mais peças com que a arte depois aprendeu a armar um homem de ponto em branco ${ }^{105}$.

Vimos mais uns passarinhos, que depois de se enfadarem de ser borboletas e de viver em tão baixo e tão imperfeito estado, se passam a outro mais alto e mais perfeito, fazendo-se passarinhos muito lindos e de cores mui louçãs - de que há muitos na nossa quinta - que no modo de voar e tomar pouso não podem, todavia, encobrir quem foram em outro tempo. Cuja metamorfose crerá facilmente quem crer a do cão do Japão, que enfadado também de ser cão na terra, se vai também a seu parecer melhorar e fazer peixe ao mar, que eu vi e tive nas mãos, com a metade da conversão feita, em Lisboa pouco antes do Padre Rodrigo Soares ${ }^{106}$ se partir para a Índia: o que parece ser mais, porque aquele [passarinho] não muda mais que a natureza e este [cão muda] natureza e elemento ${ }^{107}$.

Das letras e habilidades dos bugios se sabe cá pouco e muito menos de seus sermões e exortações, não sei se espirituais ou temporais, sendo acompanhados ao púlpito, honoris gratia ${ }^{108}$, de dois ministros que servem, durante o sermão, de lhe estar alimpando a baba que - com o muito zelo, fervor e corrente de palavras - Ihe cai da boca, sem faltar mais que vestir-lhe no cabo uma camisa, afora outras mil coisas suas desta qualidade. Entre eles há alguns de cheiro, louros e mui formosos. Lembra-me que dizia o irmão Fulgêncio Freire que vira no mar Roxo alguns tamanhos como mulas - nós vimos outros aqui no Brasil tamaninos como ratos.

104 Trata-se da Quinta de Vila Franca, residência de verão dos jesuítas do colégio de Coimbra. Localizada nas margens do rio Mondego, teria sido doada pela Coroa em 1571.

105 Vide nota 48

106 Natural de Arouca, o padre Rodrigo Soares teria viajado para a Índia em 1576, falecendo nesse mesmo ano (Franco, 1719).

107 Vide nota 50

108 Em latim no original. No caso, tal expressão poderia ser traduzida como "por uma questão de honra" ou "em virtude do cargo".
Deixo as cobras que tragam um veado, que se não foram tão dobradiças podiam servir ou de mastaréus nas naus ou de traves nas casas. Posto que os da terra as têm por mais proveitosas cozidas ou assadas na mesa, como também fazem aos lagartos, que lá são mui monstruosos. Os camaleões, que têm alguma figura de lagartos, são também muito maiores que os que eu tenho visto em África.

Os índios conservam ainda algumas propriedades do estado da inocência, como terem por escusado o vestido ainda dentro nas nossas cidades, [algo] que os portugueses não notam por lhes ser coisa tão natural e contínua. Vivem muitos em umas grandes casas de que tem cada povo dez, doze ou mais, conforme a gente, sem chaves, nem arcas, nem memória de fechar ninguém suas coisas porque outro lhas não furte.

O recebimento dos hóspedes - e primeira mostra de prazer logo em chegando, como me a mim fizeram em uma destas aldeias - é um pranto desfeito das mulheres chorando, contando todos os trabalhos e perigos que poderíamos ter passado. Acabado isto e enxutas as lágrimas, com a brevidade com que elas se enxugam quando não se derramam mais que pro forma ${ }^{109}$ (porque lachryma nihil citius ares $c^{1{ }^{110}}$ ) se segue todo o mais verdadeiro gasalhado e festa que nós cá fazemos aos nossos hóspedes.

Coisa é muito para ver um alarde seu e forma de sua guerra - de que deram uma alegre vista defronte de nosso colégio a gente de 3 aldeias, que por ocasião de inimigos franceses vieram guardar um passo. Com tudo fazem pavor e espanto ao inimigo: com as plumas, com a grita, com os saltos em que são ligeiríssimos e contínuos enquanto dura a batalha, sem darem lugar para se fazer neles pontaria nenhuma. Na grandeza dos arcos e força das setas, tamanha que - ainda que o bico é de pau vimos nós uma que o capitão da nossa nau comprou a um índio para trazer e mostrar, por lhe ver passar com ela juntamente duas tábuas de uma porta - de não sei quantos dedos - de um tiro. Exortam-se a estas guerras - e a outras coisas a que de communi ${ }^{111}$ hão de acudir todos os do povo - com pregações que fazem de noite, andando o pregador pelas ruas rodeando as casas, que é o que melhor linguagem e corrente tem. Ouvi eu algumas, estando entre eles, com grande fervor e eficácia para persuadir.

Na guerra e na caça são tão destros que sem a pontaria com o olho que nós fazemos - antes rindo-se muito disso - não erram um passarinho, como eu vi a um derrubar muitos, um após outro: entre os quais matou a um que tinha a língua como dois dedos maior que o bico, que me deu bem em que cuidar, porque como Deus e a natureza não façam coisa nenhuma por demais, não sabia para que poderia servir esta senão para símbolo dos que falam demasiado.

Em uma destas aldeias recebi estranha consolação, vendo às horas de aves-marias ordenar os meninos à

109 Em latim no original, ou seja, "por formalidade".

110 Em latim no original. Frase do primeiro livro das "De inventione" de Cícero (1949), a qual poderia ser traduzida como "nada seca mais rápido que uma lágrima".

111 Em latim no original, ou seja,"comum","comumente". 
porta de nossa igreja - conforme a ordem que de nossos padres têm para o fazer cada dia - [e fazer] uma procissão até à cruz, que está um pedaço fora, cantando a doutrina: entoando dois e respondendo os outros - de que eu não entendia mais que Jesus e Maria - com tanta devoção e ordem que não é necessário na procissão quem governe. E se a compostura dos meninos na procissão é muita, nada menos o é a dos pais e mães na igreja, onde todavia trabalham de vir mais cobertos e estar atentíssimos à missa e pregação, que em sua língua lhe vi fazer um irmão nosso com muita graça.

Antes de contar um caso dos tempos que aí estivemos, tocarei outro mais antigo alguns anos, porque para mim foi também novo quando o lá ouvi - e assim o será para outros: o qual sucedeu ao Padre Morinello, italiano, e Manoel Viegas, português ${ }^{112}$, na praia de Piratininga, tal que só sua feia pintura - que nos mostraram - faz pavor a quem a olha. Indo pois os padres ambos e dois meninos índios por uma praia, Ihes apareceu diante um fantasma ou figura de homem, negra com as costas e entranhas ardendo em fogo, com um passo vagaroso como quem os ia esperando: até que enfim chegaram e cuido que lhe falaram. Depois se foi aquela figura andando para o mar, donde saíram alguns negrinhos e indiozinhos a o receber - e ferrados dele o foram metendo até desaparecer. Custou a visão bem a ambos os padres. Para a interpretação que alguns dão a este enigma, suponha V.R. a injustiça com que alguns portugueses, naquela província, fazem entradas pelo sertão a trazer índios para suas fazendas que tem cá ao longo do mar, causa da antiga contenda e encontros que sobre isso eles com nossos padres têm por lho impedirem.

Dizem pois alguns intérpretes das figuras ser este uma afamada cabeça destas entradas, que havia pouco que por ali junto era falecida. E que quis Nosso Senhor assim mostrar que os índios, que ele ia buscar e trazer do sertão para o mar, lhe levaram a alma para aquele lago e mar infernal. E com tudo isto não quer a avareza desistir desta empresa: antes - estando nós lá - andava no sertão uma grande expedição de soldados para o mesmo efeito: naquele de enfermidades morreram muitos e se tornaram os que escaparam com o gasto feito e sem proveito, porque nem um só [índio] trouxeram nem acharam. O que tudo o Padre Reitor Inácio de Tolossa Ihes tinha no púlpito prognosticado, ou profetizado, antes de partirem, trabalhando de os dissuadir de tão injusta guerra e empresa. E foi permissão divina porque, acabando eles de chegar, chegaram nas suas costas os principais de vinte e cinco mil almas, que lhes não ficaram mui longe, buscar padres nossos para que os fossem trazer e meter no rebanho daquele grande e bom Pastor, que por serem suas as encobriu e livrou dos lobos que com tanta sede as buscavam.

Igual gosto pode dar um milagre do bem-aventurado Santo Antônio, por ser coisa do nosso tempo - ao menos no castigo de forca que se deu a muitos franceses, estando nós aí, por terem dado ocasião ao milagre. Já V.R. saberá como, pouco antes de partirmos de Lisboa o ano

112 Vide notas 65 e 66. atrás de [15]95, tinham alguns navios franceses saqueado o nosso Castelo de Arguim - que está junto ao cabo Branco contra a costa da Guiné113. E pouco contentes com as afrontas que fizeram aos santos em suas imagens na terra, embarcaram consigo em uma das naus um Santo Antônio de vulto de boa estatura para se recrearem no mar, metendo-lhe - como metiam - um broquel no braço dizendo que se defendesse. E assim jogando com o santo as cutiladas, o encheram de muitas feridas. Coisa maravilhosa: que com o santo aprender e usar tão pouco esta arte em sua mocidade pelas ruas de Lisboa, onde com tanta quietação se criou, se muitas recebia no corpo cá em cima no convés da nau, em cuja praça se fazia a festa, muito mais cruéis lhas dava lá por baixo no paiol, no biscoito, na carne e na água e pelos arcos das pipas, fazendo-Ihe apodrecer um e derramar o outro sem o eles saberem. Até que cansados e enfadados das festas o lançaram ao mar, fazendo sua derrota para o Brasil para nele continuar com sua pilhagem. Se não quando a poucos dias se acharam sem mantimentos nem água, de maneira que uma das naus, forçada da extrema necessidade, se foi entregar voluntariamente ao governador da Bahia, que por se entregarem ficaram depois com as vidas até nossa partida. Outros, querendo-se prover pela costa à força de armas, desembarcaram em duas partes diversas e em ambas foram tomados e depois enforcados na cidade. E porque soubessem eles muito bem que assim se sabia Santo Antônio defender e ofender, ao tempo que vinham trazendo uma destas esquadras presa para a cidade por uma grande e comprida praia, viram ao longe um vulto e indo andando e chegando-se mais, Ihes ia parecendo homem. E chegando de todo acharam ser o mesmo Santo Antônio com suas feridas, que eles tinham acutilado e lançado ao mar, que os estava ali esperando não deitado mas em pé: cuja vista assim e naquela postura causou, segundo me disseram, um grão sobressalto e pavor aos franceses. Parece que lhes quis o santo dizer, vindo-os esperar ali, que ele os trazia e que para serem agasalhados como eles mereciam - e em efeito o foram - tinha ele vindo por seu aposentador diante. E está agora esta imagem em uma igreja de capuchinhos, curada já de suas feridas, que nós vimos com muita consolação nossa por vezes, tão venerada como ela merece.

E com isto nos saímos do Brasil e demos à vela para onde Nosso Senhor for servido, incerti quo fata ferant, ubi sistere detur ${ }^{114}$. Como saímos, ainda que contra o parecer de uma celebérrima feiticeira daquela cidade, a qual em São Francisco ${ }^{115}$ disse à mulher de um capitão de Mombaça ${ }^{116}$, que na nossa nau ia, que se não embarcasse outra vez nela, porque a nau não havia de ir a Portugal, como nos a mesma senhora bem temerosa lá disse, coisa que o espírito com que aquela má profetisa se comunica - sendo tão bom calafate na praxe e tão bom astrólogo na especulativa - podia muito bem naturalmente saber,

113 Vide nota 68

114 Vide nota 79

115 Ao contrário do que afirmam alguns (e.g., Lanciani, 1997), a versão mais extensa da carta de Gaspar Afonso deixa claro ser esta uma referência à igreja de São Francisco e não à localidade de São Francisco do Conde.

116 Vide nota 80 
pois não foi castigado mais que no gratuito. Bem é verdade (pondo à parte e não fazendo nenhum caso disto, como era bem que nós não fizéssemos) que por outra parte via eu o formal e o material da nau de maneira que - sem o espírito de São Paulo, mas com o seu temor - dizia antes de partirmos, muitas vezes, "video quoniam cum injuria multo damno non solum oneris et navis sed etiam animarum nostrarum incipit esse navigatio"117: como na verdade o foi, morrendo muita gente e perdendo-se enfim de todo a nau sem chegar a Portugal. Pelo que desejei muito de nos passarmos a algumas de seis urcas flamengas que conosco partiram - acuso-me gravemente que não me tiraram disso mais que respeitos humanos, como muitas vezes disse a meus companheiros.

Logo em saindo do porto, começou o novo leme que ali fizemos - a mostrar que assim como seu antecessor não quisera levar aquela nau à Índia, assim nem ele a queria nem havia de levar a Portugal, dando muitas pancadas na nau e trazendo-a, em que lhe pez ${ }^{118}$, por cima dos Abrolhos - de que os pilotos da Índia e nós à ida tanto tínhamos fugido, quando com a força dos [ventos] gerais são as naus lançadas da costa de África para a do Brasil, que foi a causa do descobrimento daquela província por uma nau da Índia - por cima dos quais fomos correndo um dia com grão medo do piloto, rompendo longas e contínuas margens de ovas (diziam alguns) do peixe que por aqueles baixos desova.

Continuando assim e indo sempre descaindo com o ímpeto dos [ventos] nordestes, cuja monção então é naquela costa, tornamos aos 26 graus do sul, donde tínhamos arribado parte por força - como digo - e parte por vontade, para com volta tamanha passarmos bem largos do cabo de Santo Agostinho onde está o colégio de Pernambuco, que dobramos ao quadragésimo dia, espaço bem diferente do que uns padres nossos acabavam de gastar à nossa partida, não pondo de um colégio a outro mais que três dias ${ }^{119}$.

O segundo domingo da quaresma, dois de março do ano seguinte de [15]97 depois de Cristo Nosso Senhor se transfigurar a si, vendo quão pouco configurados a ele nós íamos todos os daquela nau, nos quis - à segunda-feira - transfigurar também a todos, mas não em glória, mandando-nos um [vento] norte tão furioso e uns mares tão grossos [...]

[...] Coisa mui diferente é o peixe-boi, a que eles por lá chamam manatim, do qual vimos na cidade de Santo Domingo uma mãe e um filho vivos: não tem mais semeIhança de boi que uma pouca no focinho, coetera rudis indigestaque moles ${ }^{120}$. Podia o filhinho dar de comer um par de dias a este colégio e sobejar para mandar a outro - e contudo ainda mamava, porque por não deixar a teta foi tomado também com a mãe: coisa bem particular em peixes, porque diante de nós se estava tirando leite dela como o de qualquer vaca ordenhando e tirando leite dela como se fora vaca - e mais particular ainda o lugar das tetas, que são os cotovelos dos braços, com singular

\footnotetext{
117 Vide nota 82

118 Vide nota 86

119 Vide nota 89.

120 Vide nota 91
}

advertência da natureza, porque pondo-Ihas nos peitos puderam mal servir aos filhos nadando a mãe e muito pior estando pastando, junto ou sobre a terra, com os peitos nela, como ela costuma. Conseguinte coisa ao leite deste peixe deve ser parir seus filhos já formados, que é também coisa rara neles e que eu não sabia mais do que dos tubarões, que nós por vezes na costa da Guiné vimos abrir e - lançados os filhinhos como caçõezinhos ou litões ${ }^{121}$ ao mar - ir logo nadando, que alguns também comiam e tinham por tenro e delicado manjar. Guisa-se este peixe-boi com tudo o que se lança em uma panela de vaca - e é tão semelhante sua carne que conosco trazemos alguns barris dele salgado do Brasil e o comemos muitas vezes até Porto Rico. todavia, dando-lho aí fresco uma sexta-feira a dois padres que foram em missão pela ilha, pareceu a um deles que tinha obrigação de dar como deu - uma fraterna correção na casa onde se lhe dava por comer carne em sexta-feira, até que o desenganaram do que era e ele caiu em seu erro.

O mesmo me aconteceu a mim logo no princípio não uma, mas algumas vezes, com as tartarugas, estando à mesa do bispo da mesma ilha onde elas vinham guisadas de maneira que eu, por lhe não dar outra fraterna [correção], depunha com assaz de trabalho o escrúpulo, parecendo-me que naquelas partes teriam os prelados mais largas dispensas e em mais casos: e assim a comia por tal, até que por tempo vim a cair também no que era'122 [...]"

\section{OS ANIMAIS MENCIONADOS}

\section{Dos insetos}

A única citação de um inseto brasileiro encontrada diz respeito ao proverbial bicho-do-pé, Tunga penetrans (Linnaeus, 1758) (Siphonaptera, Hectopsyllidae), praga bem conhecida que é descrita por Gaspar Afonso como "uns bichinhos [...] invisíveis em seu nascimento" dos quais "não se dá fé senão depois que pegados nos dedos dos pés sobre as unhas - e comendo neles delicadissimamente como ouções, vêm a crescer e fazer-se às vezes tamanhos como camarinhas ou grãos de aljôfar, porque tais parecem eles quando os tiram daquelas celas que cada um lavra para si sobre o dedo". Tendo chamado a atenção de vários outros cronistas do século $\mathrm{XVI}{ }^{123}$ as infestações do bicho-do-pé podiam constituir um sério problema, levando até mesmo a amputações ${ }^{124}$.

\section{Dos peixes}

Até o momento em que chegou ao Brasil, Gaspar Afonso mencionaria cinco peixes distintos observados em alto mar, passagem reproduzida em várias publicações mais recentes ${ }^{125}$. No entanto, a maior parte desse re-

\footnotetext{
121 Provável erro de transcrição, pois a versão mais extensa da carta de Gaspar Afonso fala de "leitões".

122 Vide nota 93.

123 Por exemplo Léry (1578) e Staden (1557).

124 Vide Guyon $(1865,1866,1867,1868,1869)$.

125 Por exemplo em Mello-Leitão (1946) e Miranda (2004).
} 
lato parece ter sido efetuada durante a rota da nau "São Francisco" para o cabo da Boa Esperança, portanto antes do acidente que forçaria a embarcação buscar refúgio na Bahia. Na verdade, a única referência indubitável ao nosso país pertence aos comentários muito gerais fornecidos sobre os tubarões (Chondrichthyes, Selachimorpha), cujos dentes seriam "tão fortes e tão agudos que servem aos brasis [i.e., aos indígenas] de ferros em suas flechas". Conforme já foi estabelecido por Nomura (1996), não é possível estabelecer quais espécies teriam sido observadas.

Algo semelhante pode ser dito da "manchua", "um peixinho muito miúdo que o autor da natureza por aqueles campos cria em grande abundância", pois semelhante denominação - assim como as variantes "manchuva", "manchuba"e"manjua" - diz respeito a diversos representantes dos Clupeidae e Engraulidae (Clupeiformes) mais conhecidos nos dias de hoje como"manjubas"126. Do mesmo modo, a descrição dos "voadores" poderia ser atribuída a qualquer Exocoetidae (Beloniformes) do Atlântico, malgrado Nomura (1996) tenha sugerido tratar-se de Exocoetus volitans Linnaeus, $1758^{127}$. Para finalizar, Gaspar Afonso fala de "uns peixinhos muito pintados", chamados "romeiros", que "se encostam aos tubarões, sustentando-se de suas migalhas" e"sentem-se tão obrigados por esta esmola que preso ele se prendem eles, ferrados em suas costas". Sem dúvida alguma, a última parte desse trecho refere-se a alguma rêmora (Echeneidae, Perciformes) impossível de ser identificada, mas mesmo assim atribuída a Echeneis naucrates Linnaeus, 1758 por Nomura (op. cit.). A exemplo de outros, esse autor comete o equívoco de associar esse Echeneidae ao nome "romeiro", termo até hoje empregado em Portugal para o peixe-piloto, Naucrates ductor (Linnaeus, 1758), um Carangidae (Perciforme) listrado de negro bem mais adequado à descrição de "um peixinho muito pintado". Na verdade, o texto original é confuso e sugere que o próprio jesuíta teria confundido ambas espécies.

\section{Dos répteis}

O original menciona três répteis diferentes, a começar pelas indefectíveis cobras gigantescas "de quarenta palmos de comprido, a que os índios chamam jiboias, que se não foram tão dobradiças podiam servir de mastaréus nas naus, ou de traves nas casas", as quais "tragam estas um veado inteiro sem se lhe atravessar na garganta nem um ossinho de toda sua armação", crença que permanece viva na imaginação popular até os dias de hoje. Embora a sucuri, Eunectes murinus (Linnaeus, 1758) tenha sido assinalada do sul da Bahia ao Ceará e Piauí128, Gaspar Afonso parece estar se referindo à jiboia, Boa

126 Vide nota 12.

127 Apesar de os estudiosos do Renascimento não desconhecerem Cheilopogon heterurus (Rafinesque, 1810), os peixes-voadores tropicais despertaram enorme interesse, sendo considerados autênticos "prodígios" dignos da atenção de cosmógrafos, cronistas, médicos e cartógrafos renomados Entre outros, exemplos nesse sentido podem ser observados nos trabalhos de Linschoten (1596); Ortelius (1570); Oviedo y Valdés (1535); Paré (1585) e Thevet (1575). Notícias imprecisas sobre peixes-voadores poderiam estar na origem do "serra", um fabuloso peixe de tamanho gigantesco e asas emplumadas descrito por Alberto Magno e tantas outras fontes do medievo (vide Kitchell Jr. \& Resnick, 1999; Mermier, 1992; White, 1954).

128 Vide Freitas \& Silva $(2005,2007)$ e Silva-Leite et al. (2010). constrictor (Linnaeus, 1758) (Boidae) e não à Eunectes murinus, conforme pretende Nomura (1996). Mesmo considerando que os couros das serpentes distendem-se com facilidade e acabam por superar por larga margem o tamanho dos exemplares vivos, o valor de "40 palmos" (em torno de 8,8 metros) parece excessivo, pois as jiboias usualmente não ultrapassam os 4 metros e não existem casos comprovados de sucuris com mais de 8 metros de comprimento ${ }^{129}$.

Tal como essas serpentes, caçadas pelos índios como "singular iguaria", a "carne dos lagartos, que lá são monstruosos, a que eles chamam jacarés" era bastante apreciada inclusive pelos portugueses, provável alusão ao jacaré-de-papo-amarelo, Caiman latirostris (Daudin, 1802) (Alligatoridae), conforme já foi proposto por Nomura (1996). A derradeira citação, entretanto, limita-se a falar dos"camaleões, que têm alguma figura de lagartos e são também muito maiores que os que eu tenho visto em África e em Mazagão, onde estive", uma clara referência ao camaleão-comum, Chamaeleo chamaeleon (Linnaeus, 1758), espécie mediterrânea que pode alcançar até 40 $\mathrm{cm}$ de comprimento (Figura 4). No caso, deve tratar-se de Iguana iguana (Linnaeus, 1758) (Iguanidae), pois esse réptil continua sendo chamado de "camaleão" em diversas partes do Brasil (vide também Nomura, op. cit.).

\section{Das aves}

O texto faz alusões genéricas aos "pássaros marinhos", individualizando apenas certos "teijões", os quais devem ser os mesmos "feijões" descritos por alguns pilotos (e.g., Manuel Álvares e Vicente Rodrigues in Albuquerque, 1969, e Costa (A. F. da), 1940b) como uma ave marinha "pequena, da feição de pegas pintadas". Em seu célebre "Itinerário", Jan Huygen van Linschoten (1596), também mencionaria os "feigions" dos portugueses como "pintalgadas de marcas brancas e negras", enquanto Gaspar Ferreira Reimão (1612) fala dos "feijões" como "umas aves pequenas como pombas, marchetadas de preto e branco"130. Trata-se evidentemente da pomba-do-cabo, Daption capensis (Linnaeus, 1758), que se encontra bem caracterizada pelo padrão alvinegro da plumagem.

Mais adiante, Gaspar Afonso falaria de "uns passarinhos que depois de se enfadarem de ser borboletas e de viver em tão baixo e tão imperfeito estado, com desejo de subir e valer (que até nos brutos parece que reina), se passam a outro mais alto e mais perfeito, fazendo-se passarinhos muito lindos e de cores mui louçãs de que há muitos na nossa quinta, que no modo de voar e tomar pouso não podem, todavia, encobrir quem foram em outro tempo". Além de não trazer qualquer descritivo, essa passagem apenas reafirma a crença de os beija-flores (Trochilidae) nascerem de borboletas, fábula aceita e repetida por diversos membros da Companhia de Jesus ${ }^{131}$,

129 Murphy \& Henderson (1977).

130 Joaquim Heliodoro da Cunha Rivara (in Laval, 1858), comenta haver na região do cabo da Boa Esperança "outro passaro branco também branco, e com as pintas pretas, de que ha grande multidão, e ao qual [...] chamam os navegantes portugueses Feijão frade", uma Fabaceae igualmente branca pintalgada de preto.

131 Por exemplo Anchieta (1933); Cardim (1939) e Vasconcellos (1663). 
conforme bem comprova o fato de um provincial da ordem ser a origem da divulgação dessa lenda pela Europa levada a cabo pelo naturalista Charles L'Écluse (1605). Finalizando, acrescentaria breve comentário sobre outro "passarinho" com "a língua como dois dedos maior que o bico", detalhe que evoca algum pica-pau (Picidae), pois essas aves podem ser facilmente tratadas como "passarinhos" e possuem uma língua vermiforme bastante longa capaz de atingir cinco vezes o tamanho do bico ${ }^{132}$.

\section{Dos mamíferos}

Por ter sido levado a cabo na baía de Todos os Santos durante o mês de julho, entre outros pormenores, o testemunho de Gaspar Afonso sobre as baleias alinha-se aos escritos de cronistas dos séculos XVI e XVII como Gabriel Soares de Sousa (1938) e Frei Vicente do Salvador (1889), os quais tecem observações análogas em geral atribuídas aos jubartes, Megaptera novaeangliae (Borowski, 1781), espécie costeira bem conhecida por seus espetaculares saltos acrobáticos ${ }^{133}$. Em outro momento, ao descrever os peixes-bois encontrados no Caribe, Trichechus manatus Linnaeus, 1758, o autor menciona ter levado "para nossa matalotagem, alguns barris dele salgado do Brasil [i.e., da Bahia] com [os quais] comemos muitas vezes até Porto Rico", assertiva que reforça o texto de Gabriel Soares de Sousa (op. cit.) sobre os peixes-bois dessa mesma espécie abatidos na baía de Todos os Santos ${ }^{134}$. Este parece ter sido um recurso corrente, pois uma carta do padre Antônio Vieira a Afonso VI, datada de novembro de 1659, assinala que mais de 20 navios holandeses, carregados com a carne de peixe-boi salgada, partiam todos os anos do cabo do Norte, Amapá, para a Europa ${ }^{135}$.

$\mathrm{O}$ texto também registra alguns poucos mamíferos terrestres em termos muito vagos para permitir uma identificação. Esse é o caso do tatu (Dasypodidae) e da preguiça (Bradypus sp.), descritos como um animal couraçado de todas as "peças com que a arte depois aprendeu a armar um homem" e um ser indolente com pés e mãos providas de unhas "mui disformes" com o "comprimento de um dedo". Malgrado Bradypus torquatus Illiger, 1811 e Bradypus variegatus Schinz, 1825 tenham sido assinaladas para o recôncavo baiano, esta última costuma aparecer com maior frequência nos relatos quinhentistas.

De certa forma, o mesmo ocorre com os "bugios", palavra empregada pelo jesuíta para nomear os primatas

132 Vide Portmann (1950) e Sick (1984).

133 Vide C.M.R. da S. Brito (2009) e Hetzel \& Lodi (1993).

134 Esse exato trecho de Gaspar Afonso faria parte da argumentação arrolada na "Memória sobre a pesca das baleias" de José Bonifácio de Andrade e Silva (1790). Esses mamíferos aquáticos parecem ter sido de fato bastante comuns em nosso litoral, pois ao descrever os dugongos das Molucas no ano de 1569, Gabriel Rebello mencionaria ter o"peixe vaca mui estranha feição e grandeza, do qual não trato por ser muito conhecido dos do Brasil, que são os próprios, sem diferir, segundo dizem" (in Sá, 1955).

135 "Chegou finalmente 0 anno passado de 16560 Gouernador D. Pedro de Mello com as nouas da guerra apregoada com os Olandeses, com os quaes alguma das naçoens dos Nheengaíbas ha muyto tempo, tinham commercio, pela vizinhãça dos seus portos com os do Cabo do Norte, em que todos os annos carregam de peixe boy mais de vinte nauios de Olanda" (Vieira, 1660). Da mesma forma, um dos personagens do "Diálogo sobre a conversão do gentio" - escrito na Bahia pelo padre Manuel da Nóbrega entre 1556 e 1557 - cofessa soa ignorância acerca dessa questão por "andar na água aos peixes-boi e no mato com o brasil" (Leite, 1955). em geral, pois haveria alguns "de cheiro, louros e mui formosos, que em lhe mudando os ares morrem logo, por isso chegam cá poucos" e outros "tamaninos como ratos", prováveis referências ao mico-leão dourado, Leonthopithecus rosalia - o qual era levado tanto para Salvador quanto para a Europa durante o século XVI136 e algum um outro Callitrichidae, talvez Callithrix penicillata (É. Geoffroy, 1812), caso se considere o fato de o jesuíta português aparentemente não ter se afastado dos arredores da cidade. Esse mesmo motivo permite atribuir boa parte do texto sobre os "bugios" a Allouatta guariba (Humboldt, 1812) do Brasil oriental, embora o autor se limite a veicular a conhecida fábula de a grande gritaria dos guaribas ser conduzida graças aos esforços de um "chefe" - chamado de "capelão" pelo vulgo - que baba pelos cantos da boca e tem a saliva limpa com folhas pelos outros membros do bando. Presente até os dias de hoje, essa lenda foi mencionada por outras fontes do Brasil Colônia ${ }^{137}$.

\section{DISCUSSÃO}

O texto de Gaspar Afonso contém 18 referências geralmente associadas à fauna brasileira, as quais compreendem um inseto, três répteis, quatro aves, cinco peixes e cinco mamíferos (Tabela 1). Desse elenco, o possível registro de um mico-leão visto pelo jesuíta na Bahia e a assertiva da carne salgada dos peixes-bois ser usada na matalotagem dos navios revelam-se os mais interessantes, respaldando os comentários de Gabriel Soares de Sousa (1938) sobre o tráfico interno de animais silvestres em pleno século XVI, além de reforçar a conjetura de os sirênios terem sido muito comuns e aparentemente tão

Tabela 1. Animais usualmente atribuídos ao brasil mencionados pelo jesuíta Gaspar Afonso (1596).

\begin{tabular}{ll}
\hline REFERÊNCIA & IDENTIFICAÇÃo PROPOSTA \\
\hline "Tunga" & Tunga penetrans \\
"Tubarão" & Selachimorpha não identificado \\
"Manchua" & Clupeidae ou Engraulidae não identificado \\
"Voador" & Exocoetidae não identificado \\
- & Echeneidae não identificado \\
"Romeiro" & Echeneis naucrates \\
"Jiboia" & Boa constrictor \\
"Jacaré" & Caiman latirostris \\
"Camaleão" & Iguana iguana \\
"Teijão" & Daption capensis \\
"Passarinho" & Trochilidae não identificado \\
"Passarinho" & Talvez um Picidae \\
"Baleia" & Provavelmente Megaptera novaeangliae \\
"Preguiça" & Talvez Bradypus variegatus \\
"Tatu" & Dasypodidae não identificado \\
"Bugio" & Provavelmente Allouata guariba \\
"Bugio do tamanho de ratos" & Talvez Callithrix penicillata \\
"Bugio de cheiro louro" & Provavelmente Leonthopithecus rosalia \\
"Peixe-boi" & Trichechus manatus \\
\hline
\end{tabular}

136 Vide Teixeira \& Papavero (2010).

137 Vide Ferreira (1972) e Papavero, Teixeira \& Chiquieri (2011). 

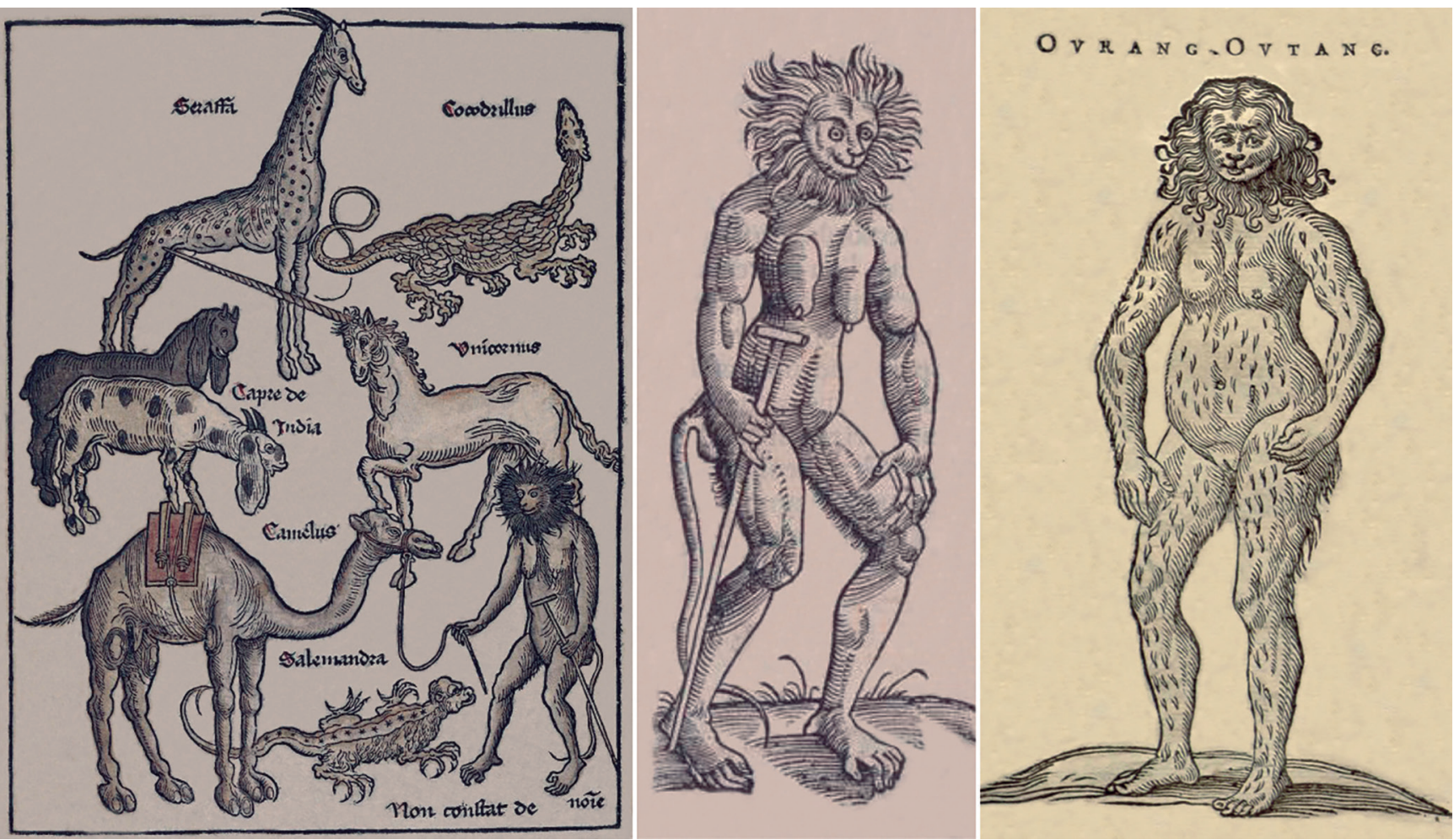

Figura 5. Da esquerda para a direita: os animais da Terra Santa segundo as "Peregrinationes in Terram Sanctam" de Bernhard von Breydenbach (1486), 0 "sátiro" da "Historia Animalium" de Conrad Gesner (1551) e o"orang-outang" da "Historiae Naturalis \& Medicae Indiae Orientalis" de Jacobus Bontius (in Piso, 1658).

perseguidos quanto as baleias do recôncavo baiano durante esse mesmo período.

Embora não diga respeito ao nosso país, o relato sobre a viagem da nau "São Francisco" também abriga uma passagem assaz desconcertante relativa a um comentário feito pelo jesuíta Fulgêncio Freire em Lisboa: "lembra-me que dizia o irmão Fulgêncio Freire - quando por este Reino veio do Cairo, [para] onde fora levado cativo [no momento em que estava] tornando para a Índia - que vira no mar Roxo [i.e., no mar Vermelho] alguns [macacos] tamanhos como mulas"138. Embora se coadune com os fatos históricos conhecidos - Fulgêncio Freire esteve na "Etiópia" em 1555 e 1560139 - trata-se de uma declaração sobremodo inusitada, pois a descrição de um primata com tal porte imediatamente evoca um orangotango, Pongo sp., ou um gorila, Gorilla sp., pois os machos adultos de Pongo pygmaeus (Linnaeus, 1760) podem chegar a 1,4 m de comprimento e $100 \mathrm{~kg}$ de massa corporal, enquanto aqueles de Gorilla beringei Matschie, 1903 - o maior antropóide vivo - alcançam 1,7 m e $200 \mathrm{~kg}$.

A assertiva de que os árabes só conheciam determinadas espécies da família Cercopithecidae ${ }^{140}$ contrasta

138 "Lembrame que dizia o Irmaõ Fulgencio Freire; quando por este Reyno veyo do Cairo, tornando para a India, donde fora levado lá cativo, que vira no mar Roxo alguns tamanhos como mulas" no original (vide Gaspar Afonso in B.G. de Brito, 1735-1736).

139 Fulgêncio Freire era feitor de Baçaim quando decidiu entrar para a Companhia de Jesus como coadjutor móvel, posição que manteve apesar dos rogos de seus superiores. Em 1555, acompanhou o padre Gonçalo Rodrigues quando este partiu com o embaixador Diogo Dias, enviado pelo Vice-Rei Pedro de Mascarenhas à Etiópia. Voltaria àquele império em 1560, tendo sido feito prisioneiro por quatro galés turcas comandadas pelo pirata Cofar. Mantido prisioneiro no Cairo, conseguiu ser resgatado em 1562, indo para Roma e depois para Lisboa, aonde chegou em 1569. Dois anos depois embarcaria para a Índia, morrendo em um naufrágio (Beccari, 1903-1917; Bergström, 1935; Curto, 2008; Machado, 1736-1737; Rego, 1953; Wicki, 1960).

140 Segundo Viré (1986) com as observações de alguns viajantes do Islã sobre macacos ou "homens selvagens" passíveis de serem associadas com gibões e siamangs (Hylobatidae) ou mesmo com orangotangos (Pongidae). Com efeito, em sua "Maravilhas da Criação" ("Ajâ'ib al-makhlûqât") o médico e geógrafo persa Zakariyâ al-Qazwînî (ca. 1203-1283 AD), reproduz as observações de um viajante do século IX, o historiador e geógrafo persa Ibn al-Faqîh al-Hamadhânî, o qual atesta existir na ilha de "Râminî" (i.e., Sumatra) "seres humanos que andam nus e descalços, cuja linguagem é desconhecida. Moram no alto das árvores, possuem pelos no corpo que cobrem suas pudendas. São numerosos, comem frutas nas árvores e evitam a presença humana. Se um deles é levado para locais habitados pelos homens, não permanece ali e foge para a selva" (in Kruk, 1995) ${ }^{141}$.

A primeira notícia mais detalhada de um orangotango vinda de um europeu pertenceria Jacob de Bondt mais conhecido entre nós como Jacobus Bontius - que viajou para a Ásia em 1627 como cirurgião a soldo da Companhia Privilegiada as Índias Orientais e terminou descrevendo o "orang-outang ou homem silvestre" em sua "Historiae Naturalis \& Medicae Indiae Orientalis"142.

141 Certos autores aventam a possibilidade dos antropóides asiáticos terem sido conhecidos pelos europeus desde a Antiguidade, enquanto outros lembram o vago comentário de Marco Polo (in Yule, 1903) sobre "grandes macacos de tal compleição que tinham a aparência de homens", referência por vezes atribuída a um gibão (Hylobatidae) ou mesmo a um orangotango (Pongidae). Para uma discussão sobre 0 assunto, vide Janson (1952); Jennison (1937); Huxley (1896); Lach (1970); McDermott (1938); Montagu (1941); Rijksen \& Meijaard (1999); Spencer (1995) e Wendt (1956).

1420 texto de Bontius acabaria sendo impresso postumamente como parte da "De Indiae Utriusque re naturali et medica" de Willem Pies - ou Guilherme Piso - cujo nome dispensa apresentações (Piso, 1658). 
Tomando como referência o"sátiro" de Plínio, “o Velho"143, o médico holandês assevera ter visto machos e fêmeas desses "sátiros" andando eretos, destacando em particular uma fêmea "que, por modéstia, se escondeu de estranhos e escondeu o rosto nas mãos (pois é necessário usar a palavra mãos) e chorou copiosamente, suspirando o tempo todo. Ela também realizou outras ações de um ser humano, de modo que nada de humano faltou, exceto a fala. De fato, os javaneses dizem que podem falar, mas não o faz por medo de serem obrigados a trabalhar [...] O nome que dão a essas criaturas é Ourang Outang, que significa homem da floresta. E estes, eles insistem, nascem dos amores das mulheres nativas que, com a lascívia detestável, se misturam com macacos"144. O texto é acompanhado pela gravura de uma fêmea ereta de aspecto nitidamente humanóide baseada, segundo autores como Spencer (1995), em uma prancha das "Peregrinationes in Terram Sanctam" de Bernhard von Breydenbach (1486) ou na cópia presente no primeiro volume da "Historia Animalium" de Conrad Gesner (1551). As semelhanças, contudo, são muito vagas e tal relação revela-se bastante discutível, ao contrário do observado em reproduções do original de Bontius publicadas mais tarde (e.g., Schotti, 1662) (Figuras 5 e 6). Existe muita controvérsia se a descrição Jacob de Bondt deve ser realmente atribuída a um orangotango e o mesmo se aplica ao estudo trazido à luz por Nicolaas Tulp - ou Tulpius - outro médico holandês que dissecou um primata proveniente da "ménagerie" do príncipe Frederik Hendrik van Oranje (Tulpius, 1641), o qual é identificado amiúde como um chimpanzé, Pan sp. ${ }^{145}$ No final do século XVII, o médico inglês Edward Tyson produziria a mais detalhada anatomia de um antropóide impressa até então (Tyson, 1699). Baseada indubitavelmente em um chimpanzé, essa publicação demonstraria que os ditos "homens silvestres" na realidade eram macacos (Figuras 7 e 8$)^{146}$.

Tanto a localidade geográfica ("Mar Roxo") quanto o porte ("tamanhos como mulas") do primata mencionado pelo jesuíta Fulgêncio Freire evocam um gorila, algo surpreendente se considerarmos que espécies desse gênero não foram assinaladas para a região, tendo sua ocorrência mais próxima representada pelas populações remanescentes de Gorilla beringei encontradas no oeste do Congo, noroeste de Ruanda e sudoeste de Uganda.

143 Na edição consultada da "Historia Naturalis" (Plínio, 1979-1984), as referências aos "sátiros" pertencem ao livro VIII, capítulo 80 e livro 10, capítulo 92. Existem grande divergência acerca desse animal, que já foi atribuído a espécies tão diversas como cercopitecos, babuínos, gibões, chimpanzés e orangotangos (vide Kitchell Jr., 2014).

144 "Plinius, ille Naturae Genius, lib. 7, cap. 2, de Satyris dixit: Sunt \& Satyri, subsolanis in Indiis locis \& montibus pernicissimum animal; tum quadrupedes, tum \& recte currentes humana specie \& effigie, propter velocitatem non nisi senes aut aegri capiuntur. Ast quod majorem meretur admirationem, vidi ego aliquot utriusque sexus erecte incedentes, imprimis cam (cujus effigiem hic exhibeo) Satyram foemellam tanta, verecundia ab ignotis sibi hominibus occulentem, tum quoque faciem manibus (liceat ita dicere) tegentem, ubertimque lacrymantem, gemitus cientem, \& caeteros humanus actus exprimentem, ut nihil eu humani de esse diceres praeter loquelam. Loqui vero eos casque posse, lavani aiunt, sed non velle, ne ad labores cogerentur: riducule me hercules. Nomen eu indunt Ourang Outang, quod hominen silvae significat, eosque nasci affirmant è libidine mulierum Indarum, quae Simiis \& Cercopithecis detestanda libidine miscent. Nec pueri credunt, nisi qui nondum aere lavantur" no original (vide Bontius in Piso, 1658).

145 Para maiores detalhes acerca dessa discussão, vide Dobson (1953); Forth (2008); Groves (2011); Reynolds (1967); Rijksen (1982); Rijksen \& Meijaard (1999) e Stiles \& Orleman (1927).

146 Para maiores detalhes acerca, vide Papavero, Pujol-Luz \& Llorente-Bousquets (2001).
Ademais, os informes sobre os grandes antropóides africanos parecem estar ausentes das fontes árabes trabaIhadas até o momento ${ }^{147}$ e os relatos europeus mostram-se bastante tardios, pois a literatura contemporânea costuma atribuir ao aventureiro inglês Andrew Battell a primeira observação de um mamífero desse tipo, no caso Gorilla gorilla (Savage, 1847) da África Oriental, entre os anos de 1590 e $1610^{148}$. Vizinho do clérigo e historiador Samuel Purchas, Battell teria suas aventuras publicadas, durante o ano de 1625, no segundo volume do célebre "Hakluytus Posthumus or Purchas his Pilgrimes" sob o título de "The strange adventures of Andrew Battell of Leigh in Angola and the adjoining regions". De acordo com esse relato, a região de Mayumba, costa do Gabão, seria habitada por "dois tipos de monstros", ambos "comuns em suas florestas". O maior deles, "chamado 'pongo', é em todas as proporções igual a um homem, porém é de estatura mais gigantesca do que um homem. Ele é, portanto, muito alto e tem feições humanas, olhos encovados, com longos pelos nas sobrancelhas. Sua face e orelhas não possuem pelos, assim como suas mãos. Seu corpo é todo coberto de pelos, mas não muito grossos, de cor escura. Não difere do homem exceto nas pernas, pois não possui panturrilha"149.

O texto de Battell guarda pouca semelhança com a vaga menção aos "sátiros" de Serra Leoa - "homens selvagens [...] todos cobertos de um cabelo ou sedas tão ásperas como de porco" - feita em 1506 no "Esmeraldo de situ orbis" de Duarte Pacheco Perreira ${ }^{150}$, aproximando-se mais

147 Vide Kruk (1995). A exemplo do observado em relação às formas asiáticas, existe grande controvérsia sobre a possibilidade de os antropóides africanos terem sido conhecidos na Antiguidade. 0 caso mais notório é o do navegador cartaginês Hannon, que supostamente teria chegado ao golfo da Guiné durante o século VI a.C., tendo encontrado "homens selvagens" - gorilas ou chimpanzés - cujas peles foram levadas para Cartago. A narrativa desse episódio seria traduzida por Schoff (1913) nos seguintes termos: "In the recess of this bay there was an island., like the former one, having a lake, in which there was another island, full of savage men. There were women, too, in even greater number. They had hairy bodies, and the interpreters called them Gorillae [Гopi $\lambda \lambda a c]$. When we pursued them we were unable to take any of the men; for they all escaped, by climbing the steep places and defending themselves with stones; but we took three of the women, who bit and scratched their leaders, and would not follow us. So we killed them and flayed them, and brought their skins to Cartage. For we did not voyage further, provisions failing us". Para maiores detalhes, vide Janson (1952); Jennison (1937); McDermott (1938); Montagu (1941); Morris \& Morris (1966); Spencer (1995); Toynbee (1973) e Wendt (1956).

148 Vide Gott \& Weir (2013); Groves (2011); Newman (2013); Papavero, Pujol-Luz \& LlorenteBousquets (2001); Schallei (2010) e Wendt (1956). Grande parte do que se conhece sobre Andrew Battell baseia-se em seus papéis pessoais e comentários esparsos recolhidos e publicados por seu vizinho Samuel Purchas $(1614,1625)$. Segundo consta, Battell teria nascido em Leigh, Essex, em torno de 1565, ingressando na guilda de pilotos local. Em 7 de maio de 1589, sob o comando de Abraham Cocke, deixou o porto de Plymouth para apresar navios espanhóis e portugueses no rio da Prata e litoral brasileiro. A expedição foi mal sucedida e os corsários terminaram por chegar ao Rio de Janeiro acossados pela fome e ventos contrários. Capturado por indígenas junto com cinco comparsas, Battell foi entregue às autoridades e tratado como prisioneiro de guerra, sendo enviado para Angola. Teria chegado em Luanda em junho de 1590 e permaneceu por duas décadas na África, participando inclusive das viagens de comércio realizadas pelos portugueses ao longo da costa. Voltaria para Leigh por volta de 1610 e ainda estava vivo em 1614 (Ravenstein, 1901).

149 "This Pongo is in all proportions like a man, but that he is more like a giant in stature than a man; for he is very tall, and hath a man's face, hollow-eyed, with long hair upon his brows. His face and ears are without hair, and his hands also. His body is full of hair, but not very thick, and it is of a dunnish colour. He differeth not from a man but in his legs, for they have no calf" no original (in Purchas, 1625). A descrição de Battell também foi objeto de várias disputas, havendo aqueles que se recusaram a atribuí-la a um gorila (e.g., Burton, 1876; Du Chaillu, 1861; Janson, 1952).

150 "Também ha quy homens saluajes a que os antiguos chamaram satiros \& som todos cubertos de hum cabello ou sedas quasy tam asperas como de porco \& estes paresem creatura humana \& husam ho coyto com suas mulheres como nos usamos com as nossas, \& em uez 


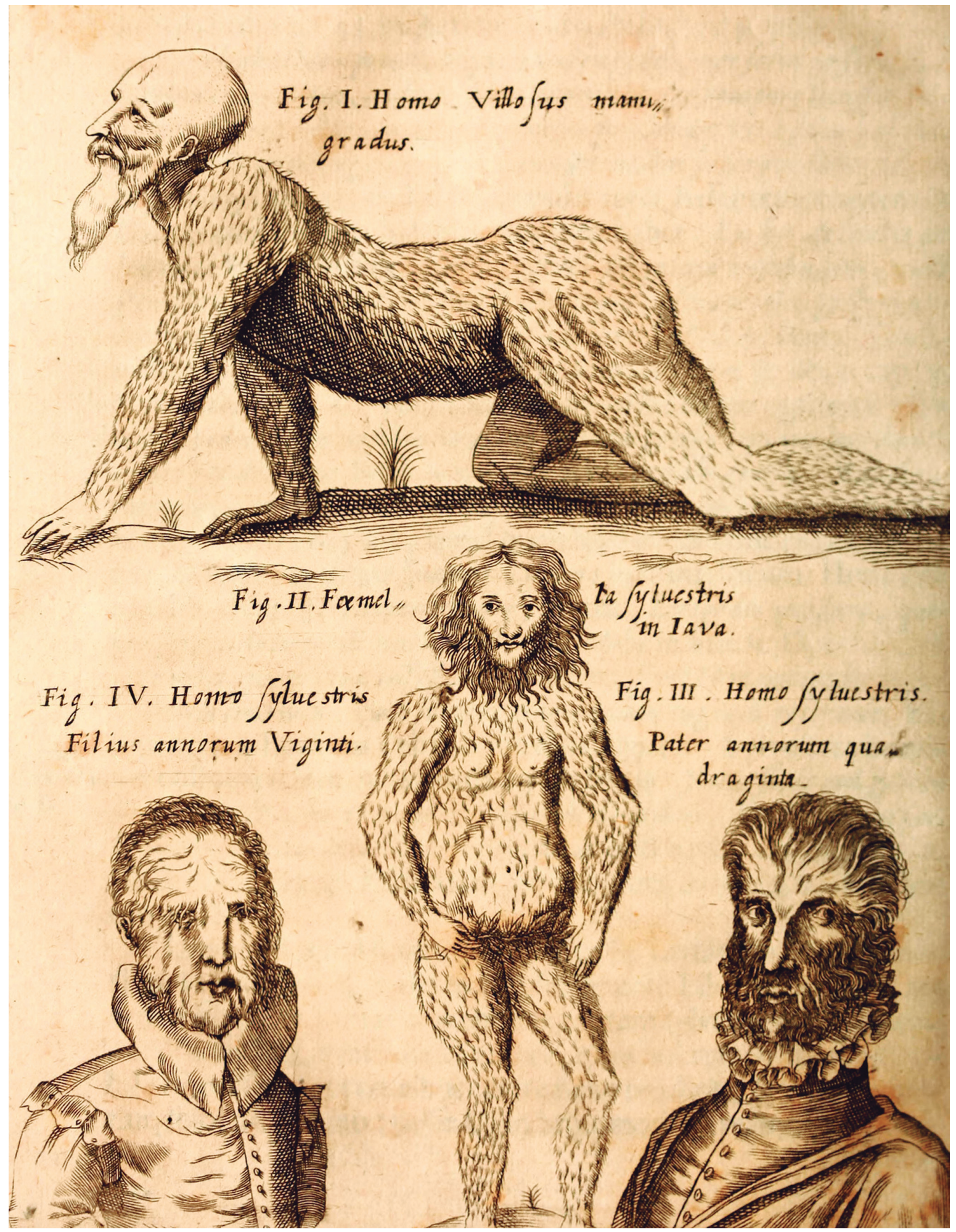

Figura 6. A "foemella sylvestris in Java" da "Physica Curiosa" de Gasparis Schotti (1662).

do relato feito por André Álvares de Almada no "Tratado breve dos rios da Guiné do Cabo Verde", manuscrito datado de 1594. Segundo esse último, haveria na região "uma casta de monos, chamados 'daris', sem rabos e se não tivessem cabelos podia-se dizer que eram humanos como nós, porque nas feições há pouca diferença. Andam em pé [...]

de falarem gritam quando lhe fasem mal \& por que estes andam na maior espesura desta serra poucas vezes os podem thomar se nom em sendo mossos pequenos, muitas outras cousas se poderiom dizer delles que por nom fazer longuo sermon leixo de escreuer" no original (in Pereira, 1892). são baixos de corpo, grossos, de boas pernas e braços"151. $\mathrm{Na}$ opinião de alguns, ambas passagens deveriam ser

151 "Nella ha huaa casta de monos que não ha em outro Guiné, chamados 'Daris', sem rabos e se não tivessem cabellos podia-se dizer que erào humanos, como nos; porque nas feições ha pouca differença. Andão em pé, e alguns que se tomào depois de se fazerem á casa vão catar agoa ao rio em huma vasilha, e a trazem na cabeç; mas tem tal qualidade que em chegando á porta da pousada lhe hão de acodir de pressa e tomar-lhe a vasilha da cabeça; e não fazendo isto elles mesmos as deixão cahir no chão, e se põem a chorar com grandes gritos. Malhão nos pilões dos negros os mantimentos como huma pessoa. São baixos de corpo, grossos, de boas pernas e braços. São amigos da conversação das moças, e se achão algumas desencaminhadas e sós, as apanhão, e levão comsigo, e lhes fazem muito mimo ao seu modo" no original (Almada, 1841). 


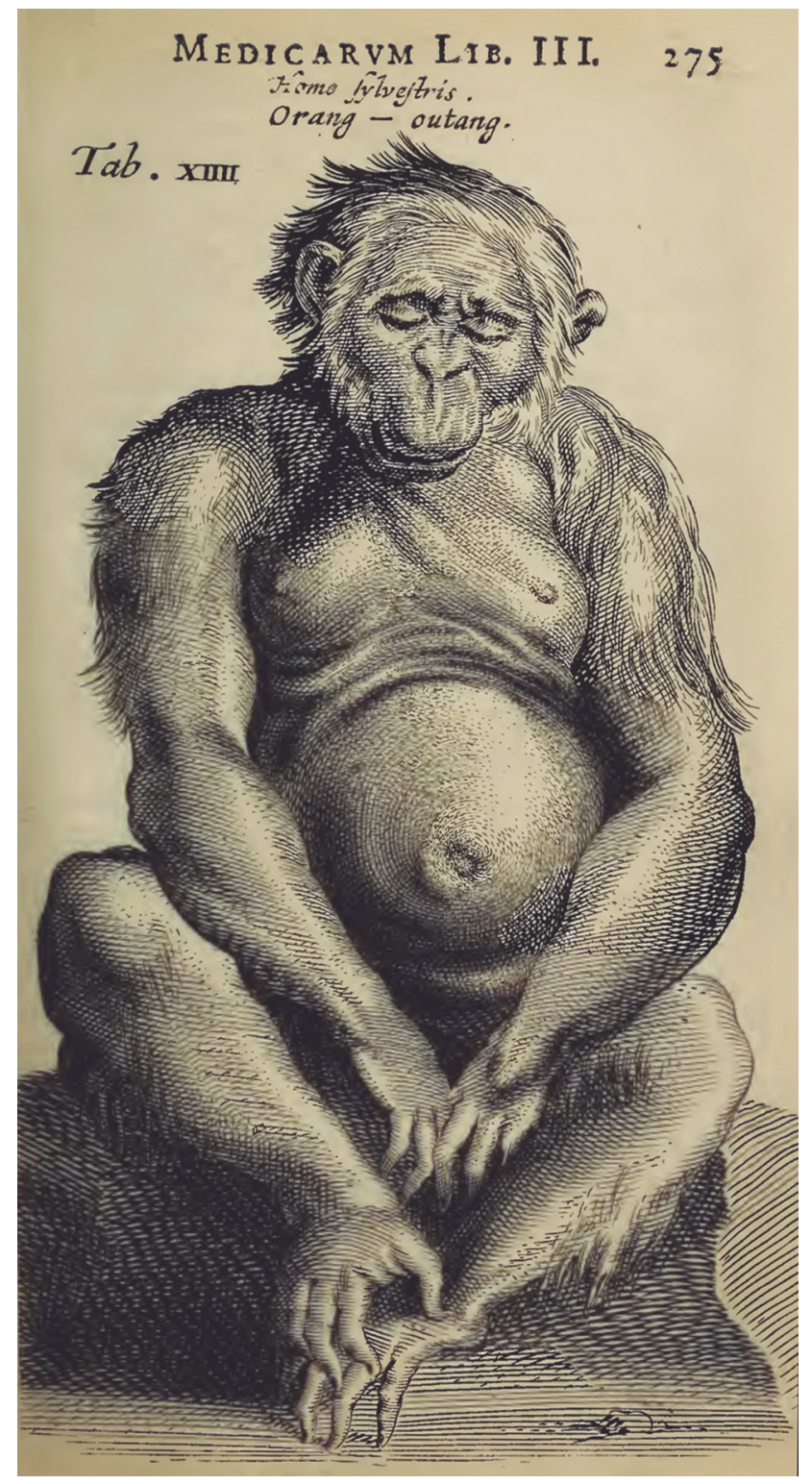

Figura 7.0 "homo sylvestris" ou "ourang-outang" da "Observationum medicarum" de Nicolaas Tulpius (1641).

atribuídas aos chimpanzés, Pan troglodytes (Blumenbach, 1776), hipótese que provavelmente transformaria a observação de Duarte Pereira na primeira referência feita por um europeu a um antropóide africano ${ }^{152}$.

A notícia de um primata "tamanho como mulas" visto no "mar Roxo" não encontra paralelo nos escritos de outros viajantes que percorreram a região nesse mesmo período, pois autores como Manoel de Almeida, Francisco Álvares e Pero Pais ${ }^{153}$ tratam apenas de diferentes representantes dos Cercopithecidae. Tampouco há informação sobre gorilas, chimpanzés e orangotangos terem sido oferecidos como presente a potentados ou participado do intenso tráfico de animais promovido desde tempos imemoriais, ao contrário do observado com numerosos outros primatas da África e Ásia. Nesse contexto, o tes-

152 Vide R.E. de Azevedo Basto in Pereira (1892) e Ferronha et al. (1993).

153 Vide a "Verdadera informação das terras do Preste Joaõ" de Francisco Álvares (1540), a "História da Etiópia" de Pero Pais (1945) e a "História de Ethiopia a alta" de Manoel de Almeida, tanto o manuscrito original (in Beccari 1903-1917), quanto a versão compilada pelo padre Baltazar Teles (vide M. de Almeida, 1660).

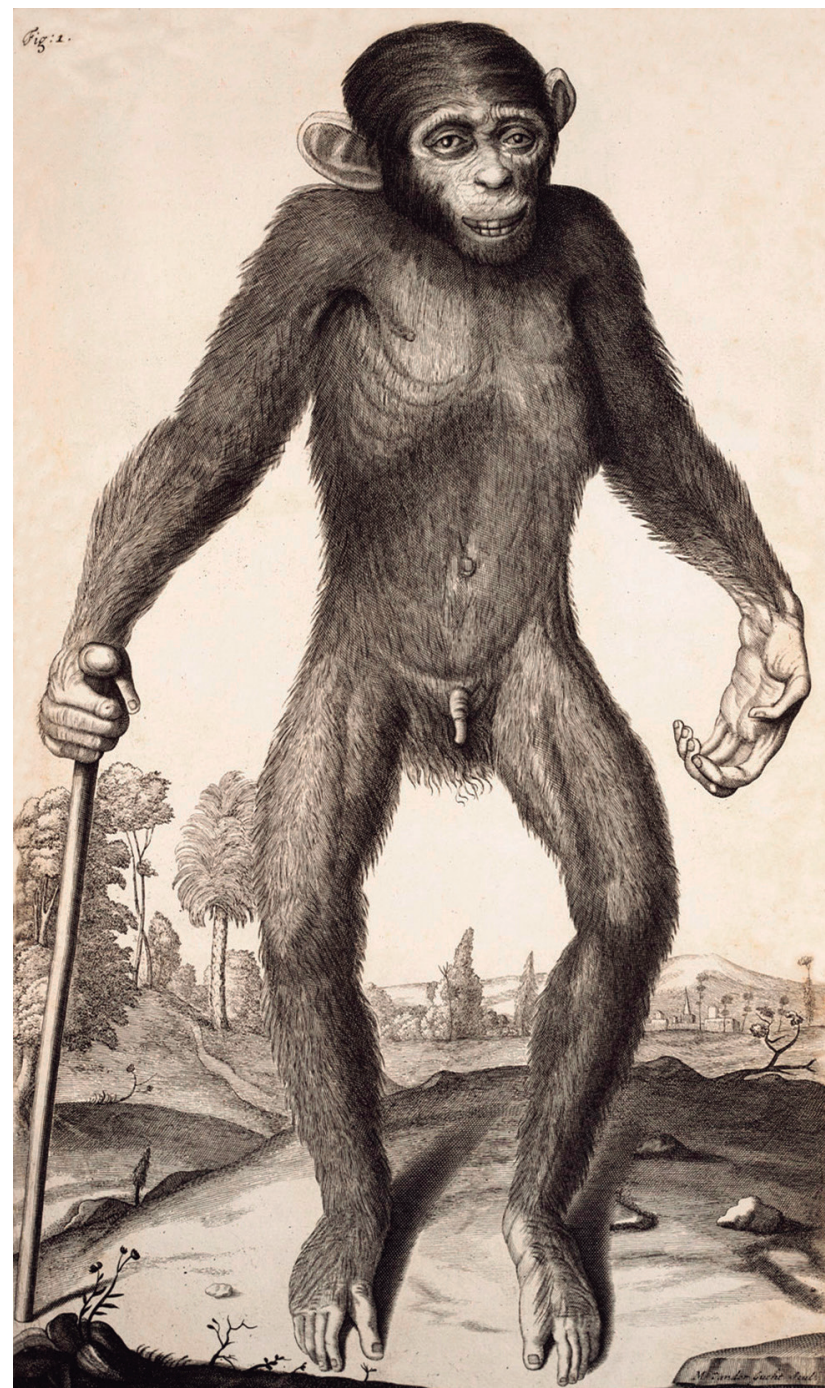

Figura 8. 0 "orang-outan sive homo sylvestris" da "Anatomy of a pygmie" de Edward Tyson (1699).

temunho do padre Fulgêncio Freire é particularmente digno de nota, pois corresponderia a um registro levado a cabo entre 1555 e 1569, portanto antecedendo as observações de Andrew Battell (1590-1610) e André Álvares de Almada (1594), podendo eventualmente constituir a segunda citação aos antropóides africanos feita por um europeu e a primeira referência conhecida a um gorila, algo a ser confirmado no futuro pela leitura do vasto acervo documental daqueles que ousaram percorrer a África Oriental durante os séculos XVI e XVII.

\section{AGRADECIMENTOS}

Cumpre agradecer a João Alves de Oliveira (Departamento de Vertebrados, Museu Nacional, Universidade Federal do Rio de Janeiro) e Leila Maria Pessôa (Departamento de Zoologia, Instituto de Biologia, Universidade Federal do Rio de Janeiro) pelos comentários apresentados. Vale destacar ainda o apoio concedido pelo Conselho Nacional de Desenvolvimento Científico e Tecnológico (CNPq) às pesquisas realizadas por Nelson Papavero durante os últimos anos. 


\section{REFERÊNCIAS}

Agostinho de Santa Maria. 1722. Santuario Mariano, e historia das imagens milagrosas de Nossa Senhora. Lisboa, Officina de Antonio Pedrozo Galram. v. 9.

Albuquerque, L.M. 1969. 0 Livro de Marinharia de Manuel Álvares. Lisboa, Junta de Investigação do Ultramar.

Albuquerque, L.M. 1978. Escalas da carreira da Índia. Revista da Universidade de Coimbra, Coimbra, 26: 137-144.

Albuquerque, L.M. 1994. Carreira da Índia. In: Albuquerque, L.M. (Org.). Dicionário de História dos Descobrimentos Portugueses. [Lisboa], Editora Caminho. v. 1, p. 204-209.

Almaça, C. 1993. The beginning of Portuguese carcinology. In: Truesdale, F., History of Carconology. Rotterdam, A.A. Balkema. p. 31-39.

Almaça, C. 2002. A zoologia pré-lineana no Brasil. Lisboa, Museu Bocage.

Almada, A.A. de 1841. Tratado breve dos rios da Guiné do Cabo Verde desde o rio do Sanagá até os baixos de Sant'Anna. Porto, Typographia Commercial Portuense.

Almeida, L. de 1598. Carta do irmão Luis Dalmeida, pera os irmãos da Companhia de IESV, da ilha de Xiquy, a vinte de Outubro, de 1566. In: Cartas qve os padres e irmãos da companhia de lesus escreuerão dos reynos do lapão \& China aos da mesma companhia da India, \& Europa, desdo anno de 1549 atè 0 de 1580. Euora, Manoel de Lyra. p. $213 v-224 v$.

Almeida, M. de 1660. Historia de Ethiopia a alta tirada da que mais largamente compôs na India o Pe Manoel de Almeida pelo Pe. Balthazar Tellez. Coimbra, Manoel Dias.

Alves, M. 1976. Dicionário de artistas e artífices na Bahia. Salvador, Universidade Federal da Bahia.

Amado, M.T. 1994. Goa. In: Albuquerque, L.M. (Org.). Dicionário de história dos descobrimentos Portugueses. [Lisboa], Editora Caminho. v. 1, 463p.

Amorim, M.A. 2005. Os franciscanos no Maranhão e Grão-Pará: Missão e cultura na primeira metade de seiscentos. Lisboa, Universidade de Lisboa \& Universidade Católica Portuguesa.

Anchieta, J. de 1933. Cartas, informações, fragmentos históricos e Sermões do Padre Joseph de Anchieta, S.J. (1554-1594). Rio de Janeiro, Civilização Brasileira.

Andrade e Silva, J.B. de 1790. Memoria sobre a Pesca das Baleas e Extração de seu Azeite; com algumas reflexões a respeito das nossas Pescarias. Memorias Economicas da Real Academia das Sciencias de Lisboa, para 0 adiantemento da Agricultura, das Artes, e da Industria em Portugal e suas conquistas, Lisboa, 2: 388-412.

Aristóteles. 1907. De Anima. Cambridge, Cambridge University Press.

Backer, A. \& Backer, A. 1886. Bibliothèque des écrivains de la Compagnie de Jésus ou notices bibliographiques de tous les ouvrages publiés par les membres de la Compagnie de Jésus depuis la fondation de l'ordre jusqu'a nos jours; des apologies, des controverses religieuses, des critiques littéraires et scientifiques suscitées a leur sujet. Liége, Imprimerie de L. Grandmont-Donders.

Barata, J. da G.P. 1968. 0 navio "São Gabriel" e as naus manuelinas. Revista da Universidade de Coimbra, Coimbra, 24: 443-474.

Barata, J. da G.P. 1970. 0 traçado das naus e galeões portugueses de 1550-80 a 1640. Coimbra, Junta de Investigações do Ultramar.

Barata, J. da G.P.; Moura, C.F. \& Guedes, M.J. 1975. A navegação a vela no litoral brasileiro. In: Guedes, M.J. (Org.). História Naval Brasileira. Rio de Janeiro, Ministério da Marinha. v. 1, Tomo 1, p. 53-137.

Beccari, C. (Ed.). 1903-1917. Rerum Aethiopicarum Scriptores Occidentales inediti a saeculo XVI ad XIX. Romae, C. de Luigi.

Bergström, M. (Ed.). [1935]. Abissínia. In: Grande Enciclopédia Portuguesa e Brasileira. Lisboa, Editorial Enciclopédia. v. 1, p. 74-77.
Bolzani, G.P.V. 1556. Hieroglyphica sive de Sacris Aegyptiorum literis commentarii. Basileae, [Michael Isengrin].

Boxer, C.R. (Ed.). 1959. The tragic history of the sea 1589 1622: narratives of the shipwreks of the portuguese East Indiamen São Thomé (1589), Santo Alberto (1593), São João Baptista (1622), and the journey of the survivors in South East Africa. Cambridge, Hakluyt Society.

Boxer, C.R. (Ed.). 1968. The tragic history of the sea 1559-1565: narratives of the shipwreks of the portuguese East Indiamen Aguia and Garça (1559), São Paulo (1561) and the misadventures of the Brazilian ship Santo Antonio (1565). Cambridge, Hakluyt Society.

Boxer, C.R. 1961. The Carreira da India: ships, men, cargoes, voyages. In: 0 centro de estudos históricos ultramarinos e as comemorações henriquinas. Lisboa, Centro de Estudos Históricos Ultramarinos, p. 33-82.

Boxer, C.R. 1969. The Portuguese Seaborne Empire 1415-1825. New York, Alfred A. Knopf.

Boxer, C.R. 1971. The principal ports of call in the Carreira da Índia. LuzoBrasilian Review, Madison, 8(1): 3-29.

Branco, E.J. \& Rodrigues, A.M.T. 1998. Levantamento das comunidades pesqueiras da Baía da Babitonga, SC. In: Rodrigues, A.M.T.; Branco, E.J; Pereira, M.T.; Zimm, C.E.; Ribeiro, G.C.; Branco, J.0.; Kuroshima, K.N.; Clezar, L.; Brutto, L.F.; Cremer, M.J., Souza Filho, M.A.C.; Hostim Silva, M.; Tognella, M.M.P; Alves, S \& Bellotto, V. Proteção e controle de ecossistemas costeiros: manguezal da Baía da Babitonga. Brasília, Instituto Brasileiro do Meio Ambiente e dos Recursos Naturais Renováveis. p. 85-102.

Breder, C.M. 1938. A contribution to the life histories of Atlantic Ocean flyingfishes. Bulletin of the Bingham Oceanography Collection, New Haven, 6(5): 1-126.

Breydenbach, B. von 1486. Peregrinationes in Terram Sanctam. Ciuitate Moguntina, Erhardũ Reũwich.

Brito, B.G. de 1735-1736. Historia Tragico-Maritima. Lisboa, Officina da Congregação do Oratorio.

Brito, B.G. de 1904. História Trágico-Marítima. Lisboa, Bibliotheca de Classicos Portuguezes.

Brito, B.G. de 1955. História Trágico-Marítima. Lisboa, Editorial Sul.

Brito, B.G. de 1971. História Trágico-Marítima. Lisboa, Edições Afrodite.

Brito, B.G. de 1998. História Trágico-Marítima. Rio de Janeiro, Lacerda Editores \& Contraponto Editora.

Brito, C.M.R. da S. 2009. Os mamíferos marinhos nas viagens marítimas pelo Atlântico entre os séculos XV e XVIII: a evolução da ciência e do conhecimento. Lisboa: Tese (Doutorado) - Pós-Graduação em História dos Descobrimentos e da Expansão Portuguesa, Faculdade de Ciências Sociais e Humanas, Universidade Nova de Lisboa.

Bruun, A.F. 1935. Flying-fishes (Exocoetidae) of the Atlantic. Dana Report, Copenhagen, 6: 1-106.

Burton, R.F. 1876. Two trips to gorilla land and the cataracts of the Congo. London, Sampson Low, Marston, Low and Searle.

Calmon, P. 1939. Historia do Brasil. As origens (1500-1600). São Paulo, Companhia Editora Nacional. v. 1.

Cardim, F. 1939. Tratados da Terra e da Gente do Brasil. São Paulo, Companhia Editora Nacional.

Cícero. 1927. The Tusculan Disputations. Cambridge, Mass., Harvard University Press.

Cícero. 1949. On Invention. The Best Kind Of Orator. Topics. Cambridge, Massachusetts, Harvard University Press.

Correia, A.M; Sérgio, A.; Gonçalves, A.A. et al. (Ed.) [ca. 1955]. Jacome de Vicariis. In: Grande enciclopédia portuguesa e brasileira. Lisboa, Editorial Enciclopédia. v. 35, Viana do Castelo - Vilar Seco, p. 81.

Costa, A.F. da (Ed.). 1940a. Livro de Marinharia de Bernardo Fernandes (cêrca de 1548). Lisboa, Agência Geral das Colónias. 
Costa, A.F. da (Ed.). 1940b. Roteiro da navegação e carreira da Índia, com seus caminhos \& derrotas, sinais, \& aguageis \& diferenças da agulha: tirado do que escreveu Vicente Rodrigues \& Diogo Afonso, pilotos antigos. / Agora novamente acrescentado a viagem de Goa por dentro de são Lourenço, \& Moçambique, \& outras muitas cousas, \& advertências, por Gaspar Ferreira Reimão, cavaleiro do hábito de Santiago, \& Piloto mór dêstes Reinos de Portugal. 2. ed.Lisboa, Agência Geral das Colónias.

Cunha, F.A.X. da 1993. Contributos da missionação para o avanço das ciências. In: Congresso Internacional de História Missionação Portuguesa e Encontro de Culturas, 1, 1992, Lisboa. Actas ... Braga, Universidade Católica Portuguesa, Comissão Nacional para as Comemorações dos Descobrimentos Portugueses \& Fundação Evangelização e Culturas., p. 39-40. v. 3 (Igreja, Sociedade e Missionação)

Curto, P.M. 2008. História dos Portugueses na Etiópia (1490-1640). Porto, Campo das Letras.

Daley, B.E. 2006. Gregory of Nazianzus. London, Routledge.

Dobson, J. 1953. John Hunter and the early knowledge of the Anthropoid apes. Proceedings of the Zoological Society of London, London, 123(1): 1-12.

Domingues, F.C. [2006]. Navios portugueses dos séculos XV e XVI. Vila do Conde, Museu de Vila do Conde.

Domingues, F.C. 1994a. Galeão. In: Albuquerque, L.M. (Org.). Dicionário de História dos Descobrimentos Portugueses. [Lisboa], Editora Caminho. v. 1, p. 443.

Domingues, F.C. 1994b. Nau. In: Albuquerque, L.M. (Org.). Dicionário de História dos Descobrimentos Portugueses. [Lisboa], Editora Caminho. v. 2, p. 792-794.

Domingues, F.C. 1994c. Tonel. In: Albuquerque, L.M. (Org.). Dicionário de História dos Descobrimentos Portugueses. [Lisboa], Editora Caminho. v. 2, p. 1039.

Domingues, F.C. \& Guerreiro, I. 1988. A vida a bordo na Carreira da Índia (século XVI). Revista da Universidade de Coimbra, Coimbra, 34: 185-225.

Dorea, L.E. 2006. Histórias de Salvador nos nomes das suas ruas. Salvador, Editora da Universidade Federal da Bahia.

Du Chaillu, P.B. 1861. Explorations \& adventures in equatorial Africa. London, John Murray.

Duffy, J. 1955. Shipwreck and Empire: being an account of Portuguese maritime disasters in a century of decline. Cambridge, Massachusetts, Harvard University Press.

Ferreira, A.R. 1972. Viagem Filosófica pelas capitanias do Grão Pará, Rio Negro, Mato Grosso e Cuiabá. Memórias Zoologia, Botânica. Rio de Janeiro, Conselho Federal de Cultura.

Ferronha, A.L.; Bettencourt, M. \& Loureiro, R. [1993]. A fauna exótica dos descobrimentos. [Lisboa], Edição Elo.

Fonseca, Q. da 1938. Diários da navegação da Carreira da Índia nos anos de 1595, 1596, 1597, 1600 e 1603. Lisboa, Academia das Ciências de Lisboa.

Forth, G. 2008. Images of the Wildman in Southeast Asia. London, Routledge.

Frade, G. 2007. A arquitetura sagrada no Brasil: sua evolução até as vésperas do Concílio Vaticano II. São Paulo, Edições Loyola.

França, C. 1926. Os portugueses do século XVI e a Historia Natural do Brasil. Revista de História, Lisboa, 15(57-60): 124-128.

Franco, A. 1719. Imagem da Virtude em o noviciado da Companhia de Jesus no Real Collegio de Jesus em Coimbra, na qual se contem as vidas, e virtudes de muytos religiozos, que nesta santa casa foraõ noviços. Coimbra, Real Collegio das Artes da Companhia de Jesus. v. 2.

Freitas, M.A. de \& Silva, T.F.S. 2005. Herpetofauna da Mata Atlântica nordestina. Pelotas, USEB.

Freitas, M.A. de \& Silva, T.F.S. 2007. A herpetofauna das caatingas e áreas de altitude do nordeste brasileiro. Pelotas, USEB.

Gesner, C. 1551. Historiae Animalium Lib. I. de Quadrupedibus uiuiparis. Tigvri, Christ. Froschevervm.
Gilroy, C.G. 1845. The History of silk, cotton, linen, wool, and other fibrous substances. New York, Harper \& Brothers.

Glacken, C.J. 1967. Traces on the Rhodian Shore: nature and culture in Western thought from ancient times to the end of eighteenth century. Berckley, University of California Press.

Godinho, V.M. 1963-1965. Os Descobrimentos e a economia mundial. Lisboa, Arcádia.

Gonçalves, S. 1962. Primeira parte da historia dos religiosos da Companhia de Jesus e do que fizeram com a divina graça na conversão dos infieis a nossa santa fee catholica nos reynos e provincias da India Oriental. Vol. 3, História da Companhia de Jesus no Oriente (1560-1570).Coimbra, Atlântida.

Gott, T. \& Weir, K. 2013. Gorilla. London, Reaktion Books.

Groves, C. 2011. Extended family: a personal look at the history of primatology. Alington, Conservation International.

Guerra, S. 2013. El gusano y la mariposa. Uma consideración históricoespiritual. Revista de Espiritualidad, Madrid, 72(289): 537-571.

Guinote, P.; Frutuoso, E. \& Lopes, A. 1998. Naufrágios e outras perdas da Carreira da Índia: séculos XVI e XVII. Lisboa, Grupo de Trabalho do Ministério da Educação para as Comemorações dos Descobrimentos.

Guyon, M.Y.L.G. 1865. Histoire naturelle et médicale de la chigue (Rynchoprion penetrans 0 ken), insecte parasite des régions tropicales des deux Amériques. Revue et magasin de zoologie pure et appliquée, ze série, Paris, 17: 295-307.

Guyon, M.Y.L.G. 1866. Histoire naturelle et médicale de la chigue (Rynchoprion penetrans 0 ken). Revue et magasin de zoologie pure et appliquée, ze série, Paris, 18: 64-70; 111-117; 326-328; 359-363; 445-461.

Guyon, M.Y.L.G. 1867. Histoire naturelle et médicale de la chigue (Rynchoprion penetrans $0 \mathrm{ken})$. Revue et magasin de zoologie pure et appliquée, ze série, Paris, 19: 7-15, 208-211, 276-290, 324-327.

Guyon, M.Y.L.G. 1868. Histoire naturelle et médicale de la chigue (Rynchoprion penetrans $0 \mathrm{ken})$. Revue et magasin de zoologie pure et appliquée, 2 ¿érie, Paris, 20: 25-35; 70-84; 101-107; 171-182; 245-251; 301-308; 433-435.

Guyon, M.Y.L.G. 1869. Histoire naturelle et médicale de la chigue (Rynchoprion penetrans $0 \mathrm{ken})$. Revue et magasin de zoologie pure et appliquée, 2 série, Paris, 21:70-75;212-218;284-292; 325-331; 384-390; 413-418; 425-434.

Hanes, L. 1923. The career of the Earl of Essex from the Islands Voyage in 1597 to his execution in 1610. Philadelphia, University of Pennsylvania.

Hetzel, B. \& Lodi, L. 1993. Baleias, botos e golfinhos: guia de identificação para o Brasil. Rio de Janeiro, Nova Fronteira.

Huxley, T.H. 1896. Man's place in nature and other anthropological essays. New York, D. Appleton.

Jaboatão, A. de Santa Maria 1858-1862. Novo orbe serafico brasilico, ou, chronica dos frades menores da provincia do Brasil. Rio de Janeiro, Typ. Brasiliense de Maximiniano Gomes Ribeiro.

Janson, H.W. 1952. Apes and Ape Lore in the Middle Ages and the Renaissance. London, University of London.

Jennison, G. 1937. Animals for show and pleasure in Ancient Rome. Manchester, Manchester University Press.

Junqueiro, M.C. 1994. Afonso de Albuquerque. In: Albuquerque, L.M. (Org.). Dicionário de História dos Descobrimentos Portugueses. [Lisboa], Editora Caminho. v. 1, p. 34-39.

Kircher, A. 1646. Ars Magna Lvcis et Vmbrae. Romae, Typographia Ludouici Grignani.

Kist, L. 2008. Os jesuítas no começo do Brasil, guiados pela fé e regidos pela colônia. São Leopoldo: Dissertação (Mestrado): Pós-Graduação em História. Universidade do Vale do Rio dos Sinos.

Kitchell Jr., K.F. 2014. Animals in the Ancient World from A to Z. London, Routledge.

Kitchell Jr., K.F. \& Resnick, I.M. (Org.). 1999. Albertus Magnus On Animals: a medieval summa zoologica. Baltimore, Johns Hopkins University Press. 
Kockel, M.F. 2014. Naufrágios e outros infortúnios na História Trágico-Marítima da Carreira da Índia (séculos XVI e XVII). Franca: Tese (Mestrado) - PósGraduação em História, Faculdade de Ciências Humanas e Sociais, Universidade Estadual Paulista "Júlio de Mesquita Filho".

Kruk, R. 1995. Tradicional Islamic views of apes and monkeys. In: Corbey, R. \& Theunissen, B. (Ed.). Ape, man, apeman: changing views since 1600. Leiden, Leiden University. p. 29-41.

L'Écluse, C. de 1605. Exoticorum Libri Decem: Quibus Animalium, Plantarum, Aromatum, aliorumque peregrinorum Fructuum historiae describuntur. Antuerpiae, Ex Officina Plantiniana Raphelengii.

Lacerda, T. 2006. Os capitães das Armadas da Índia no reinado de D. Manuel I uma análise social. Lisboa, Tese (Mestrado) - Pós-Graduação em História dos Descobrimentos e da Expansão Portuguesa, Faculdade de Ciências Sociais e Humanas, Universidade Nova de Lisboa.

Lach, D.E. 1970. Asia in the making of Europe. Chicago, University of Chicago Press. 2v.

Lanciani, G. 1979. Os relatos de naufrágios na literatura portuguesa dos séculos XVI X XVII. Lisboa, Secretaria de Estado da Cultura.

Lanciani, G. 1984. Naufragi e peregrinazioni americane di Gaspar Afonso. Milano, Istituto Editoriale Cisalpino-Goliardica.

Lanciani, G. 1997. Sucessos e naufrágios das naus portuguesas. Lisboa, Editora Caminho.

Lanciani, G. 2006. Morfologie del viaggio: l'avventura maritime portoghese. Milano, Edizioni Universitarie di Lettere Economia Diritto.

Lapa, J.R. do A. 1968. A Bahia e a Carreira da Índia. São Paulo, Companhia Editora Nacional.

Laval, F.P. de 1858. Viagem de Francisco Pyrard, de Laval, contendo a noticia de sua navegação ás Indias Orientaes, ilhas de Maldiva, Maluco, e ao Brazil, $e$ os differentes casos, que Ihe aconteceram na mesma viagem nos dez annos que andou nestes paizes: (1601 a 1611) com a descripção exacta dos costumes, leis, usos, policia, e governo: do trato e commercio, que nelles ha: dos animaes, arvores, fructas, e outras singularidades, que alli se encontram. Nova Goa, Imprensa Nacional.

Leão, D.N. do 1610. Descripção do Reino de Portvgal. Lisboa, lorge Rodriguez.

Leitão, H.J. dos S. \& Lopes, J.V. 1974. Dicionário da linguagem de marinha antiga e actual. Lisboa, Centro de Estudos Históricos Ultramarinos.

Leite, S.S. 1938a. História da Companhia de Jesus no Brasil. Vol. 1: século XVI - 0 estabelecimento. Lisboa \& Rio de Janeiro, Livraria Portugália \& Civilização Brasileira.

Leite, S.S. 1938b. História da Companhia de Jesus no Brasil. Vol. 2: século XVI a obra. Lisboa \& Rio de Janeiro, Livraria Portugália \& Civilização Brasileira.

Leite, S.S. 1953. Artes e oficios dos jesuítas no Brasil (1549-1760). Lisboa \& Rio de Janeiro,Edições Brotéria \& Livros de Portugal.

Leite, S.S. 1955. Cartas do Brasil e mais escritos do P. Manuel da Nóbrega. Universidade de Coimbra, Coimbra.

Leite, S.S. 1965. Novas páginas de História do Brasil. São Paulo, Companhia Editora Nacional.

Léry, J. de 1578. Histoire d'vn voyage fait en la terre dv Bresil, avtrement dite Amerique. La Rochelle, Antoine Chuppin.

Linschoten, J.H. van 1596. Itinerario, Voyage ofte Schipvaert Jan Huygen van Linschoten naer Oost ofte Portugaels Indien inhoudende een corte beschryvinghe der selver Landen ende zee-custen met aenwysinge van alle de voornaemde principale Havens Revieren hoecken ende plaetsen tot noch toe vande Portugesen ontdeckt ende bekent. Amstelredam, Cornelis Claesz.

Lopes, F. 1868. Santo Antonio de Lisboa, nascimento, creação, vida, morte e milagres d'este bemaventurado santo. Porto, Typographia do Commercio do Porto.

Machado, D.B. 1736-1737. Memorias para a historia de Portugal, que comprehendem o governo del Rey D. Sebastiaõ, único em o nome, e decimo sexto entre os Monarchas Portuguezes: Do anno de 1561. Até o anno de 1567. Lisboa, Officina de Joseph Antonio da Sylva.

Madeira, M.A. 1999. Notícias sobre a história trágico-marítima. Lugar Comum, Rio de Janeiro, 7 (janeiro-abril): 93-102.

Madeira, M.A. 2005a. Livro dos naufrágios: ensaio sobre a história trágicomarítima. Brasília, Editora da Universidade de Brasília.

Madeira, M.A. 2005b. Viagem e sucesso da nau São Francisco. In: Congresso da Associação Brasileira de Literatura Comparada, 30, 1962, Niterói. Limites - Anais ... São Paulo, Editora da Universidade de São Paulo. p. 103-108.

Marchant, A. 1941. Colonial Brazil as a way station for the Portuguese India Fleets. Geographical Review, New York, 31(3): 454-465.

Marešová, J. 2013. Álvar Núñez Cabeza de Vaca y Gaspar Afonso: escrituras de dos peregrinos por el Nuevo Mundo. In: Bernal, C.R. (Ed.). Diálogos culturales em la literatura Iberoamericana. Madrid, Editorial Verbum, p. 161-172.

Marques, J.F. 1996. Frei Cristóvão de Lisboa, missionário no Maranhão e Grão Pará (1624-1635), e a defesa dos índios brasileiros. Revista da Faculdade de Letras - História, Porto, 13: 323-351.

Matos, A.T. de 1988. As escalas do Atlântico no século XVI. Revista da Universidade de Coimbra, Coimbra, 34: 157-183.

McDermott, W.C. 1938. The Ape in Antiquity. Baltimore, Johns Hopkins Press.

Mello-Leitão, C. de 1941. Historia das expedições cientificas no Brasil. São Paulo, Companhia Editora Nacional.

Mello-Leitão, C. de 1946. Os jesuítas e a biologia no Brasil. In: Anais do IV Centenário da Companhia de Jesus. Rio de Janeiro, Serviço de Documentação, p. 121-132.

Mello-Leitão, C. de 1951. Os jesuítas e a biologia no Brasil. Chronica Botanica, Waltham, 12(4/6): 205-211.

Mendonça, M.C. de 1972. Raízes da formação admnistrativa do Brasil. Rio de Janeiro, Instituto Histórico e Geográfico Brasileiro \& Conselho Federal de Cultura.

Mermier, G.R. (Org.). 1992. A medieval book of beasts: Pierre de Beauvais' bestiary. Lewiston, Edwin Mellen Press.

Miranda, E.E. de 2004. 0 descobrimento da biodiversidade: a ecologia de índios, jesuítas e leigos no século XVI. São Paulo, Edições Loyola.

Moniz, A.M. de A. 2001. A História Trágico-Marítima: identidade e condição humana. Lisboa, Colibris.

Moniz, A.M. de A. 2009. Três representações quinhentistas da utopia na literatura portuguesa. In: Silva, M. de F. (Org.). Utopias e distopias. Coimbra, Imprensa da Universidade de Coimbra. p. 195-207.

Montagu, M.F.A. 1941. Knowledge of the Ancients regarding the ape. Bulletin of the History of Medicine, Baltimore, 10: 525-543.

Monteiro, J.R.V. 1974. A viagem de regresso da Índia da nau "São Pantaleão" no ano de 1596. Revista da Universidade de Coimbra, Coimbra, 25: 8-185.

Morais, J.C. 1941. 0 conhecimento dos ventos do Atlântico e do Índico nos séculos XV e XVI. Memórias e Notícias, Coimbra, 10: 1-47.

Morris, R. \& Morris, D. 1966. Men and apes. New York, McGraw-Hill.

Murphy, J.C. \& Henderson, R.W. 1997. Tales of Giant Snakes: A Historical Natural History of Anacondas and Pythons. Malabar, Fl., Krieger Publishing Company.

Newman, J.L. 2013. Encountering gorillas. A chronicle of discovery, exploitation, understanding and survival. Lanham, Rowman \& Littlefield Publishers.

Nomura, H. 1996. História da Zoologia no Brasil: Século XVI (Segunda Parte). Coleção Mossoroense (Série C), Mossoró, 904: 90-193.

Orta, G. d.' 1891-1895. Coloquios dos simples e drogas da India. Lisboa, Academia Real das Sciencias de Lisboa.

Ortelius, A. 1570. Theatrum Orbis Terrarum. Antverpiae, Egidius Coppens.

Ovídio. 1916. Metamorphoses. Cambridge, Massachusetts, Harvard University Press.

Oviedo y Valdés, G.F. de. 1535. Historia General y Natural de las Indias, Islas y Tierra-Firme. Sevilla, Juan Cromberger. 
Pais, P. 1945. História da Etiópia. Porto, Livraria Civilização.

Papavero, N. \& Teixeira, D.M. 2003. Os viajantes e a biogeografia. In: Morrone, J.J. \& Bousquets, J.L. (Ed.). Una perspectiva latinoamericana de la biogeografía. México, DF, Universidad Nacional Autónoma de México. p. 1-8.

Papavero, N., Pujol-Luz, J.R. \& Llorente-Bousquets, J. 2001. Historia de la biología comparada. Volume 4, De Descartes a Leibniz. México DF, Universidad Nacional Autónoma de México. (1628-1716).

Papavero, N.; D.M. Teixeira; Llorente-Bousquets, J. \& Hernández, A.B. 2004. Historia de la Biogeografia. El periodo preevolutivo. México, DF, Fondo de Cultura Económica. v. 1.

Papavero, N.; Teixeira, D.M. \& Chiquieri, A. 2011. As "Adnotationes" do Jesuíta Johann Breuer sobre a história natural da missão de Ibiapaba, Ceará (1789). Arquivos de Zoologia, São Paulo, 42(3): 133-159.

Paré, A. 1585. Les Oevvres d'Ambroise Paré, Conseiller, et Premier Chirvrgien du Roy. Paris, Gabriel Buon.

Pariset, E. 1862-1865. Histoire de la soie. Paris, Auguste Durand.

Pereira, D.P. 1892. Esmeraldo de situ orbis. Lisboa, Imprensa Nacional.

Piso, G. 1658. De Indiae Utriusque re naturali et medica Libri quatuordecim, Quorum contenta pagina sequens exhibet. Amstelaedami, Ludovicum et Danielem Elzevirios.

Plínio, o Velho. 1979-1984. Natural History. Cambridge, Massachusets, Harvard University Press \& William Heinemann.

Portmann, A. 1950. Le tube digestif. In: Grassé, P.P. (Ed.). Traité de Zoologie. Oiseaux. Paris, Masson et Cie. Éditeurs. v. 15, p. 270-284.

Prezia, B. 2009. Nossa Senhora da Conceição dos Guarulhos: a frustrada missão entre os Maromomi. In: Suess, P; Melià, B.; Beozzo, J.0.; Prezia, B.; Chamorro, G. \& Langer, P. Conversão dos cativos: povos indígenas e a missão jesuítica. São Bernardo do Campo, Nhanduti Editora. p. 91-109.

Purchas, S. 1614. Pvrchas his Pilgrimage. Or Relations of the World and the Religions observed in all Ages and Places discouered, from the Creation vnto this Present. London, William Stansby.

Purchas, S. 1625. Haklvytus Posthumus, or, Purchas his Pilgrimes. London, William Stansby.

Ramos, F.P. 2013. 0 apogeu e o declínio do ciclo das especiarias: 1500-1700. v. 2. A Carreira da Índia e a primazia da pimenta. Santo André, FPR/PEAH.

Randles, W.G.L. 1980. De la terre plate au globe terrestre. Une mutation épistémologique rapide (1480-1520). Paris, Librairie Armand Colin.

Ravenstein, E.G. 1901. The strange adventures of Andrew Battell of Leigh, in Angola and the adjoining regions. London, Hakluyt Society.

Rego, A. da S. 1953. Documentação para a história das missões do padroado português do Oriente. (1562-1565). Lisboa, Agência Geral do Ultramar. v. 9.

Rego, A. da S. \& Baxter, T.W. (Ed.). 1962. Documentos sobre os portugueses em Moçambique e na África Central 1497-1840. Lisboa, Centro de Estudos Históricos Ultramarinos. v. 1, p. 1497-1506.

Reimão, G.F. 1612. Roteiro da navegaçam e carreira da India, com seus caminhos, \& derrotas, sinaes, \& aguagei, \& differenças da agulha: tirado do que escreueo Vicente Rodrigues. \& Dioguo Afonso Pilotos antiguos. Agora nouamente acrescentado a viagem de Goa por dentro de são Lourenço, \& Moçambique, \& outras muitas cousas, \& aduertencias, por Guaspar Ferreira Reymão, caualeiro do habito de Sanctiago, \& Piloto mór destes Reynos de Portugal, por el Rey nosso senhor. Lisboa, Pedro Crasbeeck.

Reynolds, V. 1967. The apes. London, Cassell.

Rijksen, H.D. 1982. How to save the mysterious "man of the rainforest"? In: Boer, L.E.M. de (Ed.). The Orang Utan, its biology and conservation. Den Haag, DrW. Junk. p. 317-341.

Rijksen, H.D. \& Meijaard, E. 1999. Our vanishing relative: the status of wild orang-utans at the close of the twentieth century. Wageningen, Tropenbos Foundation.
Sá, A.B. de 1955. Documentação para a história das missões do padroado português do Oriente. (1563-1567). Lisboa, Agência Geral do Ultramar. Insulíndia. v. 3.

Schallei, G.B. 2010. The year of the gorilla. Chicago, University of Chicago Press.

Schoff, W.H. 1913. The Periplus of Hanno. A voyage of discovery down the West African coast. By a Carthaginian admiral of the fifth century b.C. The Greek text, with a translation. Philadelphia, Published by the Commercial Museum.

Schotti, G. 1662. Physica Curiosa, sive Mirabilia Naturis et Artis, libris XII. Herbipoli, Jobus Hertz.

Seixo, M.A. \& Carvalho, A. (Org.). 1996. A História Trágico-Marítima. Lisboa, Edições Cosmos.

Sick, H. 1984. Ornitologia brasileira: uma introdução. Brasília, Editora Universidade de Brasília.

Silva, I.F. da 1859. Diccionario bibliographico portuguez. Lisboa, Imprensa Nacional. v. 3, F-J.

Silva-Leite, R.; Roberto, I.J.; Loebmann, D.; Nascimento, T. da S. \& Silva, P. da C. 2010. Geographic distribution Eunectes murinus (Green Anaconda). Herpetological Review, 41(2): 244-245.

Sousa, G.S. de 1938. Tratado descriptivo do Brasil em 1587. São Paulo, Companhia Editora Nacional.

Southey, R. 1837. Lives of the British admirals, with an introductory view of the naval history of England Vol. 4. Robert Devereux, Sir Walter Raleigh. London, Longman.

Spencer, F. 1995. Pithekos to Pithecantropus: an abbreviated review of changing scientifc views of the relationship of the anthropoid apes to Homo. In: Corbey, R. \& Theunissen, B. (Ed.). Ape, man, apeman: changing views since 1600. Leiden, Leiden University. p. 13-27.

Staden, H. 1557. Warhaftige Historia vnd beschreibung eyner Landtschafft der Wilden, Nacketen, Grimmigen Menschfresser Leuthen, in der Newewelt America gelegen, vor vnd nach Christi geburt im Land zü Hessen vnbekant, biss vff disse ij. nechst vergangene jar, Da sie Hans Staden von Homberg auss Hessen durch den truck an tag gibt. Marpurg, Andres Kolben.

Stiles, C.W.\&Orleman, M.B. 1927. The nomenclature for man, the chimpanzee, the orang-utan, and the Barbary ape. Bulletin of the Hygienic Laboratory, Washington DC, 145: 1-66.

Teixeira, D.M. \& Papavero, N. 2010. 0 tráfico de primatas brasileiros nos séculos XVI e XVII. In: Pessôa, L.M., Tavares, W.C. \& Siciliano, S. (Org.). Mamíferos de Restingas e Manguezais do Brasil. Rio de Janeiro, Sociedade Brasileira de Mastozoologia \& Museu Nacional, UFRJ.

Thevet, A. 1557. Les singvlaritez de la France Antarctique, avtrement nommée Amerique: \& de plusieurs Terres \& Isles decounertes de nostre temps. Paris, Maurice de la Porte.

Thevet, A. 1575. Cosmographie Vniverselle d'André Thevet Cosmographe dv Roy. Paris, Pierre l'Huillier.

Thomaz, L.F. 1994. Estado da Índia. In: Albuquerque, L.M. (Org.). Dicionário de História dos Descobrimentos Portugueses. [Lisboa], Editora Caminho. v. 1, p. 388-395.

Toynbee, J.C.M. 1973. Animals in Roman life and art. London, Thames \& Hudson.

Tulpius, N. 1641. Observationvm medicarvm Libri Tres. Amstelredami, Lvdovicum Elzevirivm.

Tyson, E. 1699. Orang-outan, sive Homo sylvestris: Or, the anatomy of a pygmie compared with that of a monkey, an ape, and a man. To which is added, a Philological essay concerning the pygmies, the cynocephali, the satyrs, and sphinges of the ancients. Wherein it will appear that they are all either apes or monkeys, and not men, as formerly pretended. London, Thomas Bennet Daniel Brown.

Vasconcellos, S. de 1663. Chronica da Companhia de Jesv do Estado do Brasil:e do que obrarão sevs filhos nesta parte do Novo Mvndo. Lisboa, Officina de Henrique Valente de Oliveira. 
Vasconcelos, F. de 1941. As pinturas das Armadas da Índia e outras representações artísticas de navios portugueses do século XVI. Lisboa, [s.n.].

Vicente do Salvador. 1889. Historia do Brazil. Rio de Janeiro, Bibliotheca Nacional.

Vieira, A. 1660. Copia de hvma carta para El-Rey N. Senhor sobre as missoễ do Searâ, do Maranham, do Parà, \& do grande Rio das Almasónas. Lisboa, Officina de Henrique Valente de Oliueira.

Viotti, H.A. 1989. Obras completas do Padre José de Anchieta. Textos históricos. São Paulo, Edições Loyola. v. 9.

Viré, F. 1986. Kird. In: Bearman, P.; Bianchis, T.; Bosworth, C.E.; Donzel E. van. \& Heinrichs, W.P., Encyclopaedia of Islan. Khe - Mahi. Leiden, Brill. v. 5, p. 131-134.
Virgílio. 1999. Eclogues, Georgics, Aeneid. Cambridge, Mass., Harvard University Press.

Wendt, H. 1956. Auf Noahs Spuren: Die Entdeckung der Tiere. Hamm, C. Grote. White, T.H. (Ed.). 1954. The book of beasts: being a translation from a Latin bestiary of the twelfth century. New York, G.T. Putnam.

Wicki, J. 1960. Primeira parte da historia dos religiosos da Companhia de Jesus, e o que fizeram com a divina graça na conversão dos infiéis a nossa sancta fe catholica nos reinos e provincias da India Oriental. Composta pello P.e Sebastiam Gonçalves religioso da mesma Companhia, português, natural de Ponte de Lima. Coimbra, Atlântida.

Yule, H. 1903. The book of Ser Marco Polo the Venetian, concerning the kingdoms and marvells of the East. London, John Murray. 
ANEXO 1

Reprodução do texto de Gaspar Afonso sobre a viagem da nau

"São Francisco" (Conforme B.G. de Brito, 1735-1736)

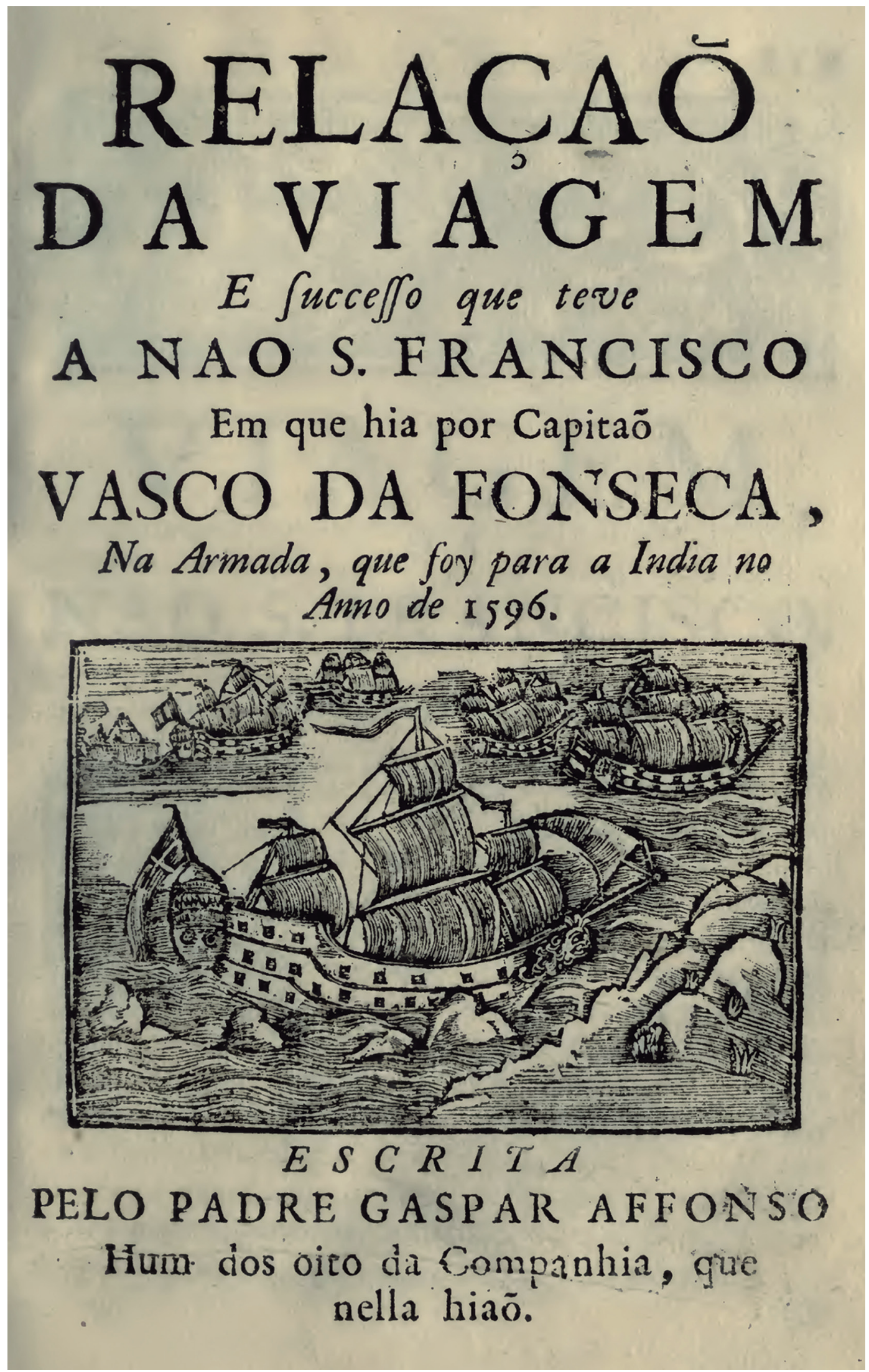




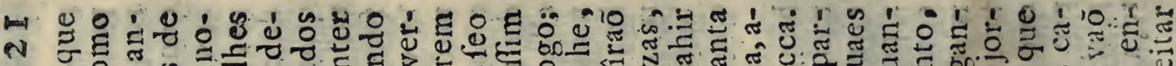

$m$ u 00.0 .0 o 0 .

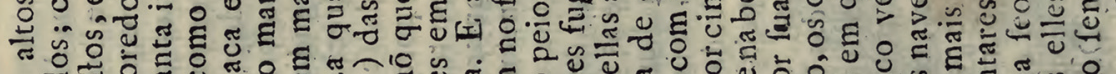

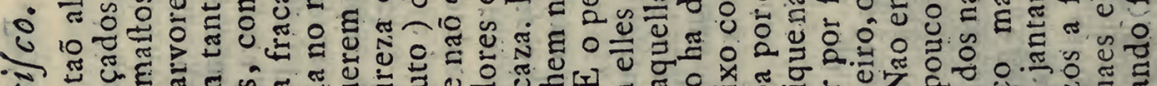

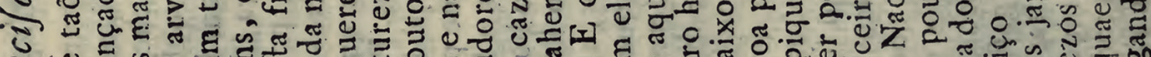

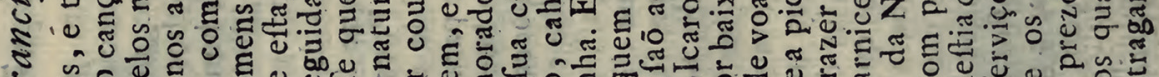

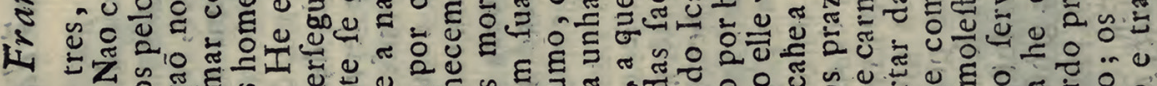
๘ 8 过 \& * \& ए \% ङ

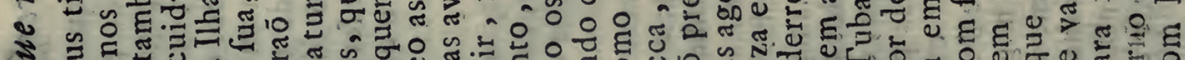
o 若

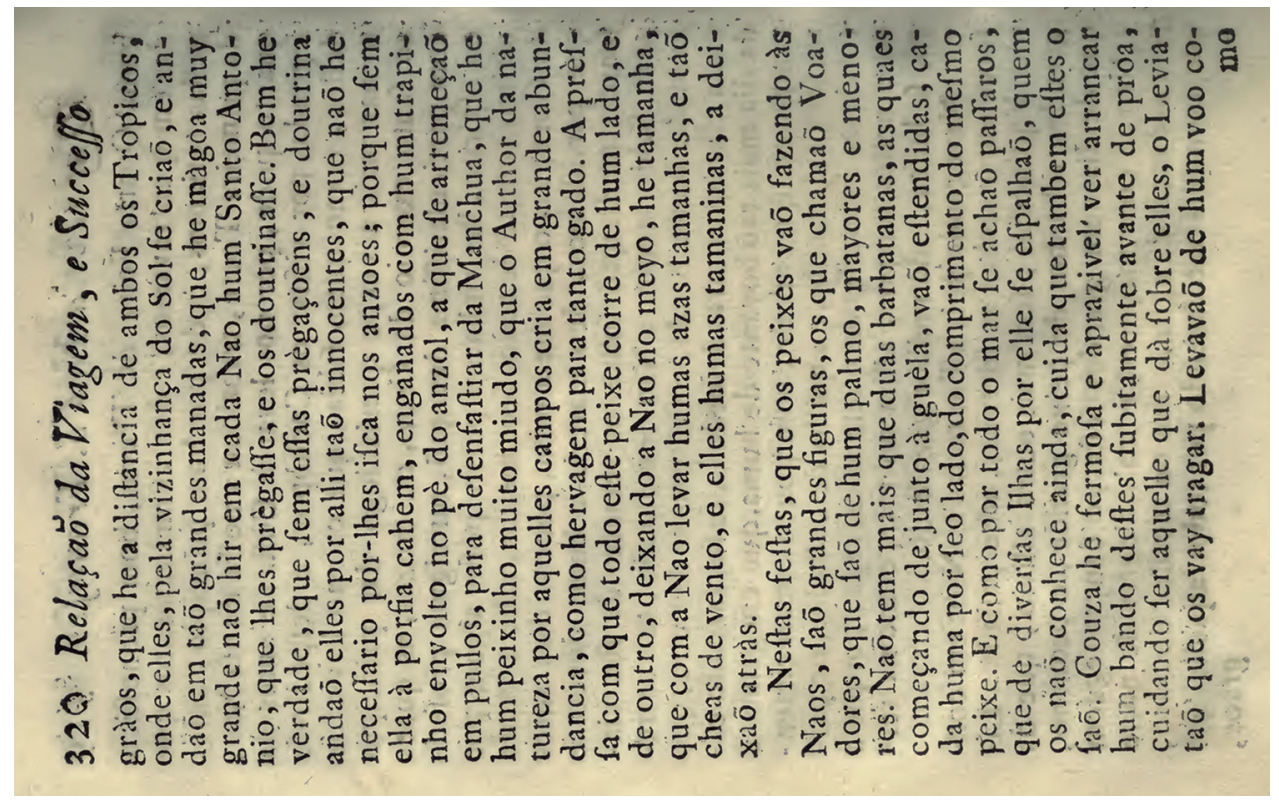

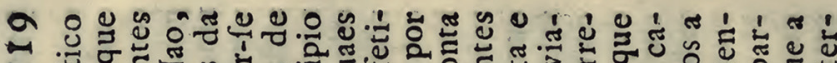

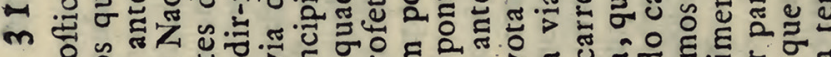

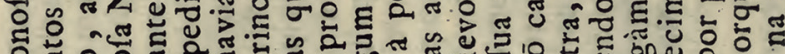

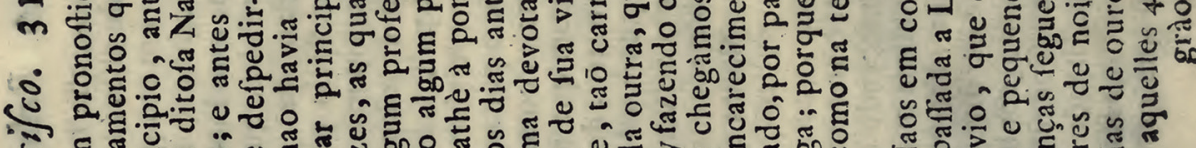

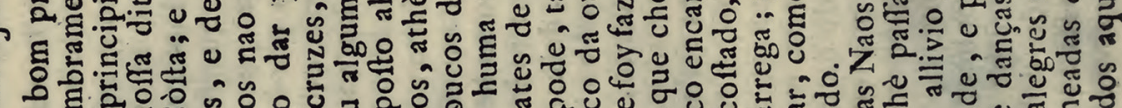

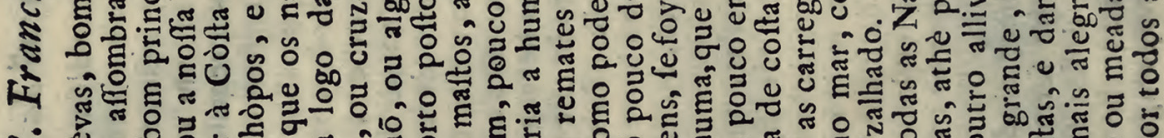

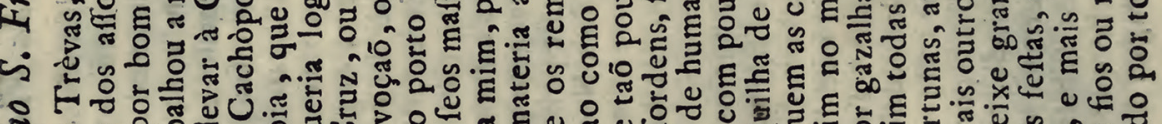
Z ङ

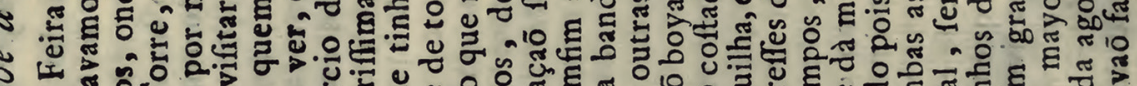

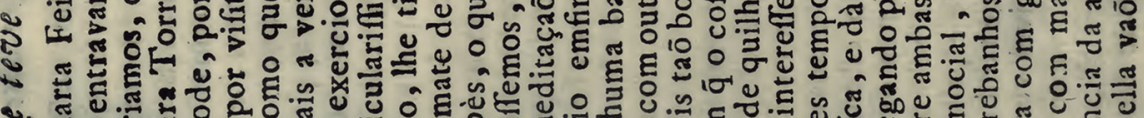
\) O 1 E

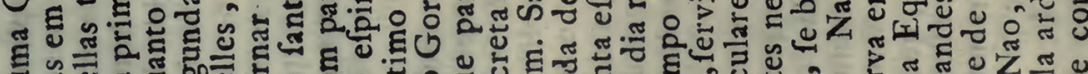

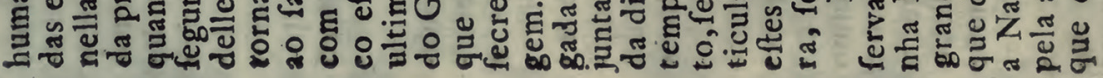




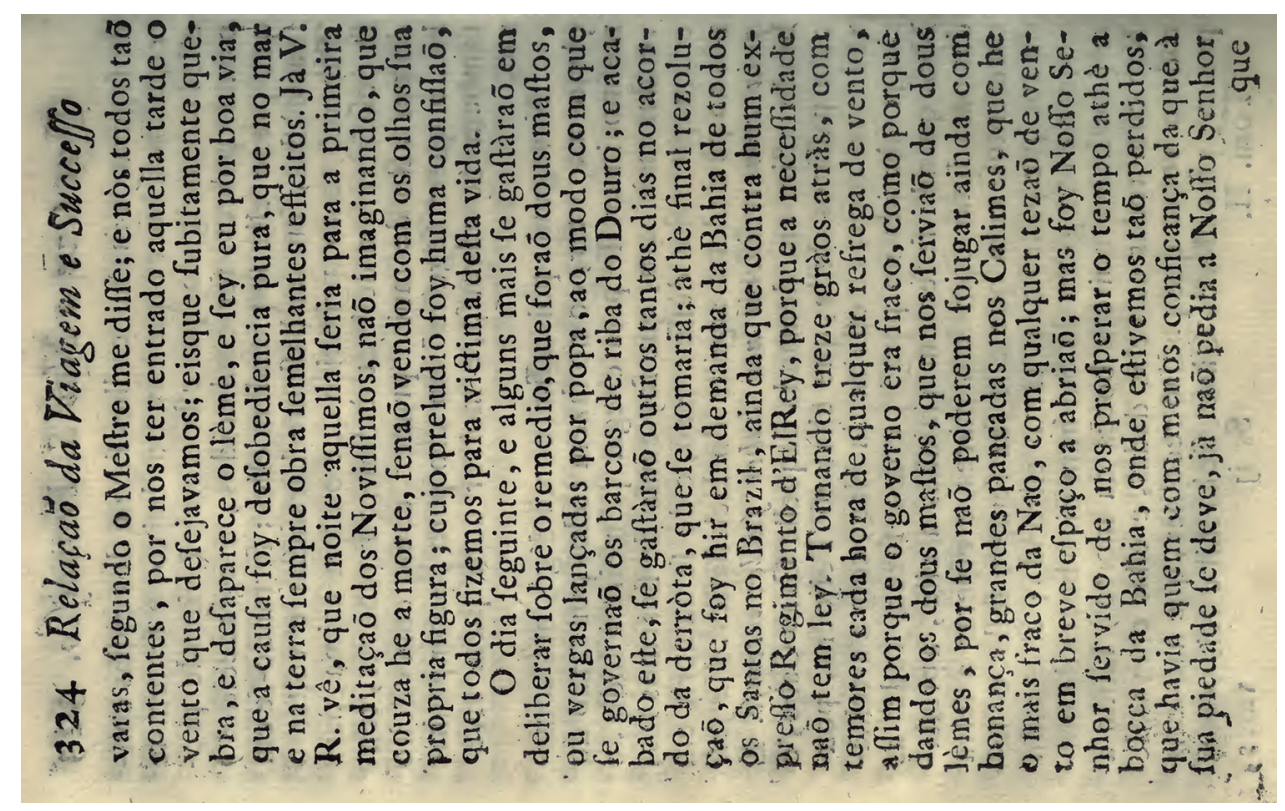

ल

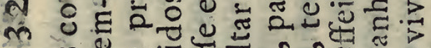

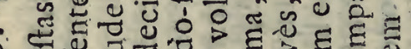

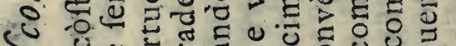
ए人

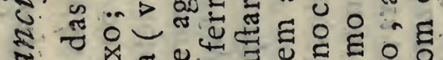

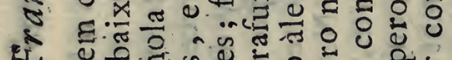

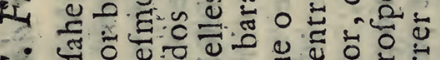
ن. ज़ ह

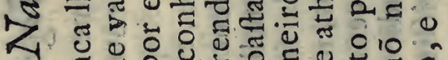
- E

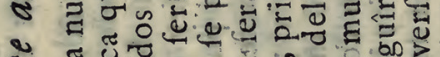
ट $\Xi \tilde{U}: 00 \%$

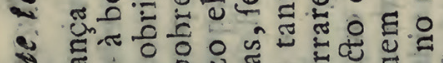
(1)

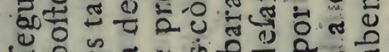
ษ

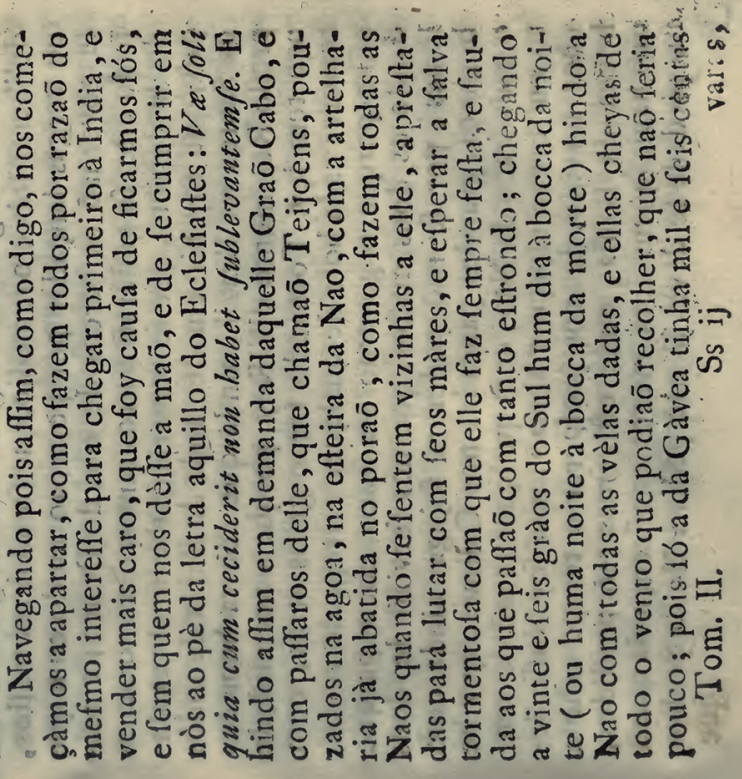

늘 की \& 心 0 o

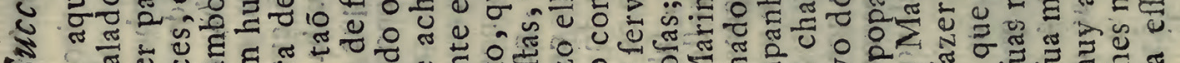
ज 0 त

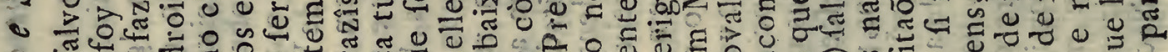
इ

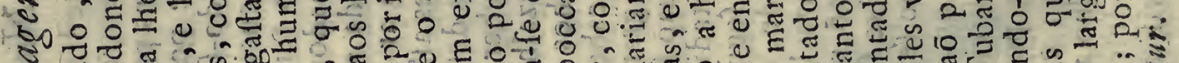
- की 0 औ N

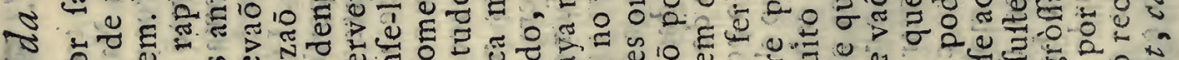
ग 0 क 5 U 늘

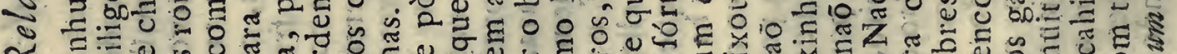
र

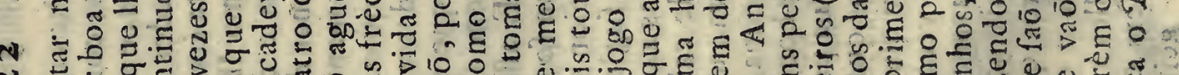

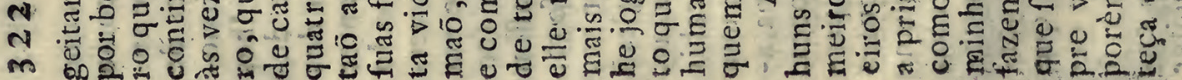



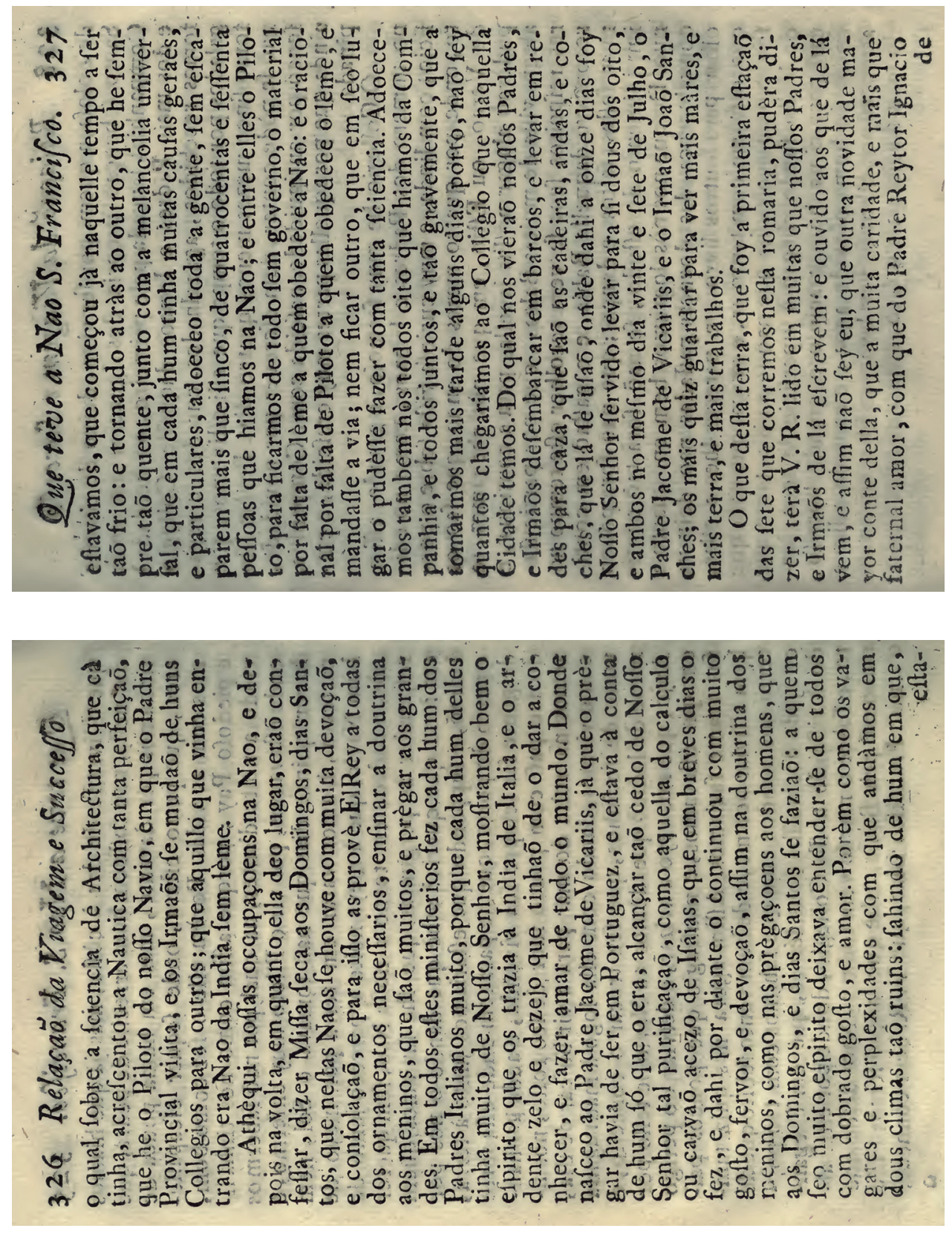

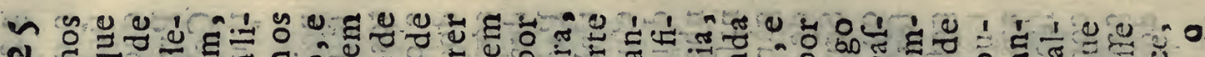

n

สำ 10 У

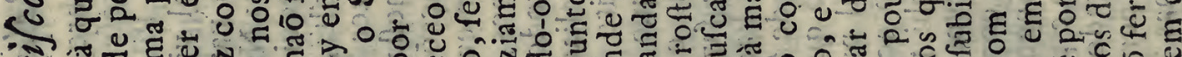

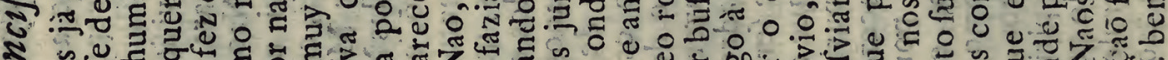

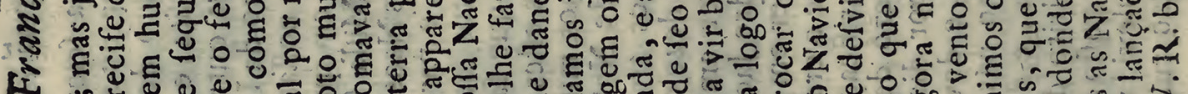
A $\ldots$ \%

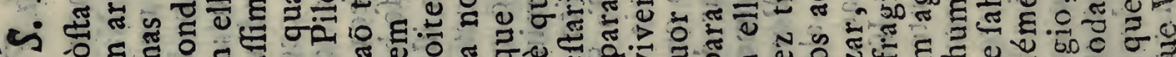

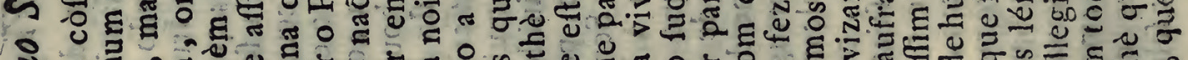

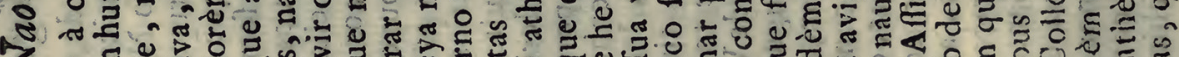

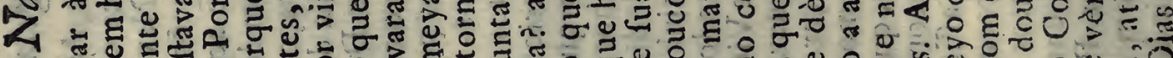

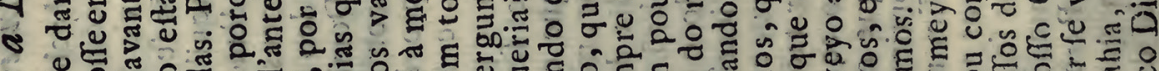

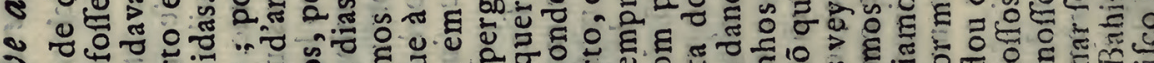

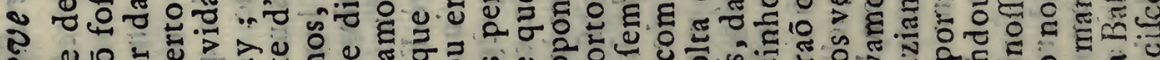
\& जٓ

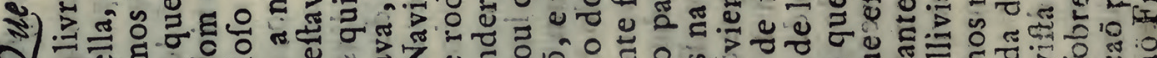
○ 先

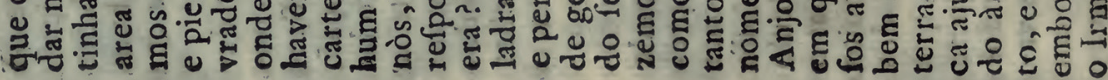




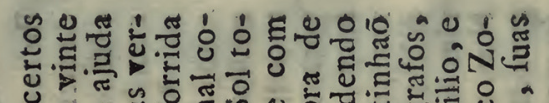

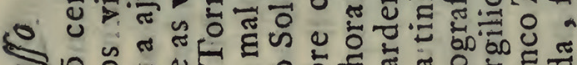

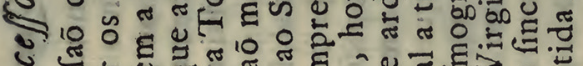

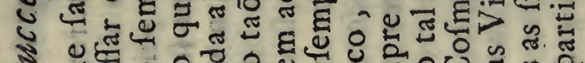
भ (c) 10 है ล ¿

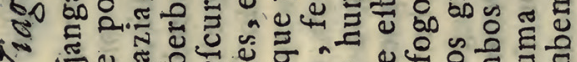
N ㅇ ह

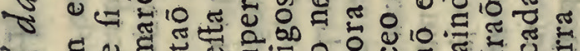

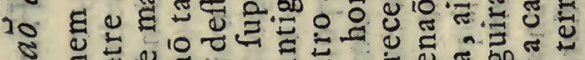
फ ๘

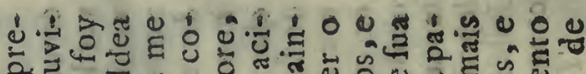

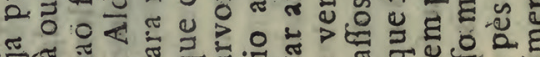
ปี่

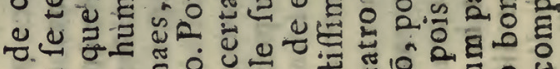
ชับ

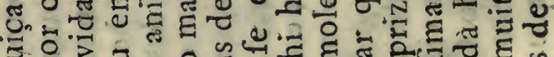

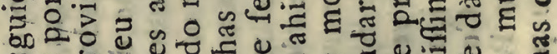

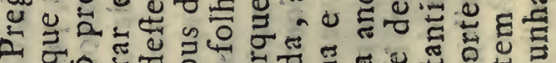
न

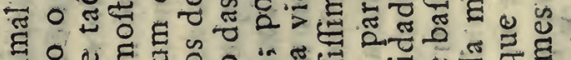

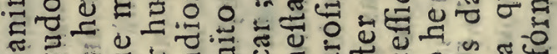

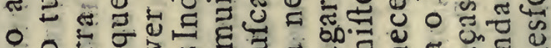

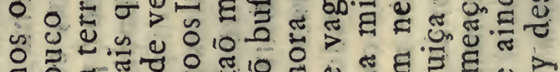

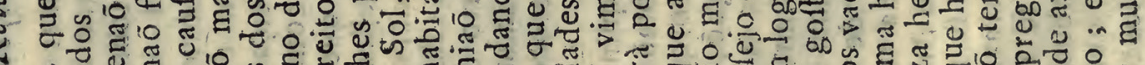

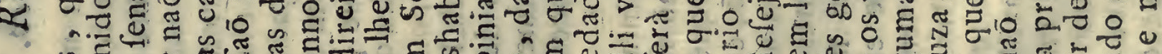

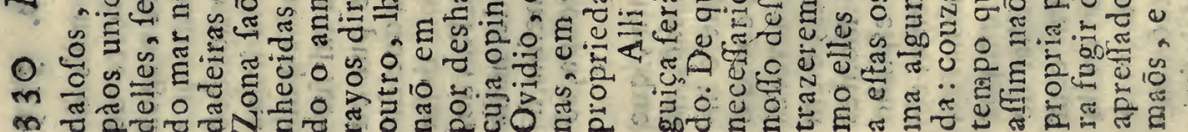

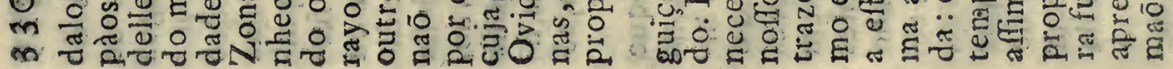

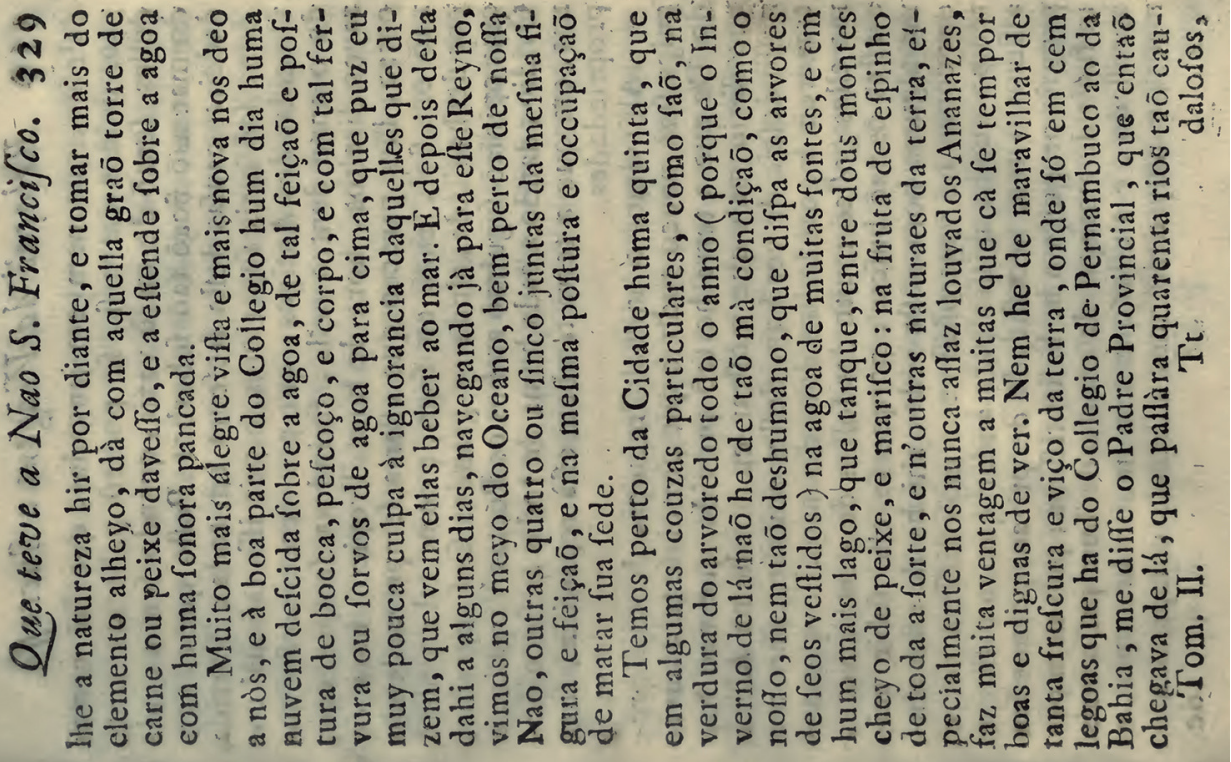

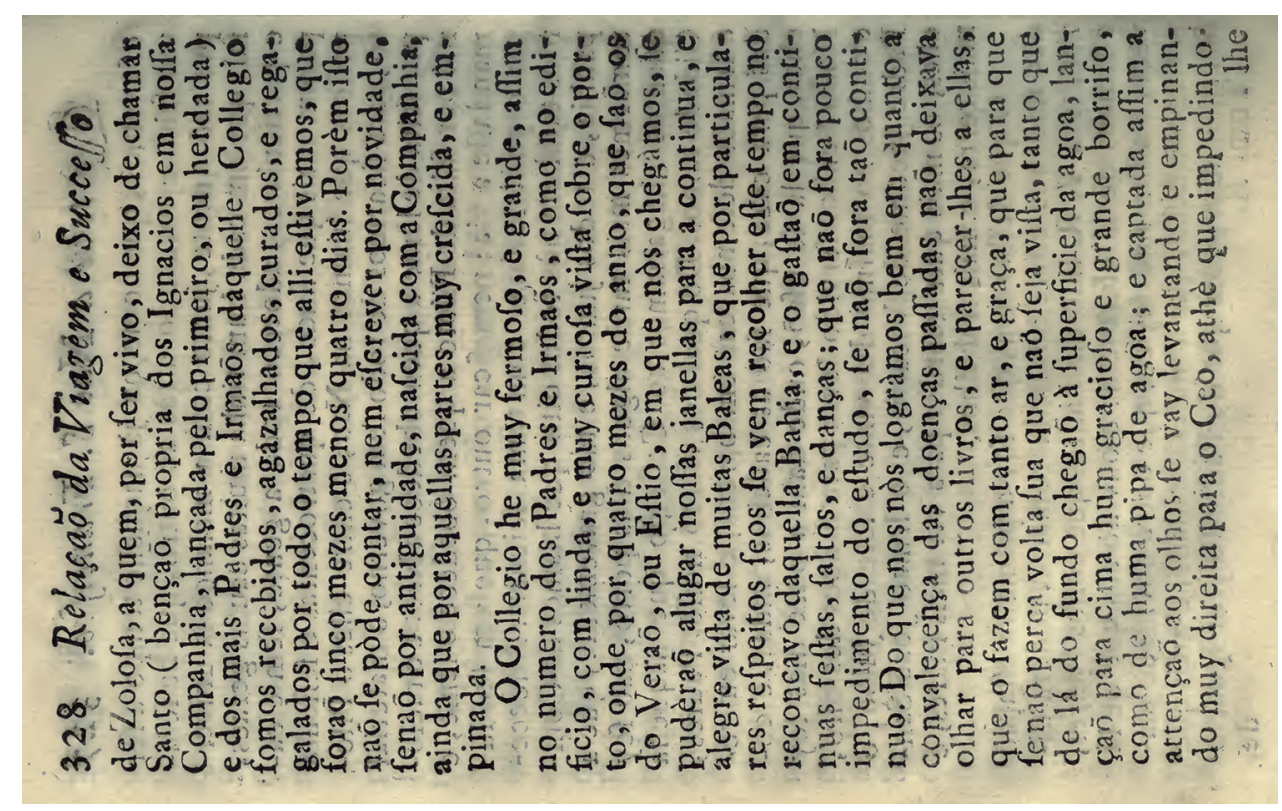



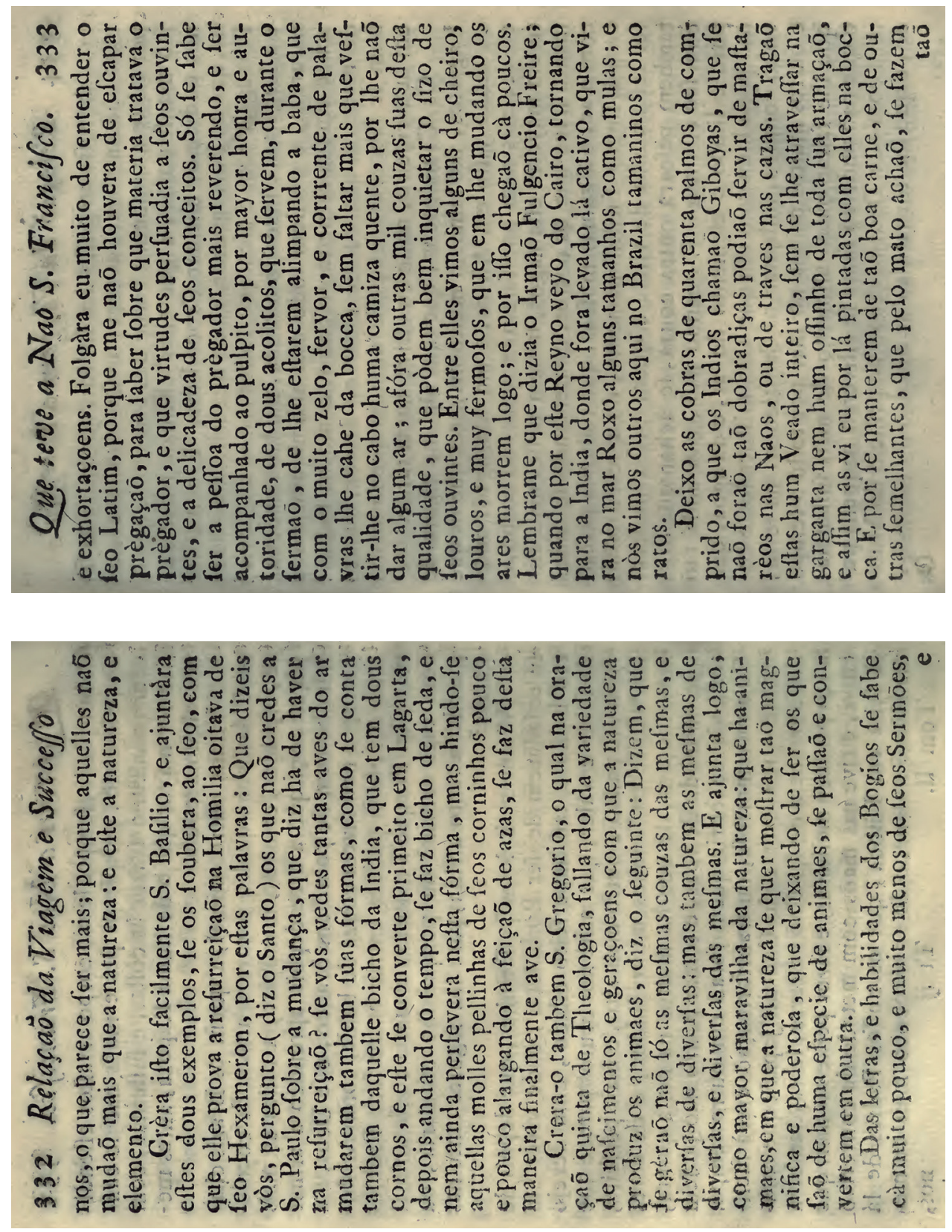

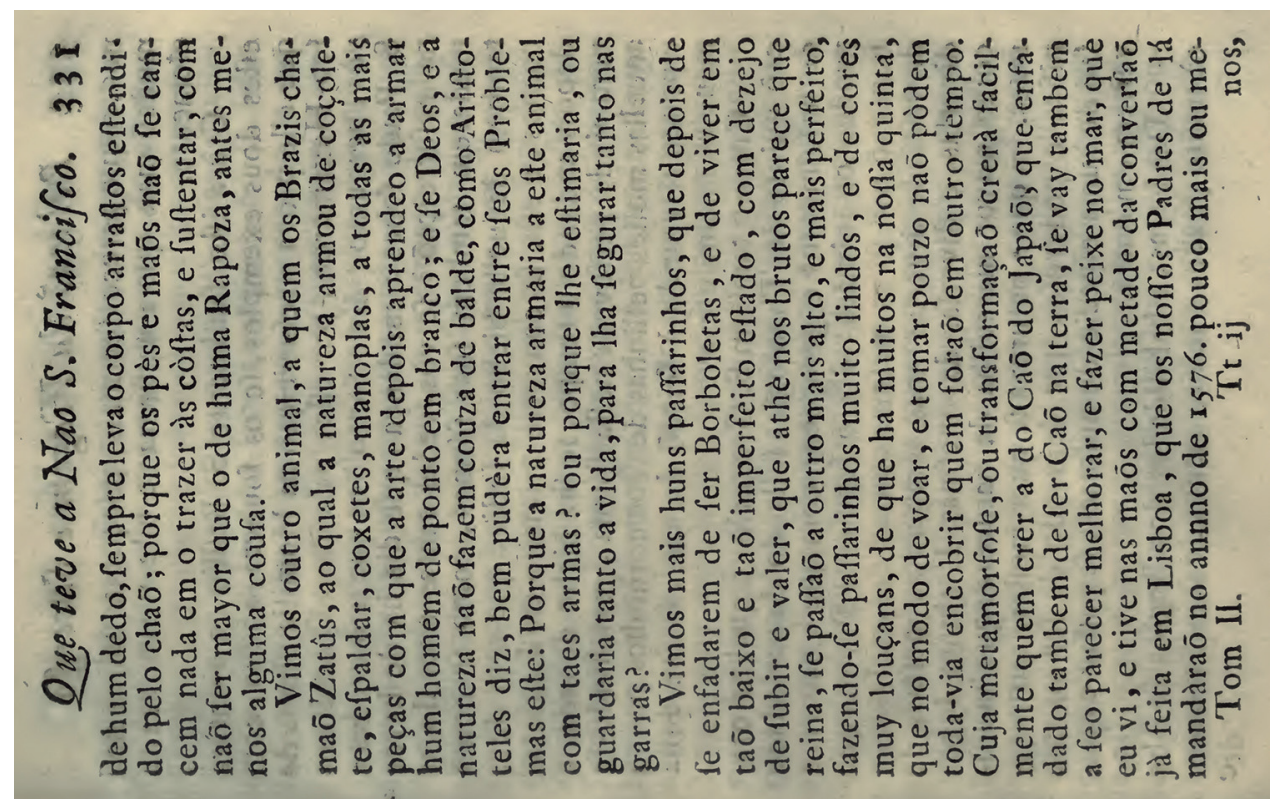



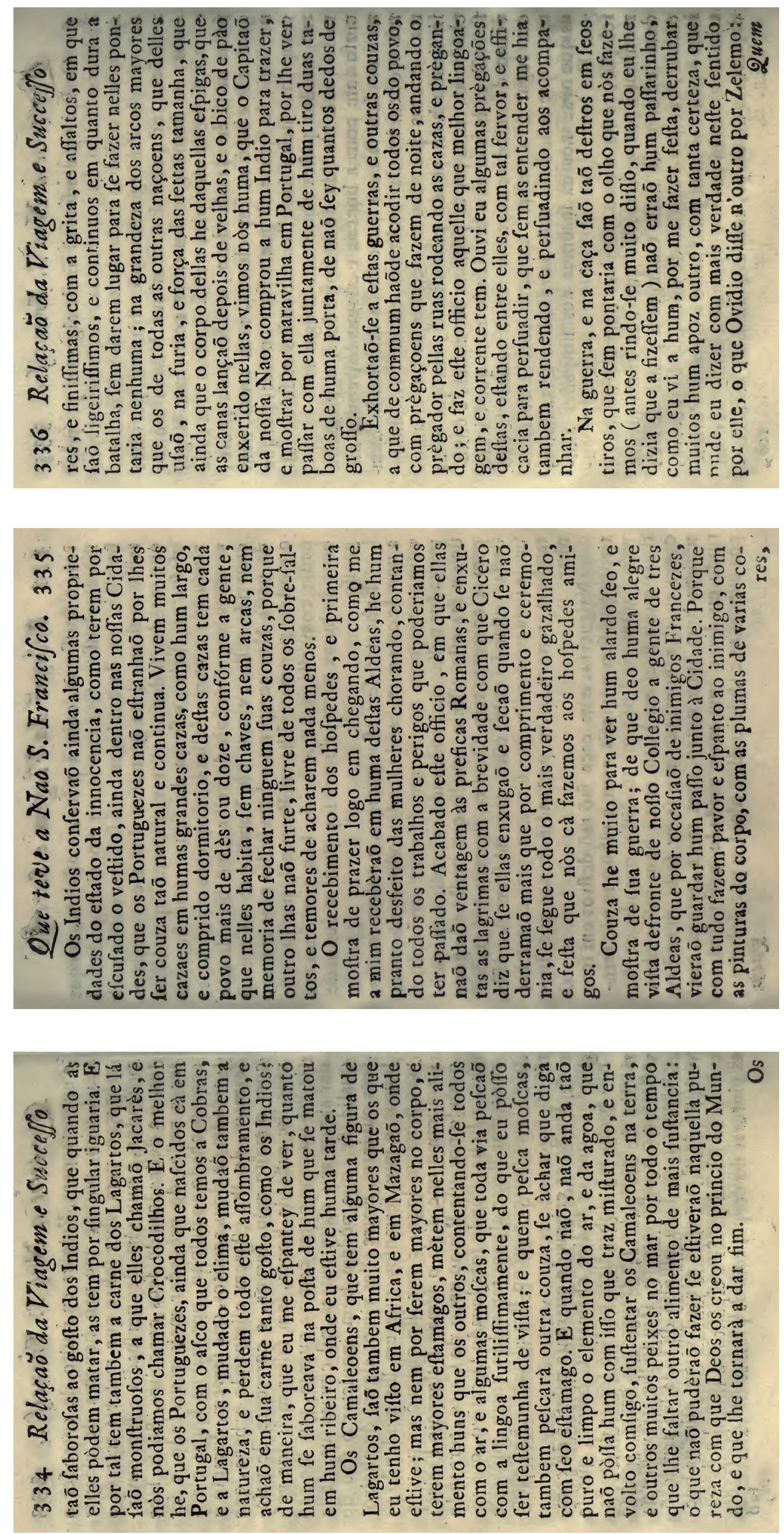

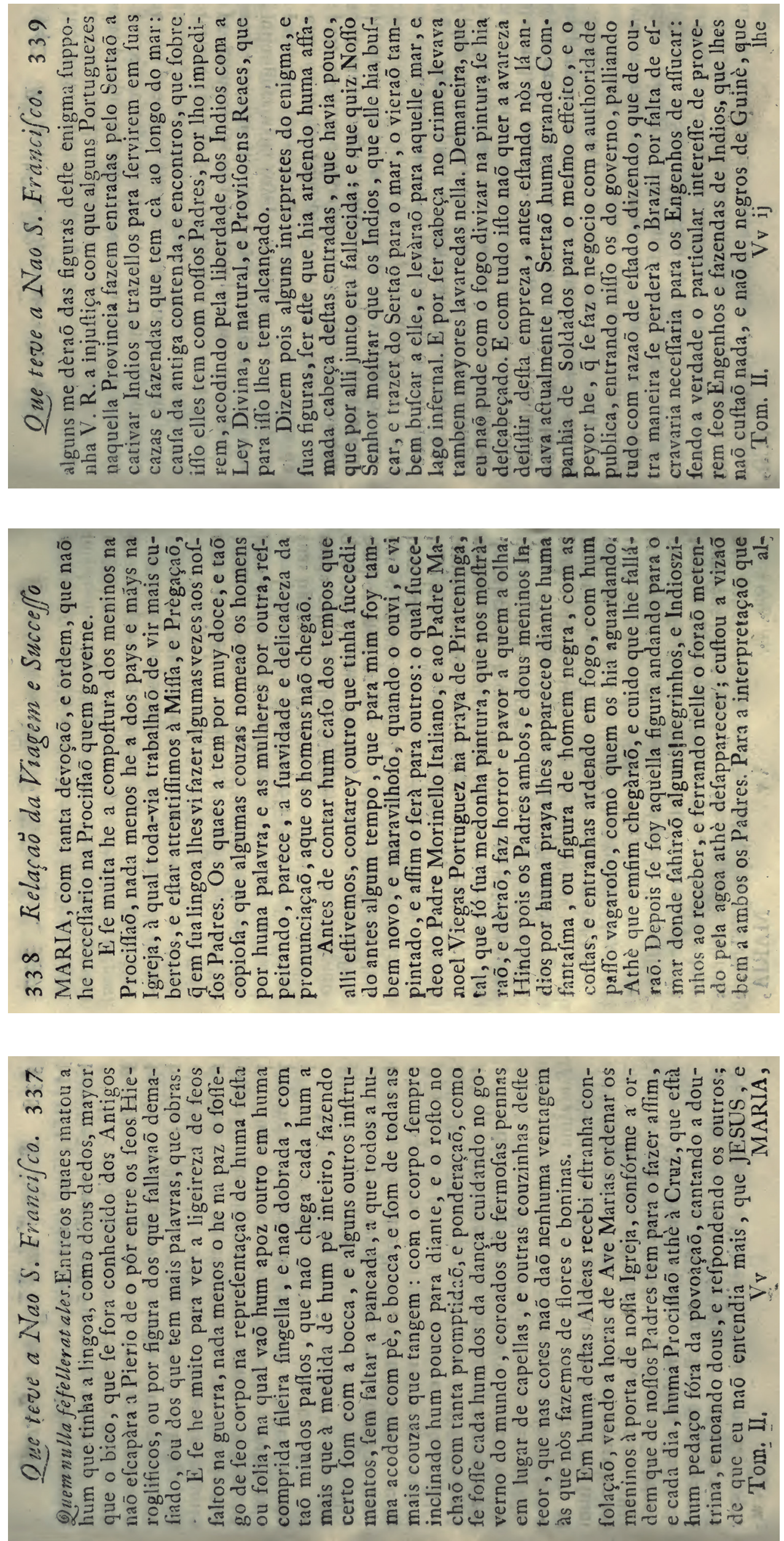


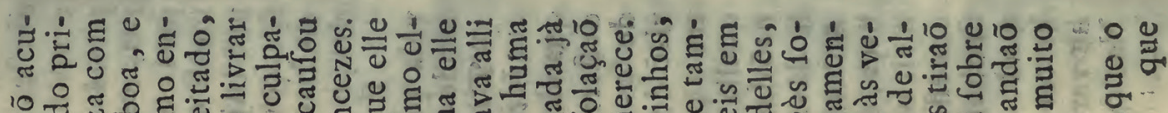

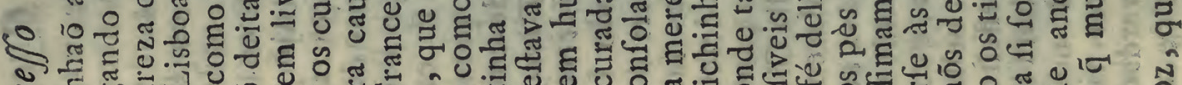
ษ ऊँ 于 ๘

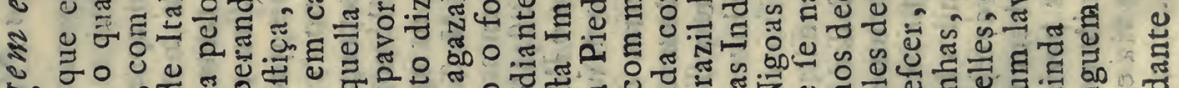
ธo б0u \%

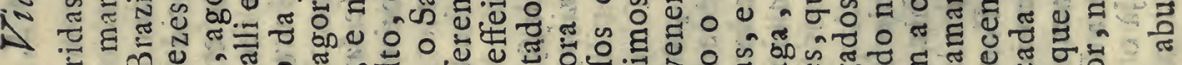
$\checkmark$ य 0 \% 0

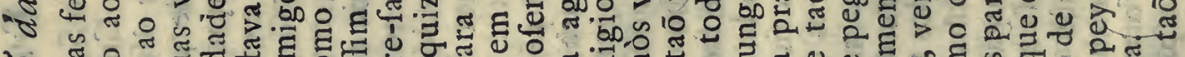

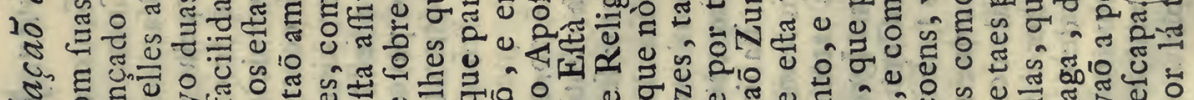
¿

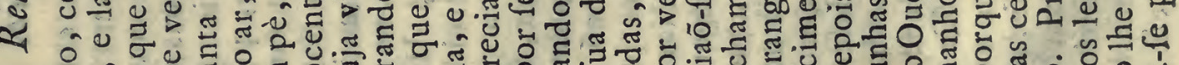

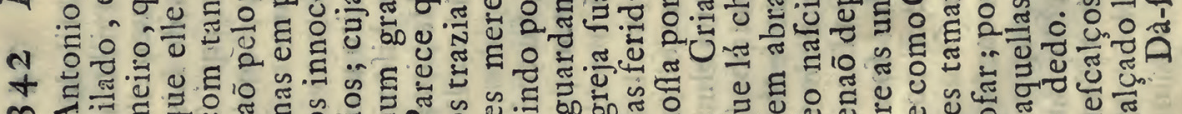

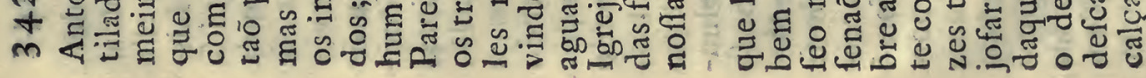

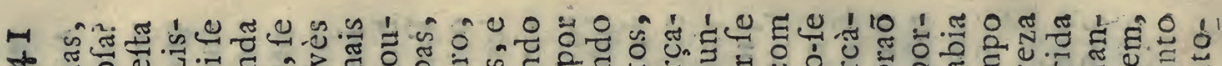

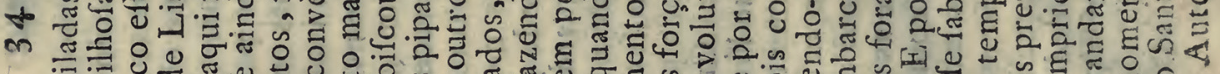

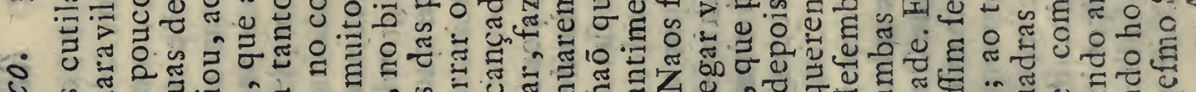

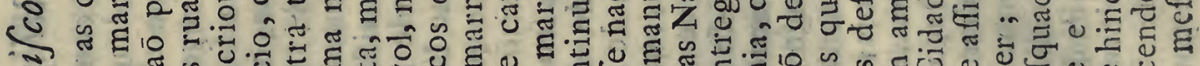

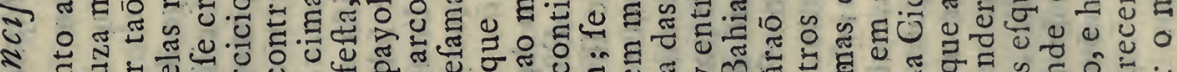

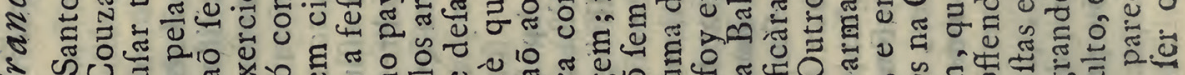
ผ का ن

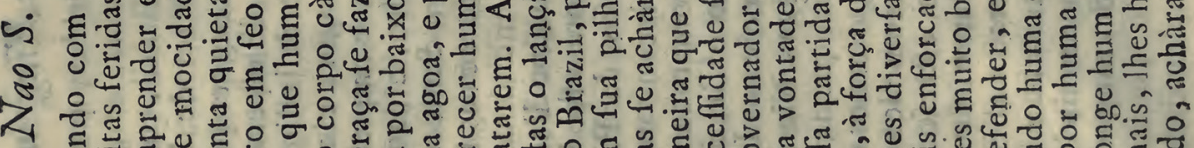

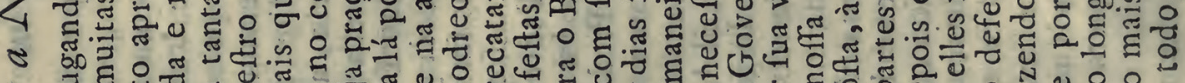
.

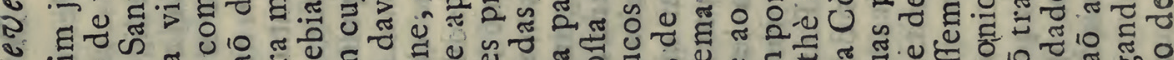

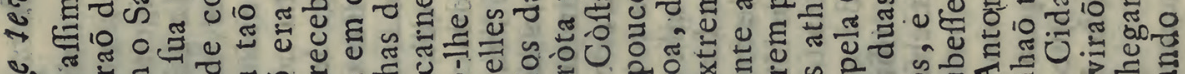

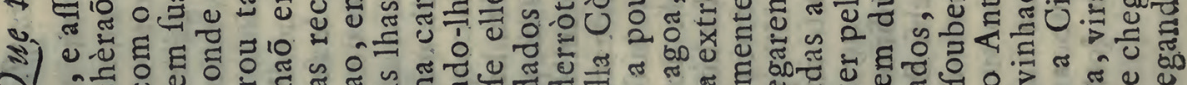
O ๘ँ

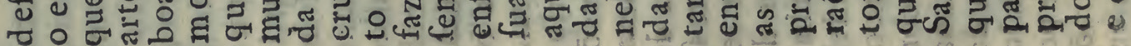

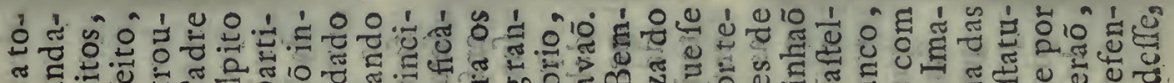

ส 욱. ¿

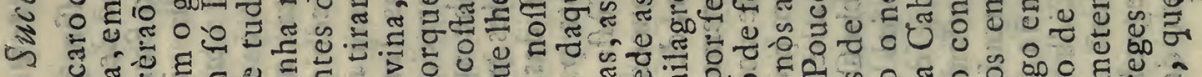
ชิ sัง ك А चٓ

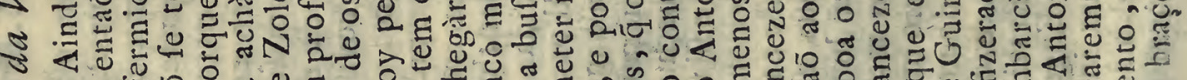

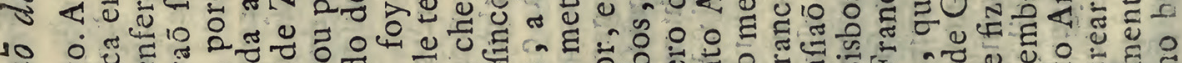

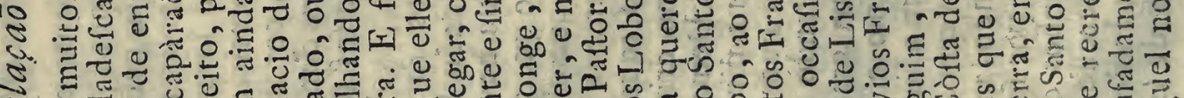
¿ 10 뉸 « 迈

o U⿺尢丶万

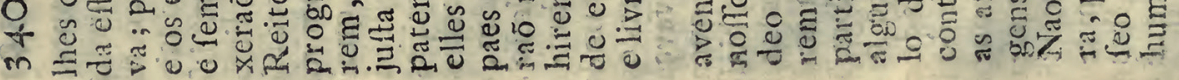




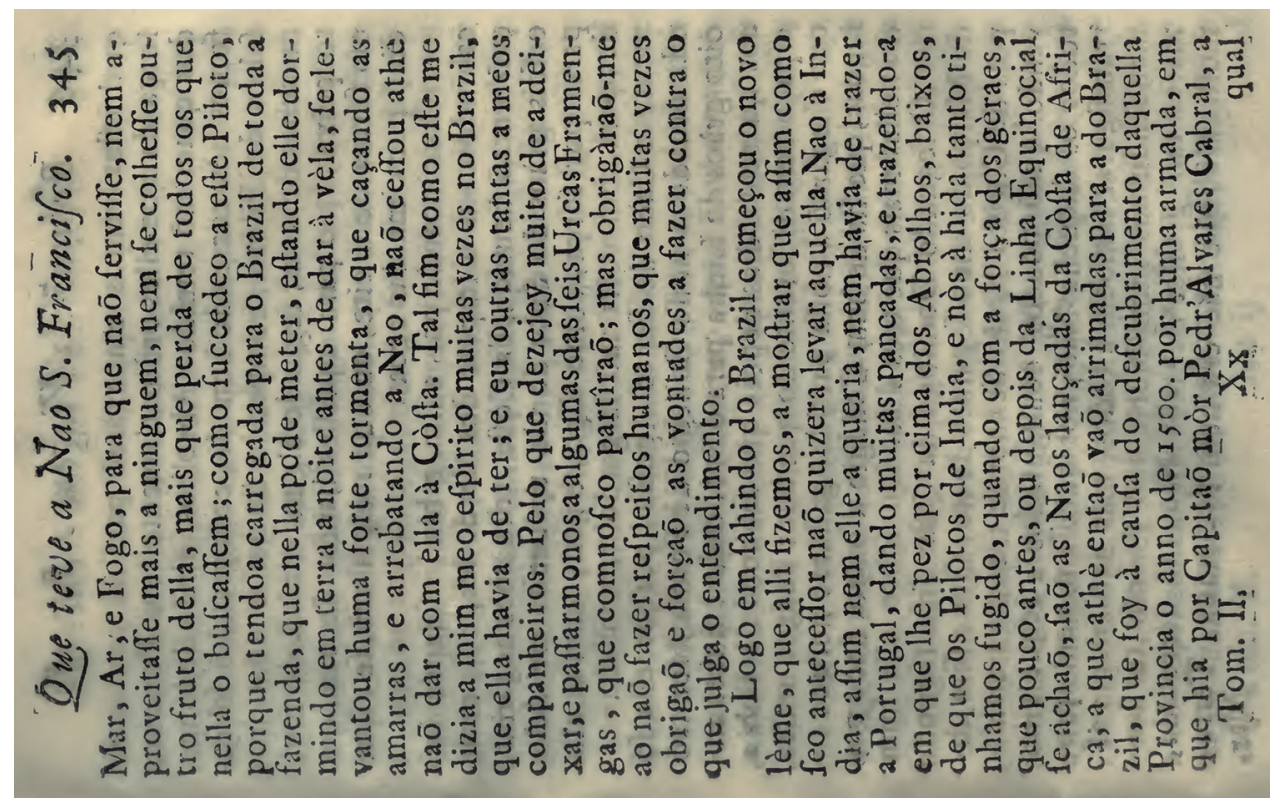

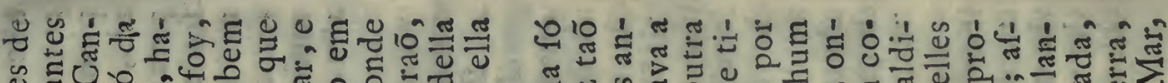
$\circ$ 过 记

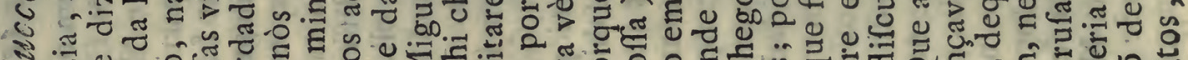

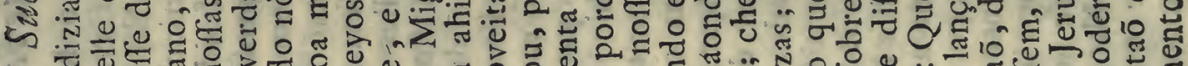

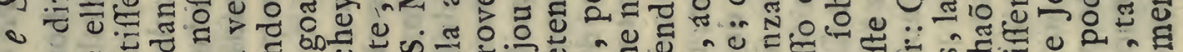
E 5

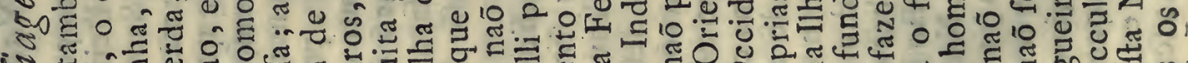
N

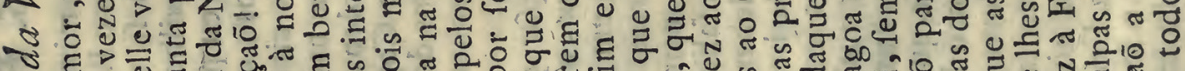
3o

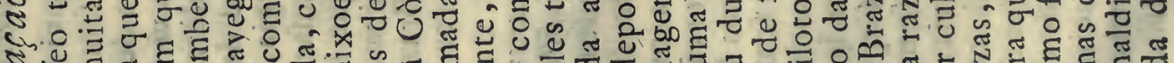
뉸 हE

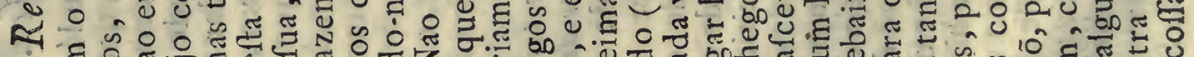

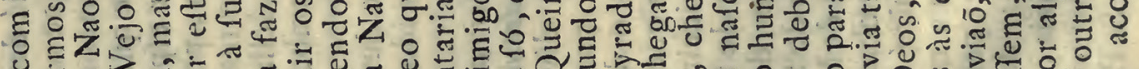
$+0$

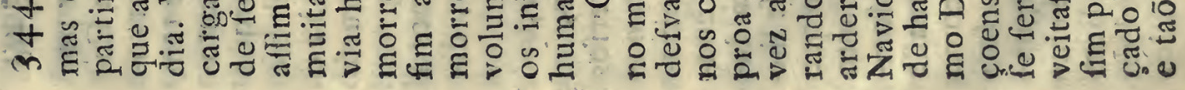

\begin{tabular}{|c|c|}
\hline 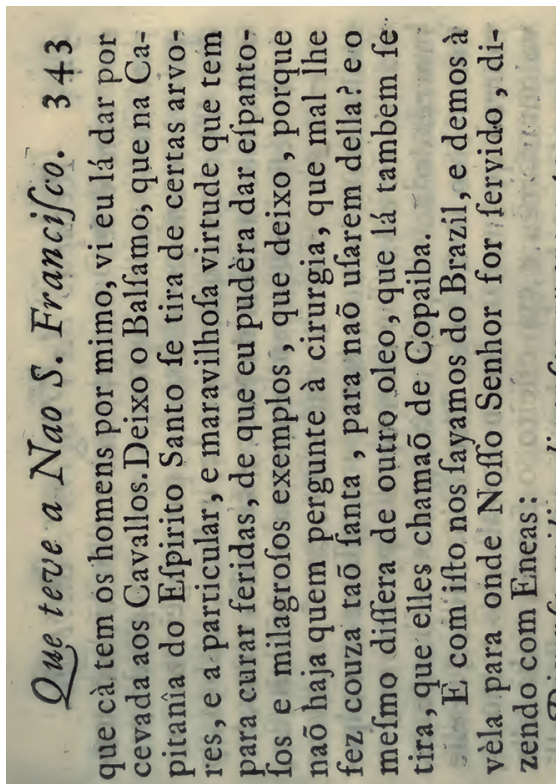 & 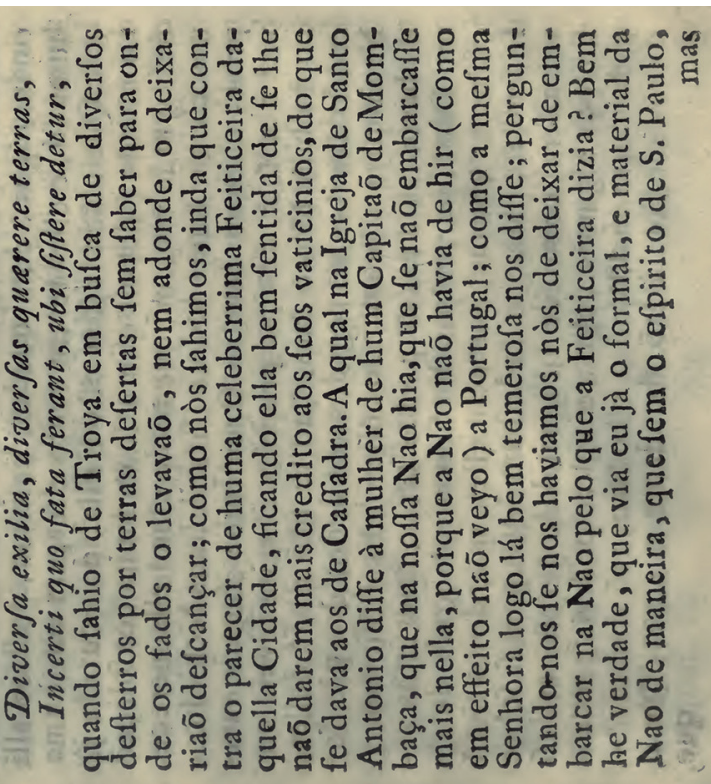 \\
\hline
\end{tabular}



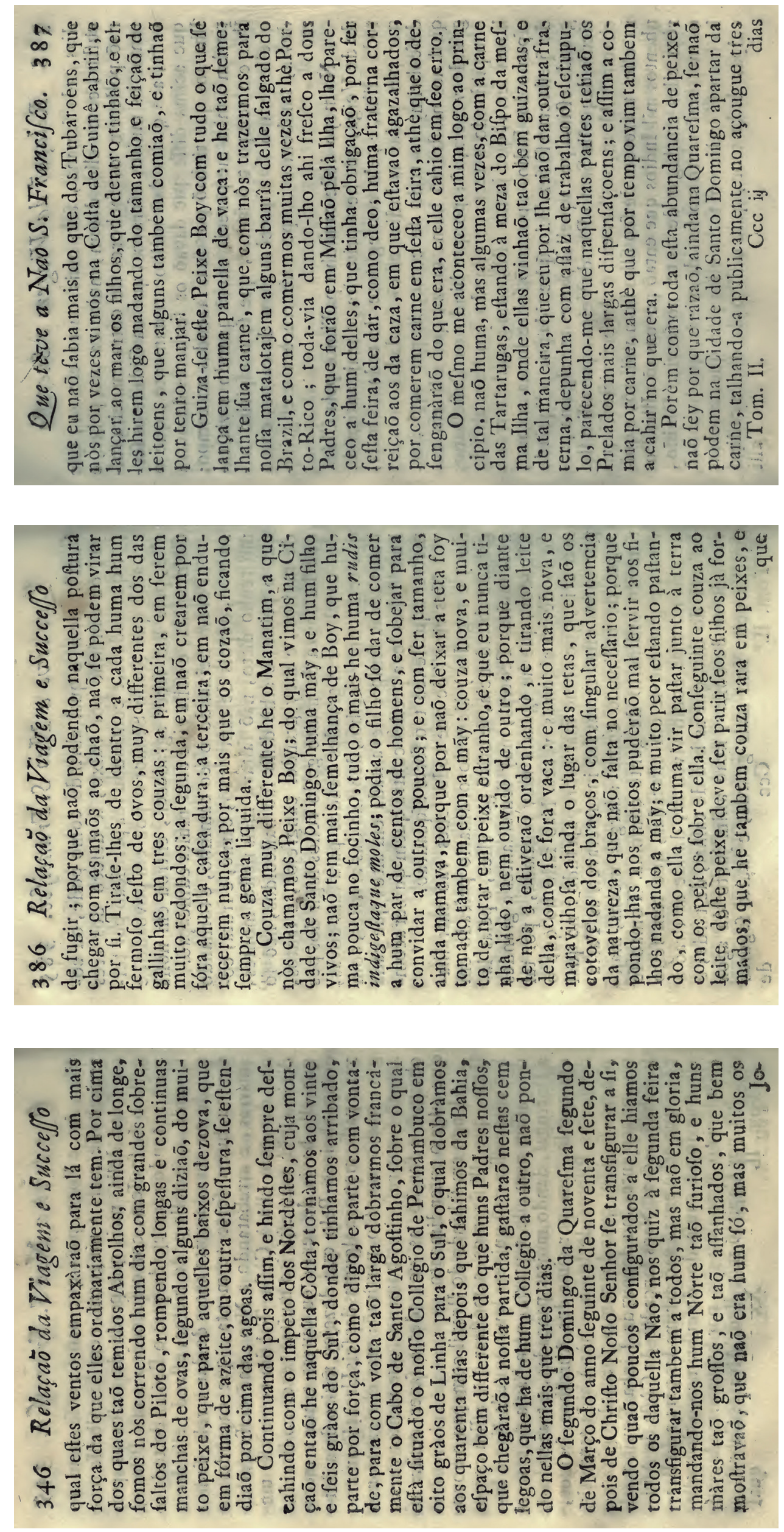